\title{
Chapter 18. Stable isotope paleoecology of the Baynunah Formation
}

Kevin T. Uno ${ }^{1}$ and Faysal Bibi ${ }^{2}$

Author affiliations:

1) Division of Biology and Paleo Environment, Lamont-Doherty Earth Observatory of Columbia University, Palisades, New York, 10964 USA kevinuno@1deo.columbia.edu

2) Museum für Naturkunde, Leibniz Institute for Evolution and Biodiversity Science, Invalidenstrasse 43, 10115 Berlin, Germany 


\begin{abstract}
The Baynunah Formation contains the only known late Miocene terrestrial fossils from the Arabian Peninsula. Based on renewed field work since 2002, we present paleoenvironmental and dietary reconstructions from carbon isotope data from plant wax biomarkers and carbon and oxygen isotope data from fossil tooth enamel in combination with previously published fossil tooth enamel and pedogenic carbonate isotope data. The organic and isotopic data indicate that the highly seasonal ecosystem supported a herbivore community that relied heavily on $\mathrm{C}_{4}$ vegetation. Carbon isotope and molecular abundance data from $n$-alkanes indicate mostly mixed $\mathrm{C}_{3}-\mathrm{C}_{4}$ and $\mathrm{C}_{4}$-dominated ecosystems. Carbon isotope data from fossil teeth indicate a range of $\mathrm{C}_{3}$, mixed $\mathrm{C}_{3}-\mathrm{C}_{4}$, and $\mathrm{C}_{4}$ diets, with suids, deinotherids, and rhinocerotids browsing, and bovids, elephantids, and equids mixed feeding to grazing. Hippopotamids show the most positive carbon and most negative oxygen values, with narrow ranges indicating year-round grazing and semiaquatic habits. The Baynunah sivatheres represent the earliest evidence for a $\mathrm{C}_{4}$-dominanted diet among giraffids. Equid intratooth oxygen isotope profiles indicate a highly seasonal hydroclimate regime, reflecting strong monsoonal conditions with a single rainy season. Corresponding carbon profiles record large seasonal changes in equid diets, with mainly grazing in the wet season and increased browsing in the dry season. Baynunah ecosystems comprised savanna habitats (woody grasslands) with the proboscidean trackway site of Mleisa 1 likely being a seasonally flooded $\mathrm{C}_{4}$ grassland.
\end{abstract}

Running head: Stable isotope paleoecology 


\section{Introduction}

The Baynunah Formation contains the only known terrestrial vertebrate fossils from the late Miocene of the Arabian Peninsula. Most outcrops of the Baynunah Formation are jebels that rise above the flat landscapes of western Abu Dhabi Emirate (Fig. 18.1). The Baynunah Formation is several tens of meters thick in most places and exceeds $50 \mathrm{~m}$ at the type section at Jebel Barakah (Whybrow et al. 1999). The lower part of the formation is comprised primarily of fossil bearing fluvial channel deposits and paleosols, whereas the upper part has some carbonate beds and several packages of finer grained sediments that suggest small lakes or seasonally flooded areas

(fig. 3.2 in Schuster this volume). Channel clasts in the lower part of the formation are commonly reworked, intraformational pedogenic carbonates or rarely, oncolites. Root casts are a common feature of the paleosols and sandy channel deposits. More detailed descriptions of the sedimentology, fluvial architecture, and depositional environments are found in the first

Baynunah volume (Friend 1999; Whybrow et al. 1999) and an updated synthesis with new observations is given by Schuster (this volume).

Like much of the Arabian Peninsula, the climate of Abu Dhabi is hyperarid, with mean annual temperature in excess of $27^{\circ} \mathrm{C}$ and annual precipitation of less than $100 \mathrm{~mm}$ per year. The harsh environment today is a stark contrast to what the Baynunah fossil and sedimentary evidence indicates: lush, verdant habitats supported by a perennial braided river system that was home to many large mammals, including ancient elephants, horses, hippos, antelopes, giraffes, rhinos, and pigs, among other mammals, reptiles, fishes, birds, and invertebrates (Whybrow and Hill 1999; Bibi et al. this volume-a).

FIG. 18.1 NEAR HERE. Width $=1.5$ columns. 
The fossils of the Baynunah Formation were likely known to locals for centuries, but the first written records in English come from petroleum industry reports from the late 1940s and early 1950s (Hill et al. 1999). These early reports eventually led to a collaborative research project on the geology and fauna of the Baynunah Formation in the 1980s-1990s, which culminated in the publication of the first research volume (Whybrow and Hill 1999). Fieldwork in the Baynunah Formation resumed in 2002 and a wealth of new fossil material has been recovered since then. The amount of new fossil material and sites warrants a fresh look at the Baynunah material and its paleoecological context. Also, since 1999, many new records have been published that document regional vegetation, dietary, and faunal change across Neogene sites of the Old World (Badgley et al. 2008; Barry et al. 2002; Behrensmeyer et al. 2007; Feakins et al. 2005; Leakey and Harris 2003; Polissar et al. 2019; Uno et al. 2011; Uno et al. 2016a). The paleoecology of Baynunah has therefore much to contribute to the global context of late Neogene ecosystem change, characterized by the expansion of $\mathrm{C}_{4}$ grasslands and mammalian dietary shifts. Furthermore, new analytical techniques, such as compound specific isotope analysis of plant waxes, can now contribute additional information. Stable isotope analyses of biomarkers (plant waxes) and biominerals (tooth enamel) are now well-established and widely used methods to reconstruct mammal diets and terrestrial vegetation.

In this chapter, we use geochemical analyses of plant wax biomarkers and fossil tooth enamel to reconstruct the vegetation, hydroclimate, and mammalian diets of the Baynunah Formation. Carbon isotope ratios of plant wax biomarkers extracted from sediments are used to reconstruct the proportion of $\mathrm{C}_{3}$ to $\mathrm{C}_{4}$ vegetation. We reconstruct the diets of eight herbivore lineages using carbon isotope ratios in fossil tooth enamel and evaluate the dietary structure of 
the herbivore community. Oxygen isotope ratios in tooth enamel provide additional information on dietary niche partitioning and environmental aridity. We assess the seasonality of vegetation, precipitation, and equid diets from intratooth isotope profiles of cheek teeth. Environmental and dietary reconstructions incorporate previously published stable isotope data from pedogenic carbonate and fossil tooth enamel data from Kingston (1999). Together, these data support previous interpretations and also give new insight into the paleoecology of the Baynunah. To provide a more global perspective, we compare the Baynunah tooth enamel and pedogenic carbonate isotope data to isotope data from other major late Miocene fossil localities in Africa and South Asia.

\section{Materials and Methods}

\subsection{Materials}

The material used in this study includes fossil teeth that were sampled in 2011 and 2014. All fossil localities of the Baynunah Formation are described in detail in Chapter 2 (Bibi et al. this volume-b). This study considers both new data as well as that presented by Kingston (1999). All sites from which data are known are shown in Fig. 18.1. In cases where samples come from unknown or unnamed localities at known site areas, these are denoted as 'UL'.

Baynunah Formation sediments analyzed for compound specific carbon isotope ratios of plant waxes were collected in December 2014 from fine grained deposits, typically brown or green silts or silty clays, at Hamra (HMR 5), Ruwais (RUW SE), Kihal (KIH 2), and Mleisa (MLS 1). GPS coordinates are given in Table 18.3. Newly sampled fossil teeth come from surface and in situ finds at Jebel Barakah (JBR UL), Shuwaihat (SHU 1, 2, and 4), Hamra (HMR 1, 2, 3, 5 and 6), Jebel Dhanna (JDH 4), Ras Dubay'ah (RDB 2 and UL), Jebel Mimiyah (MIM 1), Ruwais (RUW UL ), and Gerain al Aysh (GAA 1, 2, and 3). 
Kingston's (1999) tooth enamel data come from $\operatorname{HMR}(1,5$, and UL), JBR (2 and 'east'), JDH ( $3,4,5$, and UL), KIH (1 and UL), RDB 2, SHU (1 and 4), and THM 4. Some of Kingston's (1999) fossil enamel samples are not associated with a specimen number, but rather identified only by his 'AD' numbering system (not to be confused with cataloged specimen numbers, which begin with AUH). His pedogenic carbonate samples all come from Hamra (HMR 5), Kihal (KIH 1), and unknown localities at Shuwaihat (SHU UL) and Jebel Barakah (JBR UL). Kingston's 'site numbers' are also his own and not to be confused with actual fossil localities (e.g. his 'sites H12-16' are all from locality HMR 5).

Paleomagnetostratigraphic work indicates the entire Baynunah Formation was deposited in less than $750 \mathrm{kyr}$, and perhaps in as little as 300-200 kyr (Peppe et al. this volume). This, in combination with the fact that depositional environments are broadly similar across localities, leads us to consider the ages of all stable isotope samples from the Baynunah fossil localities as broadly contemporaneous.

\subsection{Methods}

\subsubsection{Stable isotopes in vegetation and teeth}

In tropical and subtropical ecosystems today, woody plants use the $\mathrm{C}_{3}$ photosynthetic pathway, or Calvin cycle, while low elevation $(<1500 \mathrm{~m})$ grasses, some sedges (e.g., Cyperus papyrus), and select shrubs (e.g., Salsola sp.) use the $\mathrm{C}_{4}$ pathway, or Hatch-Slack cycle (Cerling and Harris 1999; Livingstone and Clayton 1980; Tieszen et al. 1979; Young and Young 1983).

The carbon isotope ratio of $\mathrm{C}_{3}$ plants today is around $-28 \%$ on average with an observed range of about -36 to $-23 \%$. The wide range in $\delta^{13} \mathrm{C}$ values in the bulk tissues of $\mathrm{C}_{3}$ plants is controlled by environmental conditions: more negative values are found in closed canopy forests 
whereas xeric conditions - common across the Arabian Peninsula today-lead to more positive values (e.g., -26 to $-23 \%$ ). $\mathrm{C}_{4}$ plants exhibit a narrower range of values, from about -14 to -10 \%o (Cerling et al. 2003b). Stable carbon and oxygen isotope ratios are reported as delta $(\delta)$ values relative to the Pee Dee Belemnite (PDB) standard using permil (\%o) notation where

$$
\delta^{13} \mathrm{C}\left(\text { or } \delta^{18} \mathrm{O}\right)=\left(\mathrm{R}_{\text {sample }} / \mathrm{R}_{\text {standard }}-1\right) \times 1000
$$

and $\mathrm{R}_{\text {sample }}$ and $\mathrm{R}_{\text {standard }}$ are the ${ }^{13} \mathrm{C} /{ }^{12} \mathrm{C}\left({ }^{18} \mathrm{O} /{ }^{16} \mathrm{O}\right)$ ratios in the sample and in the standard, respectively, and the $\delta^{13} \mathrm{C}$ and $\delta^{18} \mathrm{O}$ values of PDB are defined as $0 \%$.

Terrestrial plants produce long chain $n$-alkyl lipids primarily as epicuticular waxes on their leaves (Eglinton and Hamilton 1967). The two types of $n$-alkyl lipids analyzed in this study are $n$-alkanes, which are linear, saturated hydrocarbon molecules, and $n$-alkanoic acids, which are similar in structure to $n$-alkanes but have a terminal carboxyl group. $n$-Alkanoic acids are commonly referred to as fatty acids. Due to their structure, $n$-alkanes and fatty acids are recalcitrant and resistant to microbial breakdown, and are therefore commonly preserved in fluvio-lacustrine sediments over millions of years (Uno et al. 2016b). While there are a variety of $n$-alkyl lipid sources in sediments, terrestrial plants produce long chain homologs, generally those with $>26$ carbon chainlengths. Whereas, short chain $n$-alkyl lipids $\left(\mathrm{C}_{8}\right.$ to $\left.\mathrm{C}_{18}\right)$ are produced by bacteria or microbes and mid-chain lipids $\left(\mathrm{C}_{19}\right.$ to $\left.\mathrm{C}_{25}\right)$ can also be microbial in origin or come from aquatic macrophytes or sphagnum (Corrigan et al. 1973; Cranwell et al. 1987; Ficken et al. 2000; Nott et al. 2000). In terrestrial plants, odd numbered $n$-alkanes homologs (e.g., $\mathrm{C}_{27}, \mathrm{C}_{29}$, and $\mathrm{C}_{31}$ ) occur in higher concentrations compared to even-numbered ones. The odd-over-even preference in $n$-alkanes provides a unique signature of plant origin. A common measure of this metric is the carbon preference index (CPI), which is calculated using the equation from Marzi et al. (1993) for both $n$-alkanes and fatty acids. The CPI of plants ranges widely, but is generally 
between 5 and 40 (Bush and McInerney 2013), and is usually lower, from about 2 to 10, in soils (Bush and McInerney 2015). Plant-derived fatty acids show a similar pattern, but instead have an even-over-odd preference. Petroleum also consists of $n$-alkanes, but has a CPI of $\sim 1$, which allows CPI to be used to verify that $n$-alkyl lipids are from plants rather than petroleum. We also report the average chain length (ACL), which is an abundance weighted average of the area of odd numbered $n$-alkanes homologs $\left(\mathrm{C}_{27}\right.$ to $\left.\mathrm{C}_{35}\right)$ or even numbered fatty acids $\left(\mathrm{C}_{26}\right.$ to $\left.\mathrm{C}_{34}\right)$.

In the early 1990s, Hayes and colleagues developed a method to measure carbon isotope ratios of $n$-alkyl lipids and other molecular biomarkers, paving the way for paleovegetation studies using compound specific isotope analysis of biomarkers (Freeman et al. 1990; Hayes et al. 1990). Carbon isotope measurements of $n$-alkanes from terrestrial sedimentary archives can be used to determine the proportion of $\mathrm{C}_{3}$ to $\mathrm{C}_{4}$ plants on the landscape, similar to carbon isotope ratios in soil organic matter (Baczynski et al. 2016; Freeman and Colarusso 2001; Uno et al. 2016b).

Stable carbon and oxygen isotope ratios of tooth enamel are determined by an animal's diet and body water, respectively, and therefore can be used to reconstruct herbivore diets, vegetation, and local hydroclimate in past ecosystems (Kingston and Harrison 2007; Levin et al. 2006; e.g., Uno et al. 2011). Carbon isotopes in enamel from large herbivores reflect the proportion of $\mathrm{C}_{3}$ to $\mathrm{C}_{4}$ vegetation in their diet during the time in which the tooth formed. Oxygen isotopes in enamel are primarily determined by the isotope ratio of precipitation but also influenced by food water; plant water; evaporative processes in soils, plants, and water sources; and animal physiology (Kohn et al. 1996; Levin et al. 2006; Luz et al. 1984). Stable carbon and oxygen isotope ratios of tooth enamel are reported as delta $(\delta)$ values relative to the Pee Dee Belemnite (PDB) standard using permil (\%o) notation given equation 1. 


\subsubsection{Carbon isotope enrichment in plant waxes and tooth enamel}

Carbon isotope fractionation occurs during the synthesis of plant waxes and during tooth enamel formation. Isotope fractionation is expressed using the term alpha $(\alpha)$, and it occurs during biological processes that include but are not limited to diffusion, enzymatic fixation of carbon, synthesis of lipids, and mineralization. The fractionation between two substrates is described by the following equation

$$
\alpha_{\text {atm-plant }}=\frac{1000+\delta^{13} C_{a t m}}{1000+\delta^{13} C_{\text {plant }}}
$$

where the fractionation between atmospheric and plant bulk tissue carbon $\left(\alpha_{\text {atm-plant }}\right)$ is a function of the $\delta^{13} \mathrm{C}$ values of the atmosphere and plant. Isotopic enrichment $(\varepsilon)$ is another term used to describe changes in the $\delta^{13} \mathrm{C}$ value between substrates and is related to $\alpha$ through the following equation:

$$
\varepsilon_{\text {atm-plant }}=\left(\alpha_{\text {atm-plant }}-1\right) \times 1000
$$

The enrichment factors are necessary for deriving endmember values of $\mathrm{C}_{3}$ and $\mathrm{C}_{4}$ for bulk plant tissue, biomarkers, and tooth enamel and are therefore reviewed here. Using known enrichment factors (Table 18.1), the $\mathrm{C}_{3}$ and $\mathrm{C}_{4}$ endmembers can be calculated as follows by rearranging equations 2 and 3 ,

$$
\delta^{13} C_{\text {plant }}=\frac{1000+\delta^{13} C_{a t m}}{\frac{\varepsilon_{\text {atm-plant }}}{1000}+1}-1000
$$

The carbon isotope enrichment associated with the synthesis of $n$-alkanes by the plant results in $\delta^{13} \mathrm{C}$ values more depleted than bulk plant tissue. In this study we use an enrichment factor, 
denoted as $\varepsilon *_{\text {lipid-plant }}$, of $-8 \%$. This is based on the $*_{\text {lipid-plant }}$ mean values determined for $\mathrm{C}_{3}$ and $\mathrm{C}_{4}$ plants from Collister et al. (1994). We apply the same $\varepsilon^{*}$ lipid-plant of $-8 \%$ for fatty acids but acknowledge this number is not yet as well constrained as the value for $n$-alkanes.

For tooth enamel, we use an isotopic enrichment between diet and enamel, denoted as $\varepsilon^{*}$ enamel-diet, of $14.1 \pm 0.5 \%$, as determined by Cerling and Harris (1999) for large ungulates. The $\varepsilon^{*}{ }_{\text {enamel-diet }}$ value in mammals has recently been found to vary with body mass and the degree of methanogenesis in the gut (Tejada-Lara et al. 2018), with medium to large ungulates generally between 13 and $15 \%$. Uncertainties in estimating precise body mass for the Baynunah fauna preclude application of the equations developed by Tejada-Lara and colleagues for determining $\varepsilon^{*}{ }_{\text {enamel-diet, }}$ so here we use a single value of $14.1 \%$.

\subsection{3. $C_{3}$ and $C_{4}$ endmembers from plant waxes and tooth enamel}

In addition to enrichment factors, the atmospheric $\delta^{13} \mathrm{C}$ value $\left(\delta^{13} \mathrm{C}_{\mathrm{atm}}\right)$ must be known or estimated in order to establish the $\mathrm{C}_{3}$ and $\mathrm{C}_{4}$ endmembers for carbon isotope ratios of plant waxes $\left(\delta^{13} C_{\text {alkane }}, \delta^{13} C_{\text {acid }}\right)$ and tooth enamel $\left(\delta^{13} C_{\text {enamel }}\right)$. We use the mean value of $-6.3 \%$ for the $\delta^{13} \mathrm{C}_{\text {atm }}$ based on the high resolution benthic foraminifera record from 6 to $8 \mathrm{Ma}$ from Tipple et al. (2010). We use this time interval because it best matches the estimated age for the Baynunah Formation (Bibi et al.this volume; Peppe et al. this volume). By combining the $\delta^{13} \mathrm{C}_{\text {atm }}$ and the biosynthetic fractionation factors for $C_{3}$ and $C_{4}$ plants, the $C_{3}$ and $C_{4}$ endmember $\delta^{13} C$ values of bulk tissue can be calculated (Table 18.1). By further applying the enrichment values $\varepsilon^{*}{ }_{\text {lipid-plant }}$ of $-8 \%$ and $\varepsilon^{*}$ enamel-diet of $14.1 \%$, the $\mathrm{C}_{3}$ and $\mathrm{C}_{4}$ endmembers for $\delta^{13} \mathrm{C}_{\text {alkane }}$ and $\delta^{13} \mathrm{C}_{\text {enamel }}$ can be determined. This results in endmember $\delta^{13} \mathrm{C}_{\text {alkane }}$ values of $-33.1 \%$ and $-18.8 \%$ for $\mathrm{C}_{3}$ and $\mathrm{C}_{4}$ 
vegetation, respectively. Endmember $\delta^{13} \mathrm{C}_{\text {enamel }}$ are $-11.4 \%$ and $+3.2 \%$ for pure $\mathrm{C}_{3}$ and $\mathrm{C}_{4}$ diets, respectively. The $\delta^{13} \mathrm{C}_{\text {atm }}$ value, enrichment factors, and calculated endmember values are presented in Table 18.1.

With endmember values established, two-member mixing models can be used to estimate the proportion of $\mathrm{C}_{4}$ vegetation on the landscape or in mammalian diets using $\delta^{13} \mathrm{C}_{\text {alkane }}$ and $\delta^{13} C_{\text {enamel }}$ values, respectively. For plant waxes, we convert only the $\delta^{13} C_{\text {alkane }}$ values percent $C_{4}$ $(\% \mathrm{C} 4)$ because the carbon isotope systematics of $n$-alkanes are better constrained than for acids using the following equation,

$$
\% C 4=\frac{\left(\delta^{13} C_{C 3}-\delta^{13} C_{\text {alkane }}\right)}{\left(\delta^{13} C_{C 3}-\delta^{13} C_{C 4}\right)} \times 100
$$

where $\delta^{13} \mathrm{C}_{\text {alkane }}$ is the measured $\delta^{13} \mathrm{C}$ value of the sample and $\delta^{13} \mathrm{C}_{\mathrm{C} 3}$ and $\delta^{13} \mathrm{C}_{\mathrm{C} 4}$ are the calculated $\mathrm{C}_{3}$ and $\mathrm{C}_{4}$ endmember values for $n$-alkanes. We propagate the uncertainty in both the $n$-alkane endmember values and in the analytical procedure $( \pm 0.1 \%)$, which results in uncertainties of ca. 12 to $23 \%$. We note that uncertainties in the calculated $\% \mathrm{C}_{4}$ are higher towards the $\mathrm{C}_{3}$ end of the continuum due to the larger uncertainty of the $\mathrm{C}_{3}$-endmember value, which is $\pm 4 \%$. We use the same equation (2) to estimate the $\% \mathrm{C} 4$ in the diet of Baynunah mammals by substituting in the $\delta^{13} \mathrm{C}_{\text {enamel }}$ for $\delta^{13} \mathrm{C}_{\text {alkane }}$ and the enamel $\mathrm{C}_{3}$ and $\mathrm{C}_{4}$ endmembers (Table 18.1). Using the average $\mathrm{C}_{3}$ and $\mathrm{C}_{4} \delta^{13} \mathrm{C}_{\text {enamel }}$ values we define $\mathrm{C}_{3}$-dominated diets as those with $\delta^{13} \mathrm{C}_{\text {enamel }}$ values of $<-7.8$ $\% 0\left(<25 \% \mathrm{C}_{4}\right)$, mixed $\mathrm{C}_{3}-\mathrm{C}_{4}$ diets as having values from -7.8 to $-0.5 \% 0\left(25-75 \% \mathrm{C}_{4}\right)$, and $\mathrm{C}_{4^{-}}$ dominated diets as those with $\delta^{13} \mathrm{C}_{\text {enamel }}$ values of $>-0.5 \%\left(>75 \% \mathrm{C}_{4}\right)$. Finally, we also incorporate into pedogenic carbonate carbon isotope data published by Kingston (1999) into 
vegetation reconstructions. The $\% \mathrm{C}_{4}$ is similarly calculated from the $\delta^{13} \mathrm{C}$ value of the pedogenic carbonate $\left(\delta^{13} C_{p c}\right)$ using equation 2 and the endmember values given in Table 18.1.

\subsubsection{Plant wax sampling and analysis}

Approximately $500 \mathrm{~g}$ of sediment was collected for plant wax analyses. The sampling protocol was designed to prevent contamination from modern plant biomarkers in the field. Samples were collected by trenching 10 to $80 \mathrm{~cm}$ into outcrop surfaces to expose fresh, unweathered sediment. Samples were collected in places where there was little to no overlying modern vegetation and all samples were screened for modern roots, which can be a source of modern $n$ alkyl lipids, particularly fatty acids (Mueller et al. 2012). Sediment was collected onto aluminum foil and the sample collector (K. Uno) wore nitrile gloves to prevent any oils or other foreign lipid sources from contaminating the samples.

In the lab, samples were rinsed with dichloromethane (DCM), an organic solvent, to remove any possible contaminants. A subset of each sample was then crushed to a powder in a mortar and pestle. Lipids were extracted from 103 to $131 \mathrm{~g}$ (median: $119 \mathrm{~g}$ ) of powdered sediment with organic solvents (9:1 DCM : methanol) using a Dionex Accelerated Solvent Extractor in batches of approximately $60 \mathrm{~g}$ of sample packed into $66 \mathrm{ml}$ extraction cells. Samples were extracted with four $10 \mathrm{~min}$ static cycles at $100^{\circ} \mathrm{C}$ with a solvent flush volume of $150 \%$ of total cell volume. An internal standard was added to the total lipid extract (TLE) that included $5 \alpha$-androstane and cis-11-eicosenoic acid (2,000 $\mathrm{ng}$ of each) for later quantification of lipids.

The TLE was separated by solid phase extraction on silica gel columns (approx. $0.5 \mathrm{~g}$ solvent rinsed silica gel, 230-400 mesh). The aliphatic fraction (F1), which contained $n$-alkanes, was eluted with $4 \mathrm{ml}$ of hexane, the ketone and ester fraction (F2) eluted with $4 \mathrm{ml}$ of DCM, and 
the polar fraction (F3) with $4 \mathrm{ml}$ of methanol. The F3 fraction was then separated through an aminopropyl column (approx. $0.5 \mathrm{~g}$ ) where the neutral, acid (A) and polar fractions were eluted with $4 \mathrm{ml}$ each of 2:1 DCM:iso-propanol, $4 \%$ acetic acid in diethyl ether, and methanol, respectively. Carboxylic acids in the F3A fraction were methylated (Me) with acidic methanol at $60^{\circ} \mathrm{C}$ for $4-12 \mathrm{~h}$, yielding fatty acid methyl esters. Fatty acid methyl esters in the F3AMe fraction were isolated from molecules such as hydroxy acids containing additional functional groups using silica gel columns (as above), where the F2 fraction contained the fatty acids for analysis.

$n$-Alkane and fatty acids were quantified and characterized on an Agilent gas chromatograph (Agilent 7890A GC) with DB-5 column (30 m length, $250 \mathrm{~mm} \mathrm{ID)}$ and a mass selective detector (5975C MSD) and flame ionization detector (FID). One microliter of sample dissolved in $100 \mu \mathrm{l}$ hexane was injected into a multi-mode inlet injector at $60^{\circ} \mathrm{C}(0.1 \mathrm{~min}$ hold $)$, which was then ramped to $320^{\circ} \mathrm{C}$ at $900^{\circ} \mathrm{C}$ per minute and held for the duration of the analysis.

The initial $\mathrm{GC}$ oven temperature was set at $60^{\circ} \mathrm{C}$ and ramped to $150^{\circ} \mathrm{C}$ at $15^{\circ} \mathrm{C}$ per minute, then ramped to $320^{\circ} \mathrm{C}$ at $4^{\circ} \mathrm{C}$ per minute and held there for the duration of the analysis. The sample, carried by a He stream was quantitatively split to the MSD and FID detectors through a microfluidics device downstream of the column. Compound identification was done with comparison of mass spectra and retention times to authentic standards, and quantification was done by integrating peak areas of the mass 57 ion for $n$-alkanes and the mass 74 ion for fatty acids. $n$-Alkyl lipid concentrations were calculated based upon the peak area of known concentrations of internal standards added to the TLE. We used a response factor correction to account for ionization biases between the $5 \alpha$-androstane standard (a synthetic steroid) and the $n$ alkanes for more accurate quantification of concentrations. 
Carbon isotope ratios of $n$-alkanes and fatty acids were analyzed using a Thermo Trace GC coupled to a Thermo Delta V isotope ratio mass spectrometer through an Isolink combustion interface at the Lamont Doherty Earth Observatory (LDEO) Stable Isotope Laboratory. All sample injections were interspersed with injections of molecular mixtures with known isotopic values (mixes A4, A5 and F8 supplied by Arndt Schimmelmann, Univ. of Indiana) that were used for correction of carbon isotope values. Fatty acid $\delta^{13} \mathrm{C}$ values were corrected for the addition of the methyl group using a mass balance equation and the measured $\delta^{13} \mathrm{C}$ value of the methanol used for methylation. All $\delta^{13} \mathrm{C}$ values were corrected for analytical uncertainty, including the ref gas uncertainty, using a Matlab script as described in Polissar and D'Andrea (2014).

\subsubsection{Enamel sampling, pretreatment, and isotope analysis}

Sampling of fossil teeth for stable isotopes was performed by KU in Abu Dhabi and at the University of Utah. Fossil teeth were selected from nine mammalian families. Prior to drilling, each tooth was inspected, photographed, and a sampling location on the tooth was evaluated.

The sample protocol for bulk sampling involved sampling along broken enamel surfaces whenever possible, or in some cases a lateral tooth surface, using a Dremel handheld drill with carbide (Brasseler) or diamond grit impregnated (Lasco) bits at low speed ( 2000 RPM). No occlusal surfaces were drilled. The sample surface was prepared by abrading the enamel surface with the drill bit. On lateral surfaces, this removed surface adherents and the outermost enamel (ca. $100 \mu \mathrm{m})$. If present, cementum was drilled away to expose enamel. After visual inspection of the prepared surface with a hand lens, a narrow groove about $1 \mathrm{~mm}$ deep and 1 to $2 \mathrm{~mm}$ wide was drilled parallel to the growth axis of the tooth. Sample groove lengths varied based on tooth 
geometry imposed additional constraints (enamel thickness and crown length), but ideally were 10 to $15 \mathrm{~mm}$ long to average out potential seasonal variability in diet and water. Sample masses ranged from about 3 to $15 \mathrm{mg}$.

Six equid molars were serially sampled along the growth axis of the tooth to generate intratooth isotope profiles. Cementum was cleared away using the Dremel to expose a window of the fossil enamel. The exposed area was $\sim 5 \mathrm{~mm}$ wide and ran the length of the tooth crown (30 to $60 \mathrm{~mm}$ ). Samples were drilled every $3 \mathrm{~mm}$ along the growth axis of the tooth, with sample grooves oriented normal to the growth axis. Sample grooves were $<1 \mathrm{~mm}$ deep, $\sim 1 \mathrm{~mm}$ wide, and 3 to $6 \mathrm{~mm}$ long. Sample masses were about $2-5 \mathrm{mg}$.

Enamel powders from bulk and intratooth profile samples were pretreated prior to stable isotope analysis with $3 \% \mathrm{NaOCl}$ (bleach) for 30 minutes in $1.7 \mathrm{ml}$ centrifuge tubes that were stirred every 10 minutes on a vortex mixer. After the reaction period, samples were centrifuged and the supernatant was removed. Each sample was then rinsed three times with distilled water. The rinse procedure involved adding de-ionized (DI) water, stirring on the vortex mixer, then centrifuging the sample and removing the supernatant. Next, samples were treated with $0.1 \mathrm{M}$ Na-acetate buffered acetic acid for 30 minutes, as above, and following three distilled water rinses were loosely covered and dried overnight in a fume hood. Approximately 300 to $600 \mu \mathrm{g}$ of powdered enamel sample was weighed out into silver capsules, along with NBS-19 standard (20-50 $\mu \mathrm{g})$ and internal enamel standards. Samples and standards were roasted in vacuo for 2 hours at $60^{\circ} \mathrm{C}$ to remove adsorbed water.

Serial samples were analyzed at the University of Utah using a Finnigan Carboflo device coupled to a MAT 252 isotope ratio mass spectrometer (IRMS). Enamel samples were reacted with phosphoric acid at $90^{\circ} \mathrm{C}$ for 10 minutes under a He stream and exsolved $\mathrm{CO}_{2}$, produced 
from the $\mathrm{H}_{3} \mathrm{PO}_{4}$ reaction, was cryogenically focused in a liquid nitrogen trap. The $\mathrm{CO}_{2}$ was cryogenically transferred to a microvolume at $-170^{\circ} \mathrm{C}$ and then inlet into the IRMS via dual inlet mode at $-60^{\circ} \mathrm{C}$.

Bulk enamel samples were analyzed at the LDEO Stable Isotope Laboratory using a Kiel IV device coupled to an IRMS. The Kiel differs from the CarboFlo in that it uses single reaction vessels rather than a common acid bath. As such, bulk enamel samples were transferred from silver capsules to round bottom, glass reaction vials after roasting in vacuo. A strand of silver wool was added to each vial to oxidize any $\mathrm{SO}_{2}$ produced in the reaction. Sample vials were loaded into the Kiel, where they were reacted with phosphoric acid at $70^{\circ} \mathrm{C}$ for 10 minutes in vacuo. Exsolved gases were cryogenically transferred to a microvolume held at $-170^{\circ} \mathrm{C}$, and then transferred to second microvolume with the first held at $-70{ }^{\circ} \mathrm{C}$ to remove water. The purified sample $\mathrm{CO}_{2}$ was inlet to a dual-inlet Delta V Plus IRMS.

All carbon and oxygen isotope ratios were corrected using international and internal standards. The standard deviation of NBS-19 throughout sample runs was $\sim 0.05 \%$ for $\delta^{13} \mathrm{C}$ and $<0.10 \%$ for $\delta^{18} \mathrm{O}$. Oxygen isotope values were converted from $\mathrm{CO}_{2}$ (gas) to fossil enamel (mineral) values using temperature dependent fractionation factors $\left(1.00799\right.$ for $70^{\circ} \mathrm{C} ; 1.00725$ for $90^{\circ} \mathrm{C}$ ) using the equation for fossil enamel (Eq. 4) in Passey et al. (2007).

We combine bulk tooth enamel carbon and oxygen isotope data analyzed for this study ( $n=35)$ with those previously published ( $n=30)$ by Kingston (1999). In order to compare the $\delta^{18} \mathrm{O}$ values from Kingston (1999) to those determined in this study, we recalculated values from the previous study, originally calculated using the calcite-based acid fractionation factor, using a tooth enamel specific, temperature dependent acid fractionation factor (Eq. 3) from Passey et al. (2007). This is necessary so that the $\delta^{18} \mathrm{O}$ values from both data sets can be directly compared. 
To do this, we converted the $\delta^{18} \mathrm{O}$ values from mineral back to $\mathrm{CO}_{2}$ (gas) $\delta^{18} \mathrm{O}$ values using the commonly applied calcium carbonate acid fractionation factor of 1.00819 (Swart et al. 1991). We then apply the tooth enamel acid fractionation factor from Passey et al. (2007) for a sealed vessel reaction at $90^{\circ} \mathrm{C}$, where $\alpha=1.00725$, so that the Kingston (1999) data are placed in the same reference framework as our data. The difference between the originally published and recalculated $\delta^{18} \mathrm{O}$ values for the modern enamel samples is on the order of $+0.99 \%$.

\subsubsection{Intratooth stable isotope profiles and inverse modeling}

Intratooth isotope profiles of herbivore tooth enamel provide a time series of the diet and body water over the period in which the tooth enamel formed (Fricke and O'Neil 1996; Sharp et al. 1998). For obligate drinkers such as equids, the $\delta^{18} \mathrm{O}_{\text {enamel }}$ values track meteoric water (Huertas et al. 1995). This is supported by feeding and drinking observations, which show that in warm environments with air temperatures similar to Abu Dhabi today $\left(30\right.$ to $\left.35^{\circ} \mathrm{C}\right)$, mares drink every $\sim 2$ hrs during the heat of the day (Crowell-Davis et al. 1985). Thus, the first order control on $\delta^{18} \mathrm{O}_{\text {enamel }}$ is meteoric water. In extant equids, premolars and molars form over 1.5 to 2.8 years, inclusive of crown extension and enamel maturation (Hoppe et al. 2004). The time represented in intratooth isotope profiles can therefore be used to evaluate seasonal variability in precipitation, vegetation, and diet (Metcalfe et al. 2011; Nelson 2005; Sharp et al. 1998).

Amelogenesis, or the process of enamel formation, is a two-stage process that starts with a secretory stage, when enamel matrix is deposited, followed by a protracted maturation stage, when density of the original matrix increases significantly (Suga 1979). As a result, the isotope ratio of a given volume of enamel represents a time integrated signal of the initial period of matrix deposition and the period of maturation. Tooth enamel maturation and isotope sampling methods blur and attenuate the original isotope input signal (Passey \& Cerling 2002; Zazzo et al 
2005). To unblur the signal, we apply the inverse method developed by Passey et al. (2005) to estimate the original input signals for $\delta^{13} \mathrm{C}_{\text {enamel }}$ (diet) and $\delta^{18} \mathrm{O}_{\text {enamel }}$ (body water) that more closely reflect the actual diet and body water composition of the equid during the time during in which the tooth formed. The inverse model requires input parameters that related to tooth formation, isotope sampling geometry, and isotope analysis. Input parameters relevant to tooth enamel formation, or amelogenesis, include initial enamel density $\left(f_{i}\right)$, enamel appositional length $\left(l_{a}\right)$ and maturation length $\left(1_{\mathrm{m}}\right)$ (Passey and Cerling 2002). We use parameters measured on Equus ferus przewalskii by (Blumenthal et al. 2014) as estimates for equid molars used here, where $\mathrm{f}_{\mathrm{i}}=$ $22 \%, 1_{\mathrm{a}}=6 \mathrm{~mm}, 1_{\mathrm{m}}=28 \mathrm{~mm}$. Sample input variables include distance between samples $(3 \pm 0.5$ $\mathrm{mm})$ and depth $(0.7 \mathrm{~mm} \pm 0.2 \mathrm{~mm})$. The final input variables are the measured carbon and oxygen isotope data and their associated uncertainties, which were smoothed with a 3-point weighted mean (0.25:0.5:0.25). A measured error term, $\mathrm{E}_{\text {meas }}$, is computed from measurement uncertainties in isotope values and sample measurements. This term ultimately governs model sensitivity that is then used to determine an appropriate damping factor $(\varepsilon)$. The model requires selection of a damping factor that minimizes the difference between $\mathrm{E}_{\text {meas }}$ and the prediction error $\left(\mathrm{E}_{\mathrm{pred}}\right)$. A detailed description of additional model parameters and the regularization method is given in Passey et al. (2005). Model code was downloaded and adapted from Passey et al. (2005). While it is widely accepted that ungulate cheek teeth have non-linear growth rates, particularly towards the base of the of crown (Bendrey et al. 2015; Zazzo et al. 2012), the inverse model requires us to assume a constant growth rate. The difference between linear vs. exponential growth rates has the greatest effect in the lowermost portion of the crown. Across the main part of the crown, a linear approximation of growth rate is reasonable (see fig. 4 in Bendrey et al. 2015). We sampled teeth in this study that were not heavily worn so most samples come 
from regions of the teeth where growth rates can be approximated as linear. Further work on the mode and rates of growth in ungulate cheek teeth may help produce even more precise models in the future.

\subsubsection{Climate and precipitation records}

Meteorological and soil data collected from 1971-1999 at the Abu Dhabi weather station (WMO Station \#41216 at the Bateen Airport; $24.43^{\circ} \mathrm{N}, 54.45^{\circ} \mathrm{E}$ ) are used to establish a modern baseline for monthly precipitation, mean annual precipitation (MAP), monthly temperature, mean annual temperature (MAT), and maximum monthly mean soil temperature from the NOAA database (NOAA 2018) (Fig. 18.2). The average $\delta^{18} \mathrm{O}$ value of precipitation for Abu Dhabi is calculated using the average of three values from the area. The first estimated value is from published $\delta^{18} \mathrm{O}$ data for the closest GNIP station (WMO Station \# 4115001 at the Bahrain Airport, $26.27^{\circ} \mathrm{N}, 50.62^{\circ} \mathrm{E}$ ) located $\sim 320 \mathrm{~km}$ northwest of the Baynunah fossil sites (IAEA/WMO 2019). The second is from a published $\delta^{18} \mathrm{O}$ value for United Arab Emirates (UAE) precipitation (Rizk and Alhsharhan 2003). The third is an estimate for the fossil site region using the Online Isotopes in Precipitation Calculator (OIPC, Bowen 2018; Bowen and Revenaugh 2003).

Fig. 18.2 near here. Width $=1$ column

Modern climate data are compared to water isotope data reconstructed from oxygen isotopes in pedogenic carbonate (Kingston 1999) and tooth enamel (Kingston 1999; this study). Mineral phase (carbonate and apatite) oxygen isotope ratios (PDB) are converted to water 
oxygen isotope ratios (VSMOW) using the equation for determining the isotope fractionation by Kim and O’Neil (1997).

In the case of pedogenic carbonates, we calculate soil water oxygen isotope values $\left(\delta^{18} \mathrm{O}_{\text {sw }}\right)$ using the reported maximum monthly mean modern soil temperature of $35^{\circ} \mathrm{C}$ at $50 \mathrm{~cm}$ depth in Abu Dhabi as an estimate for late Miocene soil temperatures (NOAA 2018). For tooth enamel, we calculate body water oxygen isotope values $\left(\delta^{18} \mathrm{O}_{\mathrm{bw}}\right)$ of Baynunah hippos. Due to their semi-aquatic habitat, hippo $\delta^{18} \mathrm{O}_{\mathrm{bw}}$ values best reflect meteoric water (Bocherens et al. 1996; Cerling et al. 2008; Levin et al. 2006). We apply the same Kim and O’Neil (1997) equation using a standard mammalian body temperature of $37^{\circ} \mathrm{C}$. This yields an enrichment factor $\left(\varepsilon_{\mathrm{bw}-\mathrm{en}}\right)$ between body water $\delta^{18} \mathrm{O}\left(\delta^{18} \mathrm{O}_{\mathrm{bw}}\right)$ and enamel $\delta^{18} \mathrm{O}\left(\delta^{18} \mathrm{O}_{\mathrm{en}}\right)$ of $26.0 \%$, which is nearly identical to the experimentally derived value of $26.3 \pm 0.14 \%$ determined by Bryant et al. (1996). Taken together, reconstructed soil water and hippo body water $\delta^{18} \mathrm{O}$ values can be compared to the modern measured (GNIP database, IAEA/WMO 2019, and Rizk and Alhsharhan 2003) and OIPC modelled $\delta^{18} \mathrm{O}$ of precipitation values.

\section{Results}

\subsection{Plant waxes}

\subsubsection{Plant wax concentrations}

Plant wax concentration, CPI, and ACL for seven samples from four sites - HMR 5, KIH 2, MLS 1, and RUW SE - are given in Table 18.2. Plant wax concentrations range from 1.8 to 64.6 $\mathrm{ng} / \mathrm{g}$ sediment for the $n-\mathrm{C}_{31}$ alkane and 0.4 to $66.0 \mathrm{ng} / \mathrm{g}$ sediment for the $n-\mathrm{C}_{30}$ fatty acid, both of which are generally the most commonly reported homologs for their compound classes. For the $n$-alkanes, most samples exhibit a $\mathrm{C}_{31}$ maximum with high abundances of $\mathrm{C}_{29}$ and $\mathrm{C}_{27}$ homologs 
and low abundances of the longer chain homologs, $\mathrm{C}_{33}$ and $\mathrm{C}_{35}$. Fatty acid samples have compound maxima ranging mostly from $\mathrm{C}_{24}$ to $\mathrm{C}_{28}$. Relative abundances of $n$-alkane and fatty acid chain-lengths are illustrated in Fig 18.3. n-Alkane CPIs range from 3.1 to 6.7 and fatty acid CPIs range from 2.2 to 2.6. These CPI values all indicate preservation of the primary plant wax signal. n-Alkane ACLs range from 28.8 to 30.5, whereas fatty acid ACLs are slightly shorter, ranging from 27.0 to 28.0 .

Fig. 18.3 here. Width $=$ Full page width

Table 18.2 near here. Width $=$ full page

Overall, the concentrations, CPI, and ACL all indicate preservation of the primary plant wax signal for the longer chains $\left(>\mathrm{C}_{30}\right)$, and we note some samples have lower CPIs across the midchain regions, potentially from algal, aquatic macrophytes, or post depositional processes. This is evident in fatty acid samples from KIH 2, MLS 1, and some from HMR 5. These midchain homologs are also present, although to a lesser degree, in the $n$-alkane samples (Fig. 18.3). They do not have a significant effect on the longer chain carbon isotope ratios or the vegetation reconstructions.

\subsubsection{Plant wax stable isotope ratios}

Carbon isotope ratios range from -29.2 to $-22.0 \%$ for long chain $n$-alkanes $\left(C_{27}\right.$ to $C_{35}$, Fig. 18.4). The $\mathrm{C}_{31}$ alkane ranges from -29.2 to $-22.6 \%$, which results in an estimated 27 to $73 \%$ $\mathrm{C}_{4}\left(\right.$ median $\left.=43 \% \mathrm{C}_{4}\right)$ vegetation on the landscape (Table 18.3). The $\mathrm{C}_{35}$ alkane, a sensitive indicator of $\mathrm{C}_{4}$ vegetation, ranges from -26.4 to $-23.1 \%$. Fatty acids $\delta^{13} \mathrm{C}$ values from all homologs range from -30.6 to $-21.5 \%$, similar but slightly larger than the range observed in the 
$n$-alkanes (Fig. 18.4). The $\mathrm{C}_{30}$ fatty acid ranges from -28.9 to $-22.9 \%$, nearly identical to the range observed in the $\mathrm{C}_{31}$ alkane. The biomarker sample from site MLS 1, a locality known for its preservation of a remarkable proboscidean trackway (Bibi et al. 2012), was the most open landscape with an estimated $73 \% \mathrm{C}_{4}$ vegetation. Samples from $\mathrm{HMR}$ and $\mathrm{KIH} 2$ yield similar

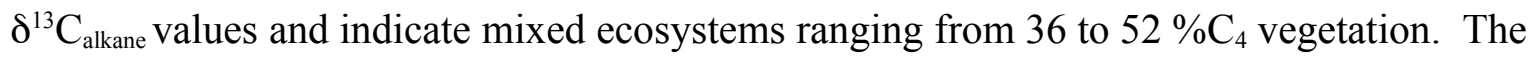
sample from RUW SE had the lowest amount of $\mathrm{C}_{4}$ vegetation $(27 \%)$.

Fig. 18.4 near here. Width $=$ full page.

Table 18.3 near here. Width $=$ full page

\subsection{Stable Isotopes in Teeth}

\subsubsection{Pretreatment results}

Eleven samples were analyzed with and without pretreatment (Figure 18.5). There is no difference in mean carbon values between treated and untreated samples $(0.0 \%)$, low variability $(1 \sigma=0.3 \%$ ), and a small absolute difference of $0.6 \%$ (Table 18.4). For oxygen, the mean difference is similarly small $(0.1 \%)$, but variability $(1 \sigma=1.2 \%$ ) and the absolute difference, $2.3 \%$, is high (Table 18.4). The slope of treated vs. untreated for both isotopes is close to 1 (Fig. 18.5).

Fig. 18.5 near here. Width $=$ full page

Table 18.4 near here. Width $=$ full page 


\subsubsection{Bulk samples}

Carbon and oxygen isotope values from fossil enamel yielded a wide range of values. Here we include analyses of fossil tooth enamel from Kingston (1999) for a total of 65 fossil teeth analyzed from Baynunah (Figure 18.6; Table 18.5). We include in Table 18.5 the original $\delta^{18} \mathrm{O}$ values provided in Kingston (1999, Table 1), but plot them all in the same reference framework as described in section 2.2.5. For carbon, the $\delta^{13} \mathrm{C}_{\text {enamel }}$ values ranged from $-13.2 \%$ to $+0.9 \%$, with a median value of $-2.2 \%$. Oxygen isotope values ranged $-9.5 \%$ to $+7.0 \%$, with a median value of $-4.5 \%$ (Table 18.5 ). Plotting tooth enamel stable isotope data by family illustrates the wide range of carbon and oxygen values at Baynunah (Fig. 18.7). The carbon isotope ratios were converted to percent $\mathrm{C}_{4}$ in diet using equation 2 , resulting in diets ranging from 0 to $84 \% \mathrm{C}_{4}$, with a median value of $63 \% \mathrm{C}_{4}$. Propagated uncertainty in $\% \mathrm{C}_{4}$ is reported in Table 18.5 and ranges from 12 to $23 \%$ (median $12 \%$ ), which should be noted in the ensuing discussions of diet. Only $15 \%$ of the sampled individuals had $\mathrm{C}_{3}$-dominated diets, about twothirds (65\%) had mixed $\mathrm{C}_{3}-\mathrm{C}_{4}$ diets, and the remaining $20 \%$ had $\mathrm{C}_{4}$-dominated diets. Most individuals ( $62 \%$ ) had diets consisting of $>50 \% \mathrm{C}_{4}$, confirming that $\mathrm{C}_{4}$ was the primary dietary source for Baynunah herbivores.

Fig. 18.6 near here. Width $=1$ column

Fig. 18.7 near here. Width $=$ full page

Table. 18.5 near here.

\subsubsection{Artiodactyls}

Box plots for carbon and oxygen are shown for bovids, giraffids, hippopotamids, and suids in Fig. 18.7. Bovid $\delta^{13} \mathrm{C}_{\text {enamel }}$ ranges from -10.4 to $+0.1 \%$, and $\delta^{18} \mathrm{O}_{\text {enamel }}$ from -5.0 to $-1.0 \%$ 
$(\mathrm{n}=5)$. The corresponding amount of $\mathrm{C}_{4}$ vegetation in diet is 7 to $79 \%$ (median $36 \%$, Table 18.5). Taxa include two Pachyportax latidens (51 and $\left.79 \% \mathrm{C}_{4}\right)$, two Tragoportax cyrenaicus $(7$ and $36 \% \mathrm{C}_{4}$ ), and one indeterminate bovid. Giraffid isotope values have an impressively wide range, with $\delta^{13} \mathrm{C}_{\text {enamel }}$ values ranging from -9.2 to $+0.2 \%$, with corresponding diets of 15 to 79 $\% \mathrm{C}_{4}($ median $=64 \% ; \mathrm{n}=6)$. Girrafid $\delta^{18} \mathrm{O}_{\text {enamel }}$ values range from -3.9 to $+7.0 \%$, and include the highest values recorded from Baynunah. Hippopotamids, represented by Archaeopotamus qeshta, yield $\delta^{13} \mathrm{C}_{\text {enamel }}$ values ranging from -5.5 to $+0.3 \%$ and $\delta^{18} \mathrm{O}_{\text {enamel }}$ values ranging from -9.5 to $-4.9 \%$ o $(n=11)$. Hippopotamid diets range from 40 to $80 \% \mathrm{C}_{4}($ median $=73 \%)$. Two Nyanzachoerus syrticus and one Propotamochoerus hysudricus specimens give a narrow range of $\delta^{13} \mathrm{C}_{\text {enamel }}$ values. Suids are mainly at the $\mathrm{C}_{3}$ end of the range, from -11.1 to $-9.7 \%$, which translates to 2 to $11 \% \mathrm{C}_{4}(\mathrm{n}=3)$. Suid $\delta^{18} \mathrm{O}_{\text {enamel }}$ values range from -5.0 to $-2.3 \%$. It is not known if the two suids from the Baynunah Formation were herbivores or omnivores, but presumably even omnivorous suids would have diets dominated by plant matter, and their enamel carbon isotope values must therefore reflect the vegetational composition of the diet.

\subsubsection{Perissodactyls}

Perissodactyls are represented by Equidae and Rhinocerotidae. The former are very common and the latter extremely rare in the Baynunah Formation. Equids are assigned to "Hipparion" abudhabiense and a smaller sized "Hipparion" (Bernor et al. this volume). Equid values range from -7.8 to $+0.9 \%$ for $\delta^{13} \mathrm{C}_{\text {enamel }}$ and from -7.3 to $+0.5 \%$ for $\delta^{18} \mathrm{O}_{\text {enamel }}(\mathrm{n}=24)$; (Fig 18.7). Diets of equids range from 24 to $84 \% \mathrm{C}_{4}$ (median $=63 \%$ ). The two rhinocerotid specimens were enamel fragments attributable only to the family level and have nearly identical $\delta^{13} \mathrm{C}_{\text {enamel }}$ 
values $(-10.4$ and $-10.2 \%)$ and $\delta^{18} \mathrm{O}_{\text {enamel }}$ values $(-5.5$ and $-5.3 \%$ ), with corresponding diets of 7 to $9 \% \mathrm{C}_{4}$.

\subsubsection{Proboscideans}

Fossils representing three proboscideans lineages, the Elephantidae, Deinotheriidae, and Gomphotheriidae, have been recovered from the Baynunah Formation (Sanders this volume). The most common by far is the newly erected elephantid species, Stegotetrabelodon emiratus, which has $\delta^{13} \mathrm{C}_{\text {enamel }}$ values of -7.3 to $-0.2 \%$ and $\delta^{18} \mathrm{O}_{\text {enamel }}$ values of -5.5 to $+0.5 \%$ (Fig 18.7). Stegotetrabelodon emiratus diets range from 28 to $77 \% \mathrm{C}_{4}($ median $=65 \%)$. The two deinotheriid (aff. Deinotherium bozasi) teeth sampled yield the most negative values from the Baynunah Formation measured to date, -13.2 and $-12.4 \%$, corresponding to pure $\mathrm{C}_{3}$ diets. The $\delta^{18} \mathrm{O}_{\text {enamel }}$ values are -4.6 and $-1.7 \%$. A single and somewhat enigmatic gomphotheriid tooth originally assigned to Stegotetrabelodon grandincisivus and now more conservatively assigned to Gomphotheriidae gen et sp. indet by Sanders (this volume), has a $\delta^{13} C_{\text {enamel }}$ value of $-4.3 \%$ o $\left(48 \% \mathrm{C}_{4}\right)$ and a $\delta^{18} \mathrm{O}_{\text {enamel }}$ value of $-2.6 \%$, which both fall within the range of values observed for S. emiratus (Fig. 18.7).

\subsubsection{Serially sampled equids}

The measured $\delta^{13} \mathrm{C}_{\text {enamel }}$ and $\delta^{18} \mathrm{O}_{\text {enamel }}$ values of six serially sampled equid teeth range from -7.1 to $+0.7 \%$ and from -6.8 to $+1.1 \%$, respectively $(n=84$, Table 18.6). The modeled ranges for both are larger, as expected because the model 'unblurs' the tooth enamel signal by accounting for sampling geometry and amelogenesis (Fig 18.8). Modeled $\delta^{13} \mathrm{C}_{\text {enamel }}$ and $\delta^{18} \mathrm{O}_{\text {enamel }}$ ranges from all profile samples are -8.2 to $+2.7 \%$ and -7.1 to $+4.4 \%$, respectively. For the modeled 
carbon data, this is equivalent to diets ranging from 22 to $97 \% \mathrm{C}_{4}$ vegetation (median $=56 \%$ ).

Within a single profile, the maximum modeled $\delta^{13} \mathrm{C}_{\text {enamel }}$ range is from -8.2 to $-1.9 \%$ (AUH

1566), equivalent to a 22 to $65 \% \mathrm{C}_{4}$ range in diet. The average modeled $\delta^{13} \mathrm{C}_{\text {enamel }}$ range is $5.3 \pm$

$0.8 \%$ o $(1 \sigma)$ (Fig 18.8). The highest range in the modeled $\delta^{18} \mathrm{O}_{\text {enamel }}$ data is from -6.2 to $+4.4 \%$ o

(AUH 1295) and the average range within a profile is $8.1 \pm 2.2 \%$.

Fig. 18.8 near here. Width = fit to page

Table. 18.6 near here.

Overall, the intratooth profiles exhibit quasi-periodic patterns of variability in both carbon and oxygen isotopes (Fig 18.8). The general trend is that $\delta^{13} \mathrm{C}_{\text {enamel }}$ values covary inversely with $\delta^{18} \mathrm{O}_{\text {enamel }}$ values, whereby more positive $\delta^{13} \mathrm{C}_{\text {enamel }}$ values occur with more negative $\delta^{18} \mathrm{O}_{\text {enamel }}$ values. Assuming the quasi-periodic cycles in the intratooth isotope profiles represent annual seasonality of vegetation and hydroclimate, then overall growth vertical rates of the equid cheek teeth can be estimated as 2.5 to $4 \mathrm{~cm} / \mathrm{yr}$, similar to the estimated growth rate in modern horses of 3 to $4 \mathrm{~cm} / \mathrm{yr}$ (Hoppe et al. 2004).

\subsubsection{Baynunah Hydroclimate}

Meteorological and soil data from the Abu Dhabi weather station (WMO Station \#41216; $24^{\circ}$ $26^{\prime} \mathrm{N}, 54^{\circ} 28^{\prime} \mathrm{E}$ ) record a mean annual precipitation (MAP) of $57 \mathrm{~mm}$ and a mean annual temperature (MAT) of $27^{\circ} \mathrm{C}$. Reported modern soil temperature of $35^{\circ} \mathrm{C}$ is in excess of mean annual air temperatures, which is commonly observed in arid ecosystems (Passey et al. 2010; Quade et al. 2013). The estimated $\delta^{18} \mathrm{O}$ values for annual precipitation $\left(\delta^{18} \mathrm{O}_{\text {precip }}\right)$ are given in 
Table 18.7 and have a mean value of $+0.5 \%$ (VSMOW), which is reasonable for a hyperarid region with very low rainfall.

Table. 18.7 near here.

In contrast, we calculate a late Miocene mean $\delta^{18} \mathrm{O}$ soil water $\left(\delta^{18} \mathrm{O}_{\text {sw }}\right)$ value of $-3.9 \pm 1.2$ \%o (VSMOW) from pedogenic carbonate data (Kingston 1999), and hippo $\delta^{18} \mathrm{O}_{\mathrm{bw}}$ values ranging from -4.8 to $-0.2 \%$ (median $-2.7 \%$, VSMOW). Taken together, reconstructed soil water and hippo body water values indicate that late Miocene precipitation was more negative than modern values by $\sim 4 \%$. As a caveat however, in some cases, such as in arid environments or closed lakes, the $\delta^{18} \mathrm{O}$ of water and thus of hippo body water does not necessarily reflect precipitation because of evaporative enrichment.

\section{Discussion}

\subsection{Paleoenvironmental reconstructions in local and regional contexts}

\subsubsection{Baynunah vegetation from carbon isotopes}

The plant wax carbon isotope data from $n$-alkanes and fatty acids show good agreement between the two classes of plant waxes and indicate mostly mixed $\mathrm{C}_{3}-\mathrm{C}_{4}$ ecosystems, which likely comprised grassy woodland or bushland to wooded or bushy grasslands (Fig. 18.4). The plant wax carbon isotope data agree well with that from pedogenic carbonate and also from diet-based reconstructions from enamel. All point to mixed $\mathrm{C}_{3}-\mathrm{C}_{4}$ ecosystems. Carbon isotope data from plant waxes and pedogenic carbonate indicate ranges of 27 to $73 \% \mathrm{C}_{4}$ and 16 to $63 \% \mathrm{C}_{4}$, 
respectively (Table 18.8). Two-thirds of the sampled large herbivore teeth indicate mixed $\mathrm{C}_{3}-\mathrm{C}_{4}$ to $\mathrm{C}_{4}$-dominated diets (Fig. 18.7), further supporting the plant wax and pedogenic carbonate data.

Table. 18.8 near here.

We evaluate the vegetation signals from sites where multiple carbon isotope proxy data are available (Hamra, Kihal, Jebel Barakah, Shuwaihat, and Ruwais) to explore the range of possible environments in the Baynunah (Table 18.8). Temporal and stratigraphic correlation between Baynunah localities is problematic owing to the difficulties of precisely dating the sediments and to the heterogeneous nature of fluvial sediments in a variable, broad depositional system (Friend 1999; Schuster this volume). The localities are all broadly contemporaneous, however, and differences in reconstructed vegetation therefore likely reflect spatial landscape heterogeneity over the timescale of deposition, which may have been on the order of 200 to 700 kyr for the entire Baynunah Formation (Peppe et al. this volume).

Localities at Kihal (KIH 2) and Hamra (HMR 5) both yielded multiple plant wax and pedogenic carbonate samples that indicate mixed vegetation (16 to $62 \% \mathrm{C} 4$, Table 18.8 ). Tooth enamel data from Hamra (HMR 1, 2, $3,5,6$ ) and Kihal (KIH 1 and UL) similarly indicate a wide range of diets ( 2 to $79 \% \mathrm{C}_{4}$ and 62 to $82 \% \mathrm{C}_{4}$, respectively). The median dietary values from these localities $\left(65 \% \mathrm{C}_{4}\right.$ and $\left.72 \% \mathrm{C}_{4}\right)$, are in good agreement with the higher end of ${ }_{0} \mathrm{C}_{4}$ estimates from the plant wax and pedogenic carbonate data from those same sites. At the westernmost sampling point, Jebel Barakah, pedogenic carbonate data indicate 32 to $55 \% \mathrm{C}_{4}$ vegetation whereas enamel data suggest 40 to $84 \% \mathrm{C}_{4}$ vegetation in diets. A single pedogenic carbonate sample from Shuwaihat shows $63 \% \mathrm{C}_{4}$ vegetation, where a large sample of enamel 
indicates diets ranged from 0 to $78 \% \mathrm{C}_{4}(\mathrm{SHU} 1,2$, and 4). A single plant wax sample from Ruwais (RUW SE) yielded the most negative $\delta^{13} \mathrm{C}_{\text {alkane }}$ value, representing an estimated $27 \% \mathrm{C}_{4}$ vegetation. In contrast, a single hippo from this site had a mixed but mostly $\mathrm{C}_{4} \operatorname{diet}(67 \%)$. Finally, at Mleisa (MLS1), the site of a proboscidean herd trackway (Bibi et al. 2012; Bibi et al. this volume-c), a single plant wax sample indicates $73 \% \mathrm{C}_{4}$, the highest recorded value in the Baynunah. The most abundant proboscidean and most likely to be found in the open environment at Mleisa is S. emiratus (Bibi et al. 2012; Sanders this volume), which has a median diet of $65 \% \mathrm{C}_{4}$. Mazzini and Kovacova (this volume) reconstruct the Mleisa (MLS1) trackway site as a low energy, non-marine, seasonally-inundated plain based on ostracod and charophyte fossil remains. Such a brackish, fluctuating wet-dry environment may have supported $\mathrm{C}_{4}$ sedges, grasses, or halophytic $\mathrm{C}_{4}$ shrubs (e.g., Amaranthaceae or Chenopodiaceae). Sedimentological evidence also points to periodic drying of the carbonate-rich sediment based on desiccation cracks (Bibi et al. 2012).

\subsubsection{Old World vegetation from carbon isotopes}

Vegetation reconstructions from carbon isotopes in pedogenic carbonates enable a direct comparison of Baynunah ecosystems with those of contemporaneous sites in South Asia (the Siwaliks) and in eastern Africa (Lothagam) (Fig. 18.9). The timing and rate of spread of $\mathrm{C}_{4}$ vegetation differ between Africa and South Asia. The onset of the $\mathrm{C}_{4}$ expansion in Africa started at $\sim 10 \mathrm{Ma}$, whereas $\mathrm{C}_{4}$ vegetation spread more rapidly in South Asia than in Africa, starting at 7.5 Ma (Behrensmeyer et al. 2007; Feakins et al. 2013; Polissar et al. 2019; Quade et al. 1989; Uno et al. 2016a). The age uncertainty of the Baynunah Formation precludes comparisons about the timing and rate of diet and ecosystem change in relation to these other sites, but the carbon 
isotope data still provide a basis for paleoenvironmental comparisons, particularly as concerns the degree of local woody cover. Data were compiled from all sites ranging from 8 to $6 \mathrm{Ma}$ (Behrensmeyer et al. 2007; Cerling et al. 2003a; Kingston 1999), updated to the GPTS of Gradstein and Ogg (2012) where relevant, and converted to fraction woody cover (fwc) using the equation of Cerling et al. (2011) (Fig. 18.10). As a functional classification, Cerling et al. (2011) used $>80 \%$ woody cover to denote forest habitats, $80-40 \%$ as (grassy) woodland, bushland, or shrubland, $40-10 \%$ as woody grasslands, and $<10 \%$ as grasslands. The data indicate that Baynunah and Lothagam were similar to each other, with 74 and $76 \%$ of sample values, respectively, indicating woody grasslands, and ca. $5 \%$ of values indicating grasslands (Table 18.9). Only $c a .25 \%$ of values at these sites have $f w c>40 \%$. In contrast, during the same late Miocene interval in the Siwaliks, more than $72 \%$ of the data indicate woody-dominated ecosystems (fwc $>40 \%$ ), with woody grasslands and grasslands making up only 24 and $4 \%$ of samples, respectively (Figure 18.10).

Fig. 18.9 near here. Width $=$ full page.

Fig. 18.10 near here. Width $=$ half page

Table 18.9 near here

\subsubsection{Hydroclimate Evidence for Monsoon Conditions}

The climate of the Baynunah region today is characterized by warm temperatures and very low mean annual precipitation that results in a hyperarid ecosystem incapable of supporting the diversity of large mammals that lived there during the late Miocene. Conditions during the late 
Miocene were clearly much wetter than present and the ensuing discussion aims to provide isotopic evidence for a wetter and highly seasonal climate.

The late Miocene $\delta^{18} \mathrm{O}_{\mathrm{sw}}$ value, which is a maximum estimate of the $\delta^{18} \mathrm{O}_{\text {precip }}$ due to soil water evaporation, is $4 \%$ more negative than the estimated modern-day $\delta^{18} \mathrm{O}_{\text {precip }}$ (Table 18.7). There are three major mechanisms that could lead to such a difference between late Miocene and modern $\delta^{18} \mathrm{O}$ values. The first is the amount effect, whereby higher mean annual precipitation (MAP) results in lower $\delta^{18} \mathrm{O}_{\text {precip }}$ values (Dansgaard 1964). The second is what is often called the continental effect, whereby an increase in the distance between the site of precipitation and the source water results in a decrease in the $\delta^{18} \mathrm{O}_{\text {precip }}$ value through Rayleigh distillation (Dansgaard 1964). The third mechanism is changes in the temperature of source water (i.e., sea surface temperature), which affects the fractionation factor between liquid and vapor during evaporation.

The amount effect, or higher MAP, is the most likely cause for the more negative $\delta^{18} \mathrm{O}$ values in the late Miocene. The amount effect is the dominant control on isotopic variability in precipitation at low latitudes, where mean annual temperature variability is small and therefore the temperature effect on the $\delta^{18} \mathrm{O}_{\text {precip }}$ is low. Multiple lines of evidence supporting our interpretation of the oxygen isotope values as indicative of higher MAP include geological, paleontological, modeling, and geochemical data. The fluvial deposits of the Baynunah Formation provide evidence for a variable but primarily low energy, braided river system, which requires regionally wetter conditions than present (Friend 1999; Schuster this volume). Other sedimentary facies, such as ostracod rich carbonate muds at Mleisa, provide evidence for local, seasonally inundated fresh to brackish environments (Mazzini and Kovacova this volume). The assemblage of large mammals and the associated ecosystems required to support their diet and water needs also point to higher rainfall in the region. 
Vegetation reconstructions also provide clues about the rainfall regime of the Baynunah sites. Modern savannas are a good analogue for the mixed $\mathrm{C}_{3}-\mathrm{C}_{4}$ ecosystems that existed in the Baynunah. In modern African savannas-ecosystems that are the closest geographically and floristically to the Arabian Peninsula-MAP ranges from $\sim 150$ to $1200 \mathrm{~mm}$ (Sankaran et al. 2005), which provides a general constraint for the late Miocene Baynunah. In contrast, modern Abu Dhabi Emirate receives significantly less than $100 \mathrm{~mm}$ MAP today. A late Miocene climate model by Tang et al. (2011) suggested that annual and seasonal temperature and precipitation values in the late Miocene were not greatly different from those today, with perhaps slightly wetter summers and slightly drier winters. A more recent model by Zhang et al. (2014) suggests higher MAP in Baynunah times as a result of a more northerly positioned Intertropical Convergence Zone in the late Miocene; in their study, the Baynunah region is crossed by a 800 mm MAP isopleth (and bounded between 400 to $1200 \mathrm{~mm}$ MAP isopleths), which is within the range of modern savanna ecosystems and therefore seems a reasonable estimate for the late Miocene Baynunah. Increased rainfall over this part of the Arabian Peninsula may have also occurred much more recently. A Pleistocene reconstruction of Arabian paleoprecipitation from an ensemble of GCM models suggests a MAP of 200 to $600 \mathrm{~mm}$ for western Abu Dhabi Emirate during the last interglacial, $130 \mathrm{ka}$ (Jennings et al. 2015).

Whereas multiple lines of evidence suggest higher precipitation in the late Miocene, there is less support for the other two mechanisms that might explain lower $\delta^{18} \mathrm{O}$ values. Changes in the vapor source or transport distance were likely minimal because there have not been changes in regional paleogeography since the late Miocene that would significantly affect the distance of the Baynunah region to the Arabian Sea and Indian Ocean, which were likely the main moisture sources for precipitation (Fig. 18.9 and see figure 9 in Popov et al. 2004). Therefore, we rule out 
the influence of vapor transport distance on the changes in $\delta^{18} \mathrm{O}$ values. The third possible mechanism, a change in source water temperature, is not likely responsible for the observed $\delta^{18} \mathrm{O}$ values. This would require cooler SSTs when in fact Arabian Sea SSTs were about $2-3^{\circ} \mathrm{C}$ warmer in the late Miocene compared to present (Huang et al. 2007; Zhuang et al. 2017).

The intratooth oxygen isotope profiles and the inverse model results from equid teeth provide new and important information that support a highly seasonal, monsoonal precipitation regime. We interpret the intratooth profile data from the Baynunah equids as indicating a single rainy season represented by more negative $\delta^{18} \mathrm{O}_{\text {enamel }}$ values, followed by a long dry season with more positive $\delta^{18} \mathrm{O}_{\text {enamel }}$ values (Fig. 18.8). This interpretation fits the relationship observed in other studies where the amount effect is dominant. In a study of modern equids, Blumenthal et al. (2019) show that the $\delta^{18} \mathrm{O}_{\text {enamel }}$ range in intratooth profiles scales with the $\delta^{18} \mathrm{O}$ range in precipitation in low latitudes. Lower $\delta^{18} \mathrm{O}$ precipitation values in the tropics generally correspond to wet seasons. The modern equid data support this interpretation of the Baynunah data.

The corresponding equid $\delta^{13} \mathrm{C}_{\text {enamel }}$ profiles in turn reveal increased $\mathrm{C}_{4}$ feeding during the wet season - presumably the preferred diet - and increased $\mathrm{C}_{3}$ feeding during the dry season presumably the fall-back resource (Fig. 18.8). The modeled intratooth $\delta^{18} \mathrm{O}_{\text {enamel }}$ ranges are very high, approaching $11 \%$, indicating strong seasonality. These isotopic data cannot simply be converted to absolute rainfall values, but the measured range of $\delta^{18} \mathrm{O}_{\text {enamel }}$ values in Baynunah equids $(4.7 \pm 0.9 \%)$ is more than $2 \%$ greater than the range observed in coeval ( 8 to $6 \mathrm{Ma}$ ) profiles from equid teeth from the Siwaliks (2.6 $\pm 0.8 \%$; (Nelson 2005). This suggests much greater seasonality of precipitation in the Baynunah than in the Potwar Plateau of Pakistan during the late Miocene. While seasonal variability in the $\delta^{18} \mathrm{O}$ values of meteoric water likely 
dominate the $\delta^{18} \mathrm{O}_{\text {enamel }}$ profiles, other factors such as changes in water source related to dietary change or animal physiology and behavior likely play a secondary role.

Oxygen isotope data from bulk tooth enamel provide further evidence for strong seasonality (Fig. 18.7). There is a nearly $12 \%$ difference between the median values of the water-dependent hippos (low $\delta^{18} \mathrm{O}_{\text {enamel }}$ ), and the less water-dependent giraffids (high $\delta^{18} \mathrm{O}_{\text {enamel }}$ ). Following the terminology of Levin et al. (2006), hippos are an evaporation insensitive (EI) taxon whose $\delta^{18} \mathrm{O}_{\mathrm{bw}}$ values most closely track meteoric water, whereas giraffes are an evaporation sensitive (ES) taxon whose $\delta^{18} \mathrm{O}_{\mathrm{bw}}$ values are sensitive to aridity because a high fraction of their ingested water comes from leaf water that is subject to evaporative enrichment of ${ }^{18} \mathrm{O}$ by local aridity. The high $\delta^{18} \mathrm{O}_{\text {enamel }}$ values of the giraffes stand out among other taxa in the Baynunah because it is the only ES lineage at the site (discussed below). Furthermore, the giraffe data stand out because most of the sampled teeth show mixed or $\mathrm{C}_{4}$ diets that differ from extant giraffe diet and because they all come from the same site (RDB 2), so their anomalously high $\delta^{18} \mathrm{O}_{\text {enamel }}$ values may reflect a highly localized signal. Thus, we refrain from applying the updated equation for calculating water deficit (WD) from Blumenthal et al. (2017) to the Baynunah enamel data. However, we note that the $\sim 12 \%$ difference between ES and EI $\delta^{18} \mathrm{O}_{\text {enamel }}$ is similar to that for the Lake Turkana (Kenya) region today, where WD is $c a .2300 \mathrm{~mm} / \mathrm{yr}$. The large $\delta^{18} \mathrm{O}_{\text {enamel }}$ offset between ES and EI taxa demonstrates the Baynunah environment was characterized by high aridity, further supported by the large amplitude in the equid intratooth profiles.

We interpret the evidence for highly seasonal precipitation as indications of a welldeveloped monsoon. The presence of a single wet season is more like the situation seen today in the African Sahel or parts of the Indian Peninsula, rather than the dual rainy season of modern East Africa. The monsoonal climate would have exerted major controls on the local vegetation 
structure, with long dry seasons and concentrated precipitation resulting in a high abundance of $\mathrm{C}_{4}$ grasses and low fraction of woody cover (Good et al. 2011). Together, the intratooth carbon and oxygen isotope profiles provide evidence for the presence of intense, monsoon-style hydroclimate seasonality, with significant seasonal changes in vegetation.

Finally, the equid intratooth profiles from Baynunah and the Siwaliks indicate that in both regions a monsoon system exerted primary control of hydroclimate. The seasonality of precipitation was stronger at Baynunah based on the intratooth amplitude of $\delta^{18} \mathrm{O}$. Intratooth profiles from coeval African Lothagam fauna could help constrain seasonality there during the late Miocene. Precipitation amounts at Baynunah are estimated at $\sim 800 \mathrm{~mm} / \mathrm{yr}$ based on regional climate models (Zhange et al. 2014), whereas at Lothagam, the ecometric approach suggests a MAP of $900 \pm 500 \mathrm{~mm}$ (Fortelius et al. 2016).

\subsection{Dietary reconstructions in local and global contexts}

The Baynunah tooth enamel carbon isotope data indicate a wide range of diets among Proboscidea, Perissodactyla, and Artiodactyla, including species with $\mathrm{C}_{3}$-dominated, mixed $\mathrm{C}_{3^{-}}$ $\mathrm{C}_{4}$, and $\mathrm{C}_{4}$-dominated diets at Baynunah. The majority of species have mixed $\mathrm{C}_{3}-\mathrm{C}_{4}$ or $\mathrm{C}_{4}{ }^{-}$ dominated diets, which generally agrees with the grassy woodland (or bushland) to woody (or bushy) grassland ecosystems reconstructed from the plant wax and pedogenic carbonate isotopes. Carbon isotope data show a range of $14 \%$ and the oxygen isotope data a range of $\sim 17 \%$ across Baynunah fauna. Under the vegetation and hydroclimate framework discussed above, we discuss dietary reconstructions for the Baynunah ungulates, using oxygen isotope data to further evaluate water use, reliance, and relevance to diet. These data are contextualized through comparison with published enamel isotope data of other late Miocene (8-6 Ma) faunas from the Siwaliks (Potwar Plateau, Pakistan), Lothagam (Turkana Basin, Kenya), and Toros Menalla, Chad, all of which 
have varying degrees of taxonomic affinities to the Baynunah fauna (Figs. 18.9 and 18.11). We focus our comparison of Baynunah enamel isotope data primarily to Lothagam and the Siwaliks, from where the largest data sets are available (Badgley et al. 2008; Uno et al. 2011). For the $\delta^{18} \mathrm{O}$ data reported in Badgley et al. (2008), we were unable to verify whether or not some or all values were calculated using the temperature dependent acid fractionation factor determined for enamel as was done for the values presented from Baynunah (this study) and Lothagam (Uno et al. 2011). Furthermore, we also caution that due to limited sample size of enamel powders, Lothagam enamel samples were not pretreated the way that samples from Baynunah and presumably Badgley et al. (2008) were. Thus, there may be $\delta^{18} \mathrm{O}$ offsets of up to $\sim \pm 2 \%$ relative to treated samples.

\subsubsection{Artiodactyls}

While at least eight species of Bovidae are present in the Baynunah fauna (Bibi this volume) only two species were sampled, the $\mathrm{C}_{3}$-dominated to mixed feeding Tragoportax cyrenaicus and the mixed to $\mathrm{C}_{4}$-dominated feeding Pachyportax latidens. Together, these two large species span a wide range of the $\mathrm{C}_{3}-\mathrm{C}_{4}$ dietary spectrum. These two species had diets more similar to bovids from Lothagam (Fig. 18.11) than from the Siwaliks, despite closer taxonomic affinities with the latter. In the Siwaliks, bovids from 8 to 6 Ma still had mostly $\mathrm{C}_{3}$-dominated to mixed diets, with only a few having $\mathrm{C}_{4}$-dominated diets and almost none having the mixed diets observed at Baynunah (Fig. 18.11). Tragoportax pilgrimi from the Siwaliks had a $\mathrm{C}_{3}$-dominated diet from $\sim 8.5$ to 8 Ma but from 7.3 Ma onwards shows a mixed to $\mathrm{C}_{4}$-dominated diet. Limited data from three Pachyportax samples from the Siwaliks, all from 7.3 Ma, show it was a mixed

feeder (Badgley et al. 2008). Baynunah bovid $\delta^{18} \mathrm{O}$ values fall closer to those of the Siwaliks than those from Lothagam (Fig. 18.11). One might interpret this as slightly more mesic environments 
in the Siwaliks and more arid at Lothagam, but it could be the result of different source water values in each region.

Extant giraffids are represented by Giraffa and Okapia, both dedicated browsers. The Baynunah giraffids, in contrast, include the earliest evidence for $\mathrm{C}_{4}$ grazing in a giraffid. Kingston (1999) previously discussed this observation, and here we add two additional sivathere specimens (AUH 204 and AUH 1124) that confirm that these early large giraffids had $\mathrm{C}_{4}{ }^{-}$ dominated diets. The median oxygen isotope value for the Baynunah sivatheres $(+4.3 \%)$ is 9 $\%$ more positive than the median value for all other Baynunah large mammals $(-4.7 \%$; Fig. 18.7), which indicates a major difference in physiology or water-use strategy from the other Baynunah large mammals, a pattern observed at other late Miocene sites (Domingo et al. 2017). One possible mechanism that would lead to the high $\delta^{18} \mathrm{O}$ values is that these sivatheres may have ingested most of their water from evaporated leaf water or drank from an evaporated water source. The other sampled giraffid, tentatively assigned to Palaeotragus aff. germaini or cf. Samotherium, had a $\mathrm{C}_{3}$-dominated diet, similar to those at Lothagam and in the Siwaliks (Fig. 18.11), but also a very high $\delta^{18} \mathrm{O}_{\text {enamel }}$ value. The elevated $\delta^{18} \mathrm{O}_{\text {enamel }}$ values observed in these fossil giraffids suggests that they obtained most of their water intake from plant water, as is observed in modern giraffes. All Baynunah giraffids come from the Ras Dubay'ah 2 (RDB 2) locality, which alternately might have been more arid relative to other Baynunah sites. Equids from Ras Dubay'ah also show high oxygen isotope values relative to those from all other sites (difference of $\sim 4.5 \%$ ), supporting this notion.

The Baynunah hippopotamid, Archaeopotamus qeshta, has the most $\mathrm{C}_{4}$-rich diet of all the taxa sampled (Fig. 18.7). Extant Hippopotamus feeds along the banks or floodplains of aquatic systems, often on $\mathrm{C}_{4}$ grasses and under the cover of night. Perhaps a similar scenario unfolded 
along the banks of the Baynunah river system. The Baynunah hippopotamids also exhibit the narrowest dietary range of all the Baynunah large mammals sampled, and narrower than the range exhibited by hippopotamids at other contemporaneous sites (Fig. 18.11). At both Lothagam and Toros-Menalla, hippopotamids maintained much wider dietary ranges and more mixed $\mathrm{C}_{3}-\mathrm{C}_{4}$ diets (Boisserie et al. 2005; Uno et al. 2011). Finally, we note that the Baynunah hippos exhibit the lowest $\delta^{18} \mathrm{O}$ values of all fauna, more than $3.5 \%$ more negative than the median value of all non-hippo taxa, providing strong support for a semi-aquatic lifestyle in early hippopotamines. The isotope date from the Baynunah hippos support the idea of the Hippopotamine Event around $8 \mathrm{Ma}$, which saw the diversification of hippopotamids into aquatic habitats and $\mathrm{C}_{4}$ diets (Boisserie and Merceron 2011; Boisserie and Bibi this volume).

The suids are the only Baynunah artiodactyl with a $\mathrm{C}_{3}$-dominated diet. Only three samples representing two species, Nyanzachoerus syrticus and Propotamochoerus hysudricus, were analyzed but all fall squarely within the $\mathrm{C}_{3}$ range. Coeval late Miocene suids from the Siwaliks, which also include the taxon $P$. hysudricus, were also almost all $\mathrm{C}_{3}$ feeders (Badgley et al. 2008). In contrast, lower Nawata suids, comprised primarily of Nyanzachoerus spp., had some $\mathrm{C}_{3}$-dominated but mostly mixed diets (Uno et al. 2011; Fig. 18.11). Thus, the diets of the Baynunah Suidae were more similar to their South Asian counterparts.

\subsubsection{Perissodactyls}

Equids are common in the Baynunah, with nearly 200 specimens recovered from multiple sites and they comprise over a third of the isotope data set. They are represented by at least two species, "Hipparion" abudhabiense and a second small "Hipparion" (Bernor et al. this volume). Baynunah equids have a highly variable diet (24 to $\left.84 \% \mathrm{C}_{4}\right)$, with most sampled individuals 
falling into the mixed diet category. Median $\delta^{13} \mathrm{C}$ values are similar to those of $S$. emiratus and A. qeshta. The intratooth profiles from six cheek teeth show that they had seasonally variable diets that ranged from 22 to $97 \% \mathrm{C} 4$ after taking enamel maturation and sampling geometry into consideration. The profiles suggest consumption of $\mathrm{C}_{4}$ grasses was highest during the wet season, as indicated by a general inverse relationship between the carbon and oxygen intratooth profiles (Fig. 18.8).

The diet of the Baynunah equids falls between that of Siwaliks and Lothagam equids (Fig. 18.11). From 8 to 7 Ma, Siwaliks equids relied more on browsing (or $\mathrm{C}_{3}$ grazing) than those in the Baynunah, whereas African equids were nearly all $\mathrm{C}_{4}$ grazers by this time. In late Neogene fossil localities around the world, including East Africa, South Asia, and North America, equids serve as the "first responders" to $\mathrm{C}_{4}$ vegetation on the landscape (Morgan and Kingston 1994; Passey et al. 2002; Uno et al. 2011). Although tempting, it is not possible to estimate the age of the Baynunah fauna based on the amount of $\mathrm{C}_{4}$ vegetation in their diets. The timing of initiation and rate of spread of $\mathrm{C}_{4}$ ecosystems varied significantly across continents between 10 and $3 \mathrm{Ma}$ and as a result, the first indication of significant $\mathrm{C}_{4}$ vegetation $(>50 \%)$ in equid diets is also varied. It occurs in Africa at $\sim 10 \mathrm{Ma}$, in the Siwaliks around $8.7 \mathrm{Ma}$, and in North America around 6.1 Ma (Badgley et al. 2008; Nelson 2005; Passey et al. 2002; Uno et al. 2011).

Rhinocerotids are very rare in the Baynunah Formation. The two tooth fragments analyzed from Shuwaihat (SHU 1) indicate it was one of the few taxa that had a nearly pure $\mathrm{C}_{3}$ diet. Both fragmentary specimens were found within a year of each other (1989 and 1990) at the same site and have similar carbon and oxygen values, so it is possible they represent the same individual. The diet of the Baynunah rhinocerotid(s) was similar to the browsing forms at 
Lothagam that included Brachypotherium lewisi, Ceratotherium sp., and Diceros praecox (Uno et al. 2011).

\subsubsection{Proboscideans}

The dominant proboscidean in the Baynunah, Stegotetrabelodon emiratus, had a mixed to $\mathrm{C}_{4}{ }^{-}$ dominated diet. Elephantidae and Gomphotheriidae from the Lower Nawata at Lothagam also had mixed $\mathrm{C}_{3}-\mathrm{C}_{4}$ diets, but by the Upper Nawata $(\sim 6.5 \mathrm{Ma})$ had all shifted to $\mathrm{C}_{4}$-dominated diets (Fig. 18.11). The single gomphothere specimen from Baynunah had a diet that was broadly similar to $S$. emiratus, but with less $\mathrm{C}_{4}(48 \%)$ than its Lower Nawata counterparts. Baynunah deinotheres, like those from Lothagam and the Siwaliks ( $>8 \mathrm{Ma}$ ), had $\mathrm{C}_{3}$-dominated diets.

\subsubsection{Baynunah Dietary Structure}

It is interesting that the giraffids, hippopotamids, equids, and elephantids, which together account for $80 \%$ of the samples analyzed, show such high overlap of their carbon isotope values (Fig. 18.7), suggesting significant overlap of their dietary niches. Intratooth carbon isotope profiles reveal that the equids had seasonally variable diets, and the range of carbon isotope values in elephants suggests this may have been the case there too (Fig. 18.6). In contrast, the narrow range of hippopotamid values suggests their diets were less variable throughout the year. The giraffids occupied both grazing and mixed feeding to browsing niches, but it is not clear if seasonal variations in diet may have been present. Intratooth profiles would be useful in this regard. What is clear is the strong separation between the $\mathrm{C}_{3}$-dependent (browsing) cladesdeinotheriids, suids, and rhinocerotids — and the mixed feeding to graze-dominated giraffids, bovids, hippopotamids, proboscideans, and equids (Fig. 18.6). The three browsers are all very 
rare in terms of number of identified specimens, while the mixed-feeding to grazing ungulates (particularly equids and hippopotamids) are far more abundant (Bibi et al. this volume). This suggests that the landscape was likely a wooded grassland, as indicated also by the pedogenic carbonate and plant wax $\delta^{13} \mathrm{C}$ values.

The dietary structure of Baynunah large mammals is more similar to Lothagam than the Siwaliks. Lothagam is dominated by mixed feeding to graze-dominated herbivores, whereas the Siwaliks at that time still had large $\mathrm{C}_{3}$-dominated (browsing) herbivores, represented by suids and bovids, and some mixed feeders. Equid intratooth profiles from Baynunah and the Siwaliks indicate that in both regions a monsoon system exerted primary control of hydroclimate. The seasonality of precipitation was stronger at Baynunah based on the intratooth amplitude of $\delta^{18} \mathrm{O}$. Intratooth profiles from coeval African fauna could help constrain seasonality there during the late Miocene.

\section{Conclusions}

Our findings indicate $\mathrm{C}_{4}$ grasses were an important part of Baynunah ecosystems, and at an age of around $7 \mathrm{Ma}$, the Baynunah represents one of the earliest wooded grasslands, or mixed $\mathrm{C}_{3}-\mathrm{C}_{4}$ to $\mathrm{C}_{4}$-dominated ecosystems, known to date. The strong reliance of the most abundant large mammal clades on $\mathrm{C}_{4}$-feeding, even if only seasonally, indicates large mammals were already well-adapted to (and almost certainly co-evolved with) $\mathrm{C}_{4}$ grasses by this time. The strong, monsoonal-type rainfall seasonality revealed by the equid intratooth isotope profiles describe an ideal environment for the proliferation of $\mathrm{C}_{4}$ grasses.

The dominance of grasses however did not preclude the presence of woody vegetation and cover, as at least one giraffid, two suids, a deinotherid, and a rhinocerotid subsisted entirely 
on $\mathrm{C}_{3}$ resources, most likely browse. The resulting 'mosaic' of grasslands and trees is typical for the diversity of habitats collectively referred to as savannas, which today are characteristic of much of sub-Saharan Africa, and during the late Miocene were widespread across Afro-Arabia and large tracts of Eurasia (Fortelius et al. 2002; Kaya et al. 2018).

\section{Acknowledgements}

This work was supported by the Abu Dhabi Department of Culture and Tourism (formerly TCA, formerly ADACH) and the US National Science Foundation (grants OISE-0852975 to FB, and 0321893 - RHOI - to T. White and F. C. Howell). We acknowledge and thank the many scientists who conducted field work and lab work to build the collection of fossil teeth sampled in this study and who identified and described the outcrops where sediments were sampled for compound specific isotope analyses of plant waxes. We thank Mark Franklin and Natalia Galud Erazo for assistance with sampling, pretreatment, and weighing of enamel samples for isotope analysis and Wei Huang for assistance with mass spectrometry. We also thank Gertrud Rössner and the BSPG (Munich) for providing an enamel sample of BSPG 1965 I112. We thank Drs. Laura Domingo and Naomi Levin for thorough reviews which helped improve the manuscript. KTU thanks Michelle Morgan and Sherry Nelson for providing published Siwaliks enamel isotope data in electronic format and John Kingston for providing Baynunah enamel and pedogenic carbonate isotope data in electronic format. This is Lamont-Doherty Earth Observatory contribution \#8487. 


\section{Figures: 1 through 9}

Figure 18.1. Location of Baynunah Formation localities (circles) in the Al Dhafra region, western Abu Dhabi Emirate, United Arab Emirates. Sites are coded by color based on isotopic sample type (PW, plant wax; EN, enamel; PC, pedogenic carbonate). Modified from (Bibi et al. 2013).

[1.5 column width]

Figure 18.2. Modern monthly temperature (gray bars) and precipitation (blue line) of Abu Dhabi from 1971 to 1991 (NOAA 2018). [single column width]

Figure 18.3. Normalized plant wax concentrations for $n$-alkanes and $n$-alkanoic acids at different sites of the Baynunah Formation (all contemporaneous). [full page]

Figure 18.4. Plant wax $\delta^{13} \mathrm{C}$ values for $n$-alkanes and $n$-alkanoic acids (\%o, VPDB). [full page width]

Figure 18.5. Cross-plot of carbon and oxygen isotope values for treated vs. untreated tooth enamel (\%o, VPDB). [full page width]

Figure 18.6. Cross-plot of fossil enamel carbon and oxygen isotope values (\%o, VPDB) for nine mammalian families. Data include isotope values from Kingston (1999). [single column width]

Figure 18.7. Carbon and oxygen isotope box plots by family. Carbon isotope data show that most taxa are mixed feeders but hippos are grazers and suids, rhinocerotids, and deinotherids are 
browsers. For oxygen isotopes, hippopotamid values are low, as expected for semi-aquatic habits, whereas giraffid values are high, indicating strong evaporative effects on plant water, evaporated drinking water, or a combination of both. Data include isotope values from Kingston (1999). [full page width]

Figure 18.8. Equid intratooth isotope profiles of carbon (left column) and corresponding oxygen isotope values (right column). In general, carbon and oxygen data covary out of phase with one another. H abu. is "Hipparion" abudhabiense. Open circles are smoothed measured values, lines represent modeled values, and shaded areas represent $\pm 2 \sigma$ of modeled values. [full page]

Figure 18.9. Late Miocene vertebrate fossil sites where large stable isotope data sets are available. Paleogeography is based on a 7 Ma plate reconstruction using the Ocean Drilling Stratigraphic Network's Plate Tectonic Reconstruction Service (http://www.odsn.de/odsn/services/paleomap/paleomap.html) and modern zoogeographic zones are from Holt et al.(2013). [full page width]

Figure 18.10. Cumulative distribution of fraction woody cover $(f w c)$ data derived from $\delta^{13} \mathrm{C}$ values of pedogenic carbonates from Baynunah (red circles), Lothagam (purple triangles), and the Siwaliks (gray squares) from 8-6 Ma. Data are from Cerling et al. 2003a; Kingston 1999; and Behrensmeyer et al. 2007. [single column width]

Figure 18.11. Box plots of Baynunah (white), Lothagam (gray; Nawata Formation ), Siwaliks (gray; late Miocene (8-6 Ma) data only ), and Toros Menalla (gray) carbon and oxygen isotope 
data from fossil enamel (Badgley et al. 2008; Boisserie et al. 2005; Cerling et al. 2003a;

Kingston 1999; Uno et al. 2011). [full page width] 


\section{References}

Baczynski, A. A., McInerney, F. A., Wing, S. L., Kraus, M. J., Morse, P. E., Bloch, J. I., Chung, A. H., and Freeman, K. H., 2016, Distortion of carbon isotope excursion in bulk soil organic matter during the Paleocene-Eocene thermal maximum: Geological Society of America Bulletin, v. 128, no. 9-10, p. 1352-1366.

Badgley, C., Barry, J. C., Morgan, M. E., Nelson, S. V., Behrensmeyer, A. K., Cerling, T. E., and Pilbeam, D., 2008, Ecological changes in Miocene mammalian record show impact of prolonged climatic forcing: Proceedings of the National Academy of Sciences, v. 105, no. 34, p. 12145-12149.

Barry, J. C., Morgan, M. E., Flynn, L. J., Pilbeam, D., Behrensmeyer, A. K., Raza, S. M., Khan, I. A., Badgley, C., Hicks, J., and Kelley, J., 2002, Faunal and environmental change in the late Miocene Siwaliks of northern Pakistan: Paleobiology, v. 28, no. S2, p. 1-71.

Behrensmeyer, A. K., Quade, J., Cerling, T. E., Kappelman, J., Khan, I. A., Copeland, P., Roe, L., Hicks, J., Stubblefield, P., Willis, B. J., and Latorre, C., 2007, The structure and rate of late Miocene expansion of $\mathrm{C} 4$ plants: Evidence from lateral variation in stable isotopes in paleosols of the Siwalik Group, northern Pakistan: Geological Society of America Bulletin, v. 119, no. 11-12, p. 1486-1505.

Bendrey, R., Vella, D., Zazzo, A., Balasse, M., and Lepetz, S., 2015, Exponentially decreasing tooth growth rate in horse teeth: implications for isotopic analyses: Archaeometry, v. 57, no. 6 , p. 1104-1124. 
Bernor, R. L., Beech, M., Bibi, F. (this volume). Equidae from the Baynunah Formation. In F. Bibi, B. Kraatz, M. Beech, \& A. Hill (eds.) Sands of Time: Late Miocene Fossils from the Baynunah Formation, U.A.E. (pp. xxx). Cham: Springe

Bibi, F. (this volume). Bovidae and Giraffidae from the Baynunah Formation. In F. Bibi, B. Kraatz, M. Beech, \& A. Hill (eds.) Sands of Time: Late Miocene Fossils from the Baynunah Formation, U.A.E. (pp. xxx). Cham: Springer.

Bibi, F., Hill, A., Beech, M., and Yasin, W., 2013, Late Miocene Fossils from the Baynunah Formation, United Arab Emirates, in Wang, X., Flynn, L. J., and Fortelius, M., eds., Fossil Mammals of Asia: Neogene Biostratigraphy and Chronology: New York, Columbia University Press p. 583-594.

Bibi, F., Kraatz, B., Craig, N., Beech, M., Schuster, M., and Hill, A., 2012, Early evidence for complex social structure in Proboscidea from a late Miocene trackway site in the United Arab Emirates: Biol Lett, v. 8, no. 4, p. 670-673.

Bibi, F., Kaya, F., Varela, S. (this volume-a). Paleoecology and Paleobiogeography of the Baynunah Fauna. In F. Bibi, B. Kraatz, M. Beech, \& A. Hill (eds.) Sands of Time: Late Miocene Fossils from the Baynunah Formation, U.A.E. (pp. xxx). Cham: Springer.

Bibi, F., Beech, M., Hill, A., Kraatz, B. (this volume-b). Fossil Localities of the Baynunah Formation. In F. Bibi, B. Kraatz, M. Beech, \& A. Hill (eds.) Sands of Time: Late Miocene Fossils from the Baynunah Formation, U.A.E. (pp. xxx). Cham: Springer.

Bibi, F., Kraatz, B., Beech, M., Hill, A. (this volume-c). Fossil Trackways of the Baynunah Formation. In F. Bibi, B. Kraatz, M. Beech, \& A. Hill (eds.) Sands of Time: Late Miocene Fossils from the Baynunah Formation, U.A.E. (pp. xxx). Cham: Springer. 
Blumenthal, S. A., Cerling, T. E., Chritz, K. L., Bromage, T. G., Kozdon, R., and Valley, J. W., 2014, Stable isotope time-series in mammalian teeth: in situ $\delta 18 \mathrm{O}$ from the innermost enamel layer: Geochimica et Cosmochimica Acta, v. 124, p. 223-236.

Bocherens, H., Koch, P., Mariotti, A., Geraads, D., and Jaeger, J., 1996, Isotopic biogeochemistry $\left({ }^{13} \mathrm{C},{ }^{18} \mathrm{O}\right)$ of mammalian enamel from African Pleistocene hominid sites: Palaios, v. 11, no. 4, p. 306-318.

Boisserie, J.-R., and Bibi, F. (this volume). Hippopotamidae from the Baynunah Formation. In F. Bibi, B. Kraatz, M. Beech, \& A. Hill (eds.) Sands of Time: Late Miocene Fossils from the Baynunah Formation, U.A.E. (pp. xxx). Cham: Springer.

Boisserie, J.-R., and Merceron, G., 2011, Correlating the success of Hippopotaminae with the C4 grass expansion in Africa: Relationship and diet of early Pliocene hippopotamids from Langebaanweg, South Africa: Palaeogeography, Palaeoclimatology, Palaeoecology, v. 308, no. 3-4, p. 350-361.

Boisserie, J.-R., Zazzo, A., Merceron, G., Blondel, C., Vignaud, P., Likius, A., Mackaye, H. T., and Brunet, M., 2005, Diets of modern and late Miocene hippopotamids: Evidence from carbon isotope composition and micro-wear of tooth enamel: Palaeogeography, Palaeoclimatology, Palaeoecology, v. 221, no. 1-2, p. 153-174.

Bowen, G. J., 2018, The Online Isotopes in Precipitation Calculator, version 3.1.

Bowen, G. J., and Revenaugh, J., 2003, Interpolating the isotopic composition of modern meteoric precipitation: Water Resources Research, v. 39, no. 10.

Bryant, J. D., Koch, P. L., Froelich, P. N., Showers, W. J., and Genna, B. J., 1996, Oxygen isotope partitioning between phosphate and carbonate in mammalian apatite: Geochimica et Cosmochimica Acta, v. 60, no. 24, p. 5145-5148. 
Bush, R. T., and McInerney, F. A., 2013, Leaf wax n-alkane distributions in and across modern plants: Implications for paleoecology and chemotaxonomy: Geochimica et Cosmochimica Acta, v. 117, p. 161-179.

Bush, R. T., and McInerney, F. A., 2015, Influence of temperature and $\mathrm{C}_{4}$ abundance on n-alkane chain length distributions across the central USA: Organic Geochemistry, v. 79, p. 65-73.

Cerling, T., and Harris, J., 1999, Carbon isotope fractionation between diet and bioapatite in ungulate mammals and implications for ecological and paleoecological studies: Oecologia, v. 120 , no. 3, p. 347-363.

Cerling, T., Harris, J., and Leakey, M., 2003a, Isotope paleoecology of the Nawata and Nachukui Formations at Lothagam, Turkana Basin, Kenya, in Leakey, M. G., and Harris, J. M., eds., Lothagam: The Dawn of Humanity in Eastern Africa: New York, Columbia University Press, p. 605-623.

Cerling, T., Harris, J., Leakey, M., and Mudidia, N., 2003b, Stable isotope ecology of Northern Kenya, with emphasis on the Turkana Basin, in Leakey, M. G., and Harris, J. M., eds., Lothagam: The Dawn of Humanity in Eastern Africa: New York, Columbia University Press, p. 583-603.

Cerling, T. E., Harris, J. M., Hart, J. A., Kaleme, P., Klingel, H., Leakey, M. G., Levin, N. E., Lewison, R. L., and Passey, B. H., 2008, Stable isotope ecology of the common hippopotamus: Journal of Zoology, v. 276, no. 2, p. 204-212.

Cerling, T. E., Wynn, J. G., Andanje, S. A., Bird, M. I., Korir, D. K., Levin, N. E., Mace, W., Macharia, A. N., Quade, J., and Remien, C. H., 2011, Woody cover and hominin environments in the past 6 million years: Nature, v. 476, no. 7358 , p. 51-56. 
Collister, J. W., Rieley, G., Stern, B., Eglinton, G., and Fry, B., 1994, Compound-specific $\delta^{13} \mathrm{C}$ analyses of leaf lipids from plants with differing carbon dioxide metabolisms: Organic Geochemistry, v. 21, no. 6, p. 619-627.

Corrigan, D., Kloos, C., O'Connor, C. S., and Timoney, R. F., 1973, Alkanes from four species of Sphagnum moss: Phytochemistry, v. 12, no. 1, p. 213-214.

Cranwell, P. A., Eglinton, G., and Robinson, N., 1987, Lipids of aquatic organisms as potential contributors to lacustrine sediments-II: Organic Geochemistry, v. 11, no. 6, p. 513-527.

Crowell-Davis, S. L., Houpt, K. A., and Carnevale, J., 1985, Feeding and drinking behavior of mares and foals with free access to pasture and water: Journal of animal science, v. 60 , no. 4 , p. $883-889$.

Dansgaard, W., 1964, Stable isotopes in precipitation: Tellus, v. 16, no. 4, p. 436-468.

Domingo, L., Domingo, M. S., Koch, P. L., Morales, J., and Alberdi, M. T., 2017, Carnivoran resource and habitat use in the context of a Late Miocene faunal turnover episode: Palaeontology, v. 60, no. 4, p. 461-483.

Eglinton, G., and Hamilton, R. J., 1967, Leaf Epicuticular Waxes: Science, v. 156, no. 3780, p. $1322-1335$.

Feakins, S. J., deMenocal, P. B., and Eglinton, T. I., 2005, Biomarker records of late Neogene changes in northeast African vegetation: Geology, v. 33, no. 12, p. 977-980.

Feakins, S. J., Levin, N. E., Liddy, H. M., Sieracki, A., Eglinton, T. I., and Bonnefille, R., 2013, Northeast African vegetation change over 12 my: Geology, v. 41, no. 3, p. 295-298.

Ficken, K. J., Li, B., Swain, D. L., and Eglinton, G., 2000, An n-alkane proxy for the sedimentary input of submerged/floating freshwater aquatic macrophytes: Organic Geochemistry, v. 31, no. 7, p. 745-749. 
Fortelius, M., Eronen, J., Jernvall, J., Liu, L., Pushkina, D., Rinne, J., Tesakov, A., Vislobokova, I., Zhang, Z., and Zhou, L., 2002, Fossil mammals resolve regional patterns of Eurasian climate change over 20 million years: Evolutionary Ecology Research, v. 4, no. 7, p. 1005-1016.

Fortelius, M., Žliobaitè, I., Kaya, F., Bibi, F., Bobe, R., Leakey, L., Leakey, M., Patterson, D., Rannikko, J., and Werdelin, L., 2016, An ecometric analysis of the fossil mammal record of the Turkana Basin: Philosophical Transactions of the Royal Society of London B: Biological Sciences, v. 371, no. 1698.

Freeman, K. H., and Colarusso, L. A., 2001, Molecular and isotopic records of C4 grassland expansion in the late miocene: Geochimica et Cosmochimica Acta, v. 65, no. 9, p. 14391454.

Freeman, K. H., Hayes, J. M., Trendel, J. M., and Albrecht, P., 1990, Evidence from carbon isotope measurements for diverse origins of sedimentary hydrocarbons: Nature (London), v. 343 , no. 6255 , p. $254-256$.

Fricke, H. C., and O'Neil, J. R., 1996, Inter-and intra-tooth variation in the oxygen isotope composition of mammalian tooth enamel phosphate: implications for palaeoclimatological and palaeobiological research: Palaeogeography, Palaeoclimatology, Palaeoecology, v. 126, no. 1, p. 91-99.

Friend, P., 1999, Rivers of the Lower Baynunah Formation, Emirate of Abu Dhabi, United Arab Emirates, in Whybrow, P. J., and Hill, A., eds., Fossil Vertebrates of Arabia: New Haven, Connecticut, Yale University Press,, p. 38-49.

Good, S. P., and Caylor, K. K., 2011, Climatological determinants of woody cover in Africa: Proc Natl Acad Sci U S A, v. 108, no. 12, p. 4902-4907. 
Hailwood, E. A., and Whybrow, P. J., 1999, Paleomagnetic correlation and dating of the Baynunah and Shuwaihat Formations, in Whybrow, P. J., and Hill, A., eds., Fossil Vertebrates of Arabia: New Haven, Connecticut, Yale University Press,, p. 28-37.

Hayes, J. M., Freeman, K. H., Popp, B. N., and Hoham, C. H., 1990, Compound-specific isotopic analyses; a novel tool for reconstruction of ancient biogeochemical processes: Organic Geochemistry, v. 16, no. 4-6, p. 1115-1128.

Hill, A., Whybrow, P. J., and Yasin, W., 1999, History of Paleontological Research in the Western Region of the Emirate of Abu Dhabi, United Arab Emirates, in Whybrow, P. J., and Hill, A., eds., Fossil Vertebrates of Arabia: New Haven, Connecticut, Yale University Press, p. 18-23.

Holt, B. G., Lessard, J.-P., Borregaard, M. K., Fritz, S. A., Araújo, M. B., Dimitrov, D., Fabre, P.-H., Graham, C. H., Graves, G. R., and Jønsson, K. A., 2013, An update of Wallace’s zoogeographic regions of the world: Science, v. 339, no. 6115, p. 74-78.

Hoppe, K. A., Stover, S. M., Pascoe, J. R., and Amundson, R., 2004, Tooth enamel biomineralization in extant horses: implications for isotopic microsampling: Palaeogeography, Palaeoclimatology, Palaeoecology, v. 206, no. 3-4, p. 355-365.

Huang, Y., Clemens, S. C., Liu, W., Wang, Y., and Prell, W. L., 2007, Large-scale hydrological change drove the late Miocene C4 plant expansion in the Himalayan foreland and Arabian Peninsula: Geology, v. 35, no. 6, p. 531-534.

Huertas, A. D., Iacumin, P., Stenni, B., Chillón, B. S., and Longinelli, A., 1995, Oxygen isotope variations of phosphate in mammalian bone and tooth enamel: Geochimica et Cosmochimica Acta, v. 59, no. 20, p. 4299-4305. 
IAEA/WMO, 2019. Global Network of Isotopes in Precipitation. The GNIP Database.

Accessible at: http://www.iaea.org/water

Jennings, R. P., Singarayer, J., Stone, E. J., Krebs-Kanzow, U., Khon, V., Nisancioglu, K. H., Pfeiffer, M., Zhang, X., Parker, A., and Parton, A., 2015, The greening of Arabia: Multiple opportunities for human occupation of the Arabian Peninsula during the Late Pleistocene inferred from an ensemble of climate model simulations: Quaternary International, v. 382, p. 181-199.

Kaya, F., Bibi, F., Žliobaite, I., Eronen, J. T., Hui, T., and Fortelius, M., 2018, The rise and fall of the Old World savannah fauna and the origins of the African savannah biome: Nature ecology \& evolution, v. 2, no. 2, p. 241.

Kim, S. T., and O'Neil, J. R., 1997, Equilibrium and nonequilibrium oxygen isotope effects in synthetic carbonates: Geochimica et Cosmochimica Acta, v. 61, no. 16, p. 3461-3475.

Kingston, J. D., 1999, Isotopes and environments of the Baynunal Formation, Emirate of Abu Dhabi, United Arab Emirates, in Whybrow, P. J., and Hill, A., eds., Fossil Vertebrates of Arabia: New Haven, CT, Yale University Press, p. 354-372.

Kingston, J. D., and Harrison, T., 2007, Isotopic dietary reconstructions of Pliocene herbivores at Laetoli: Implications for early hominin paleoecology: Palaeogeography, Palaeoclimatology, Palaeoecology, v. 243, no. 3-4, p. 272-306.

Kohn, M. J., Schoeninger, M. J., and Valley, J. W., 1996, Herbivore tooth oxygen isotope compositions: effects of diet and physiology: Geochimica et Cosmochimica Acta, v. 60, no. 20 , p. $3889-3896$.

Leakey, M., and Harris, J., 2003, Lothagam: The Dawn of Humanity in Eastern Africa, Columbia Univ Press. 
Levin, N. E., Cerling, T. E., Passey, B. H., Harris, J. M., and Ehleringer, J. R., 2006, A stable isotope aridity index for terrestrial environments: Proceedings of the National Academy of Sciences of the United States of America, v. 93, no. 30, p. 11201-11205.

Livingstone, D., and Clayton, W., 1980, An altitudinal cline in tropical African grass floras and its paleoecological significance: Quaternary Research, v. 13, no. 3, p. 392-402.

Luz, B., Kolodny, Y., and Horowitz, M., 1984, Fractionation of oxygen isotopes between mammalian bone-phosphate and environmental drinking water: Geochimica et Cosmochimica Acta, v. 48, no. 8, p. 1689-1693.

Mazzini, I. \& Kovacova, M. (this volume). Ostracods, charophytes, and pollen from the Baynunah Formation. In F. Bibi, B. Kraatz, M. Beech, \& A. Hill (eds.) Sands of Time: Late Miocene Fossils from the Baynunah Formation, U.A.E. (pp. xxx). Cham: Springer.

Metcalfe, J. Z., Longstaffe, F. J., Ballenger, J. A. M., and Haynes Jr, C. V., 2011, Isotopic paleoecology of Clovis mammoths from Arizona: Proceedings of the National Academy of Sciences, v. 108, no. 44, p. 17916-17920.

Morgan, M., and Kingston, J., 1994, Carbon isotopic evidence for the emergence of C4 plants in the Neogene from Pakistan and Kenya: Nature, v. 367, p. 162-165.

Mueller, K. E., Polissar, P. J., Oleksyn, J., and Freeman, K. H., 2012, Differentiating temperate tree species and their organs using lipid biomarkers in leaves, roots and soil: Organic Geochemistry.

Nelson, S. V., 2005, Paleoseasonality inferred from equid teeth and intra-tooth isotopic variability: Palaeogeography, Palaeoclimatology, Palaeoecology, v. 222, no. 1, p. 122144.

NOAA (National Oceanic and Atmospheric Administration), 2018. National Centers for Environmental Information: Climate Data Online. Accessible at: https://www.ncdc.noaa.gov/ 
Nott, C. J., Xie, S., Avsejs, L. A., Maddy, D., Chambers, F. M., and Evershed, R. P., 2000, nAlkane distributions in ombrotrophic mires as indicators of vegetation change related to climatic variation: Organic Geochemistry, v. 31, no. 2-3, p. 231-235.

Passey, B. H., and Cerling, T. E., 2002, Tooth enamel mineralization in ungulates; implications for recovering a primary isotopic time-series: Geochimica et Cosmochimica Acta, v. 66, no. 18, p. $3225-3234$.

Passey, B. H., Cerling, T. E., and Levin, N. E., 2007, Temperature dependence of oxygen isotope acid fractionation for modern and fossil tooth enamels: Rapid communications in mass spectrometry, v. 21 , no. 17 , p. 2853-2859.

Passey, B. H., Cerling, T. E., Perkins, M. E., Voorhies, M. R., Harris, J. M., and Tucker, S. T., 2002, Environmental change in the Great Plains; an isotopic record from fossil horses: Journal of Geology, v. 110, no. 2, p. 123-140.

Passey, B. H., Cerling, T. E., Schuster, G. T., Robinson, T. F., Roeder, B. L., and Krueger, S. K., 2005, Inverse methods for estimating primary input signals from time-averaged isotope profiles: Geochimica et Cosmochimica Acta, v. 69, no. 16, p. 4101-4116.

Passey, B. H., Levin, N. E., Cerling, T. E., Brown, F. H., and Eiler, J. M., 2010, Hightemperature environments of human evolution in East Africa based on bond ordering in paleosol carbonates: Proceedings of the National Academy of Sciences, v. 107, no. 25, p. 11245.

Peppe, D. J., Evans, D. A. D., Beech, M., Hill, A., Bibi, F. (this volume). Magnetostratigraphy of the Baynunah Formation. In F. Bibi, B. Kraatz, M. Beech, \& A. Hill (eds.) Sands of Time: Late Miocene Fossils from the Baynunah Formation, U.A.E. (pp. xxx). Cham: Springer. 
Polissar, P. J., and D'Andrea, W. J., 2014, Uncertainty in paleohydrologic reconstructions from molecular $\delta$ D values: Geochimica et Cosmochimica Acta, v. 129, p. 146-156.

Polissar, P. J., Rose, C., Uno, K. T., Phelps, S. R., and deMenocal, P., 2019, Synchronous rise of African C4 ecosystems 10 million years ago in the absence of aridification: Nature Geoscience, v. 12, no. 8, p. 657-660.

Popov, S. V., Rögl, F., Rozanov, A. Y., Steininger, F. F., Shcherba, I. G., and Kovac, M., 2004, Lithological-Paleogeographic maps of Paratethys-10 maps Late Eocene to Pliocene: Courier Forschungsinstitut Senckenberg, v. 250, p. 1-46.

Quade, J., Cerling, T. E., and Bowman, J. R., 1989, Development of Asian monsoon revealed by marked ecological shift during the latest Miocene in northern Pakistan: Nature (London), v. 342 , no. 6246 , p. $163-166$.

Quade, J., Eiler, J., Daeron, M., and Achyuthan, H., 2013, The clumped isotope geothermometer in soil and paleosol carbonate: Geochimica et Cosmochimica Acta, v. 105, p. 92-107.

Sanders, W. J. (this volume). Proboscidea from the Baynunah Formation. In F. Bibi, B. Kraatz, M. Beech, \& A. Hill (eds.) Sands of Time: Late Miocene Fossils from the Baynunah Formation, U.A.E. (pp. xxx). Cham: Springer.

Sankaran, M., Hanan, N. P., Scholes, R. J., Ratnam, J., Augustine, D. J., Cade, B. S., Gignoux, J., Higgins, S. I., Le Roux, X., Ludwig, F., Ardo, J., Banyikwa, F., Bronn, A., Bucini, G., Caylor, K. K., Coughenour, M. B., Diouf, A., Ekaya, W., Feral, C. J., February, E. C., Frost, P. G. H., Hiernaux, P., Hrabar, H., Metzger, K. L., Prins, H. H. T., Ringrose, S., Sea, W., Tews, J., Worden, J., and Zambatis, N., 2005, Determinants of woody cover in African savannas: Nature, v. 438, no. 7069, p. 846-849. 
Schuster, M. (this volume). Sedimentology and Stratigraphy of the Baynunah Formation. In F. Bibi, B. Kraatz, M. Beech, \& A. Hill (eds.) Sands of Time: Late Miocene Fossils from the Baynunah Formation, U.A.E. (pp. xxx). Cham: Springer.

Sharp, Z. D., Cerling, T. E., Cerling, T. E., Harris, J. M., and MacFadden, B. J., 1998, Fossil isotope records of seasonal climate and ecology; straight from the horse's mouth: Carbon isotopes, diets of North American equids, and the evolution of North American C4 grasslands: Geology, v. 26, no. 3, p. 219-222.

Suga, S., 1979, Comparative Histology of Progressive Mineralization Pattern of Developing Incisor Enamel of Rodents: Journal of Dental Research, v. 58, no. 2 suppl, p. 1025-1026.

Swart, P. K., Burns, S. J., and Leder, J. J., 1991, Fractionation of the stable isotopes of oxygen and carbon in carbon dioxide during the reaction of calcite with phosphoric acid as a function of temperature and technique: Chemical Geology: Isotope Geoscience section, v. 86, no. 2, p. 89-96.

Tang, H., Eronen, J. T., Micheels, A., and Fortelius, M., 2011, Regional climate model experiment to investigate the Asian monsoon in the Late Miocene: Climate of the Past.

Tejada-Lara, J. V., MacFadden, B. J., Bermudez, L., Rojas, G., Salas-Gismondi, R., and Flynn, J. J., 2018, Body mass predicts isotope enrichment in herbivorous mammals: Proc. R. Soc. B, v. 285 , no. 1881 , p. 20181020.

Tieszen, L. L., Senyimba, M. M., Imbamba, S. K., and Troughton, J. H., 1979, The distribution of $\mathrm{C} 3$ and $\mathrm{C} 4$ grasses and carbon isotope discrimination along an altitudinal and moisture gradient in Kenya: Oecologia, v. 37, no. 3, p. 337-350. 
Tipple, B., Meyers, S., and Pagani, M., 2010, Carbon isotope ratio of Cenozoic CO2: A comparative evaluation of available geochemical proxies: Paleoceanography, v. 25, no. 3, p. 11 .

Uno, K. T., Cerling, T. E., Harris, J. M., Kunimatsu, Y., Leakey, M. G., Nakatsukasa, M., and Nakaya, H., 2011, Late Miocene to Pliocene carbon isotope record of differential diet change among East African herbivores: Proceedings of the National Academy of Sciences, v. 108, no. 16, p. 6509-6514.

Uno, K. T., Polissar, P. J., Jackson, K. E., and deMenocal, P. B., 2016a, Neogene biomarker record of vegetation change in eastern Africa: Proceedings of the National Academy of Sciences of the United States of America, v. 113, no. 23, p. 6355-6363.

Uno, K. T., Polissar, P. J., Kahle, E., Feibel, C., Harmand, S., Roche, H., and deMenocal, P. B., 2016b, A Pleistocene palaeovegetation record from plant wax biomarkers from the Nachukui Formation, West Turkana, Kenya: Phil. Trans. R. Soc. B, v. 371, no. 1698, p. 10.

Whybrow, P. J., Friend, P., Ditchfield, P., and Bristow, C. S., 1999, Local stratigraphy of the Neogene outcrops of the coastal area:Western Region, Emiarate of Abu Dhabi, United Arab Emirates, in Whybrow, P. J., and Hill, A., eds., Fossil Vertebrates of Arabia: New Haven, Connecticut, Yale University Press,, p. 28-37.

Whybrow, P. J., and Hill, A., 1999, Fossil Vertebrates of Arabia: New Haven, Connecticut, Yale University Press, p. 523.

Young, H. J., and Young, T. P., 1983, Local Distribution of $\mathrm{C}_{3}$ and $\mathrm{C}_{4}$ Grasses in Sites of Overlap on Mount Kenya: Oecologia, v. 58, no. 3, p. 373-377. 
Zazzo, A., Bendrey, R., Vella, D., Moloney, A., Monahan, F., and Schmidt, O., 2012, A refined sampling strategy for intra-tooth stable isotope analysis of mammalian enamel: Geochimica et Cosmochimica Acta, p. 13.

Zhang, Z., Ramstein, G., Schuster, M., Li, C., Contoux, C., and Yan, Q., 2014, Aridification of the Sahara desert caused by Tethys Sea shrinkage during the Late Miocene: Nature, v. 513, no. 7518, p. 401-404.

Zhuang, G., Pagani, M., and Zhang, Y. G., 2017, Monsoonal upwelling in the western Arabian Sea since the middle Miocene: Geology, v. 45, no. 7, p. 655-658. 


\section{TABLES}

Table 18.1. Calculated $\delta 13 \mathrm{C}$ values (\%, VPDB) for plant waxes, paleosol carbonate, enamel, and formed in equilibrium with $\mathrm{C}_{3}$ and $\mathrm{C}_{4}$ vegetation. The atmospheric $\mathrm{CO} 2$ value is from the high resolution benthic foramanifera record in Tipple et al. (2010). Enrichement factors for $\mathrm{CO}_{2}$ plants and for diet-enamel are from Cerling and Harris (1999); for n-alkanes, from Collister et al (1994); and for pedogenic carbonates, from Cerling (1984).

\begin{tabular}{|c|c|c|c|c|c|c|c|c|c|c|}
\hline & $\begin{array}{c}\delta^{13} \mathrm{C} \\
\text { atmos. }\end{array}$ & $\begin{array}{c}\varepsilon \mathrm{CO}_{2^{-}} \\
\mathrm{C}_{3} \text { plant }\end{array}$ & $\begin{array}{l}\delta^{13} \mathrm{C} \\
\text { plant }\end{array}$ & $\begin{array}{l}\delta^{13} \mathrm{C} \\
\text { plant }\end{array}$ & $\begin{array}{l}\varepsilon \mathrm{CO}_{2^{-}} \\
\mathrm{C}_{4} \text { plant }\end{array}$ & $\begin{array}{l}\delta^{13} \mathrm{C} \\
\text { plant }\end{array}$ & $\begin{array}{l}\text { Eplant- } \\
\text { proxy }\end{array}$ & $\delta^{13} \mathbf{C}$ & $\delta^{13} \mathbf{C}$ & $\delta^{13} \mathbf{C}$ \\
\hline substrate & $\mathrm{CO}_{2}$ & & avg. $\mathrm{C}_{3}$ & $\max . \mathrm{C}_{3}$ & & $\mathrm{C}_{4}$ & & avg. C3 & $\underset{\mathbf{C 3}}{\max }$ & $\operatorname{avg} C_{4}$ \\
\hline$n$-alkanes & -6.3 & $\begin{array}{r}19 . \\
6\end{array}$ & -25.4 & -22.6 & 4.7 & -10.9 & -8.0 & -33.1 & -30.3 & -18.8 \\
\hline fossil enamel & -6.3 & $\begin{array}{r}19 . \\
6\end{array}$ & -25.4 & -22.6 & 4.7 & -10.9 & +14.1 & -11.4 & -8.6 & 3.2 \\
\hline $\begin{array}{l}\text { pedeogenic } \\
\text { carbonate }\end{array}$ & -6.3 & $\begin{array}{r}19 . \\
6\end{array}$ & -25.4 & -22.6 & 4.7 & -10.9 & +14 & -11.4 & -8.7 & 3.1 \\
\hline
\end{tabular}

Table 18.2. n-Alkane sample information, concentration data, and CPI and ACL values.

\begin{tabular}{|c|c|c|c|c|c|c|c|c|c|c|c|c|c|c|c|c|}
\hline \multirow[b]{2}{*}{ Lab ID } & \multirow[b]{2}{*}{ Sample ID1 } & \multirow[b]{2}{*}{$\begin{array}{r}\text { Sampl } \\
\text { e ID2 }\end{array}$} & \multirow[b]{2}{*}{ Site } & \multirow[b]{2}{*}{ Lithology } & \multirow{2}{*}{$\begin{array}{r}\text { sampl } \\
\mathrm{e} \\
\text { mass } \\
(\mathrm{g})\end{array}$} & \multirow[b]{2}{*}{$\begin{array}{r}\text { CP } \\
\text { I }\end{array}$} & \multirow[b]{2}{*}{$\begin{array}{r}\mathbf{A C} \\
\mathbf{L}\end{array}$} & \multirow[b]{2}{*}{$\begin{array}{r}\text { nC2 } \\
7\end{array}$} & \multirow[b]{2}{*}{$\begin{array}{r}\mathrm{nC2} \\
8\end{array}$} & \multicolumn{7}{|c|}{$n$-alkane concentration (ng/g sediment) } \\
\hline & & & & & & & & & & $\begin{array}{r}\mathrm{nC2} \\
9\end{array}$ & $\begin{array}{r}\mathrm{nC3} \\
\mathbf{0}\end{array}$ & $\begin{array}{r}\mathrm{nC3} \\
1\end{array}$ & $\begin{array}{r}\mathrm{nC} 3 \\
2\end{array}$ & $\begin{array}{r}\mathrm{nC3} \\
\mathbf{3}\end{array}$ & $\begin{array}{r}\mathrm{nC3} \\
4\end{array}$ & $\begin{array}{r}\mathrm{nC3} \\
5\end{array}$ \\
\hline KU369_F1 & $\begin{array}{r}\text { AD14.H5.111 } \\
B\end{array}$ & $\begin{array}{l}\text { Hamr } \\
\text { a } 5.1\end{array}$ & $\begin{array}{l}\mathrm{HM} \\
\mathrm{R} 5\end{array}$ & $\begin{array}{r}\text { green clayey } \\
\text { silt }\end{array}$ & 118.8 & 3.1 & $\begin{array}{r}30 . \\
1\end{array}$ & 50.7 & 24.2 & 50.4 & 20.2 & 64.6 & 11.2 & 37.2 & 3.7 & 10.4 \\
\hline KU370_F1 & $\begin{array}{r}\text { AD14.H5.109 } \\
B\end{array}$ & $\begin{array}{l}\text { Hamr } \\
\text { a } 5.2\end{array}$ & $\begin{array}{l}\mathrm{HM} \\
\mathrm{R} 5\end{array}$ & $\begin{array}{r}\text { brown } \\
\text { clayey silt }\end{array}$ & 131.3 & 6.7 & $\begin{array}{r}30 . \\
3\end{array}$ & 4.9 & 1.9 & 8.7 & 1.6 & 12.6 & 0.9 & 6.3 & 0.2 & 0.6 \\
\hline KU375_F1 & $\begin{array}{r}5 \mathrm{H} 42 \text { Ilaria } \\
\# 3\end{array}$ & $\begin{array}{l}\text { Hamr } \\
\text { a } 5.3\end{array}$ & $\begin{array}{l}\mathrm{HM} \\
\mathrm{R} 5\end{array}$ & $\begin{array}{r}\text { green clayey } \\
\text { silt }\end{array}$ & 103.2 & 3.3 & $\begin{array}{r}29 . \\
6\end{array}$ & 4.7 & 1.9 & 4.3 & 1.2 & 4.2 & 0.7 & 1.8 & 0.2 & 0.4 \\
\hline KU371_F1 & $\begin{array}{r}\text { AD14.KH.107 } \\
B\end{array}$ & $\begin{array}{r}\text { Kihal } \\
107\end{array}$ & $\begin{array}{r}\mathrm{KIH} \\
2\end{array}$ & $\begin{array}{r}\text { green clayey } \\
\text { silt }\end{array}$ & 124.3 & 3.3 & $\begin{array}{r}29 . \\
7\end{array}$ & 4.7 & 1.9 & 4.0 & 1.2 & 4.2 & 0.6 & 2.0 & 0.2 & 0.6 \\
\hline KU372_F1 & $\begin{array}{r}\text { AD14.KH.108 } \\
B\end{array}$ & $\begin{array}{r}\text { Kihal } \\
108\end{array}$ & $\begin{array}{r}\mathrm{KIH} \\
2\end{array}$ & $\begin{array}{r}\text { green clayey } \\
\text { silt }\end{array}$ & 118.5 & 4.4 & $\begin{array}{r}29 . \\
6\end{array}$ & 4.9 & 1.8 & 5.2 & 1.1 & 5.4 & 0.5 & 2.1 & 0.1 & 0.2 \\
\hline KU373_F1 & $\begin{array}{r}\mathrm{AD} 14 . \mathrm{M} 1.101 \\
\mathrm{~B}\end{array}$ & $\begin{array}{r}\text { Mleisa } \\
1\end{array}$ & $\begin{array}{r}\text { MLS } \\
1\end{array}$ & $\begin{array}{r}\text { trackwaylay } \\
\text { er silt }\end{array}$ & 126.2 & 3.6 & $\begin{array}{r}28 . \\
8\end{array}$ & 4.3 & 1.2 & 2.7 & 0.6 & 1.8 & 0.1 & 0.6 & 0.1 & 0.2 \\
\hline KU374_F1 & $\begin{array}{r}\text { AD14.RU.11 } \\
2 B\end{array}$ & $\begin{array}{r}\text { Ruwai } \\
\text { s }\end{array}$ & $\begin{array}{l}\text { RU } \\
\text { W } \\
\text { SE }\end{array}$ & $\begin{array}{r}\text { brown silty } \\
\text { clay }\end{array}$ & 111.2 & 5.2 & $\begin{array}{r}30 . \\
5\end{array}$ & 2.5 & 1.0 & 3.2 & 0.7 & 4.6 & 0.4 & 2.9 & 0.3 & 0.7 \\
\hline & & & & & & & & & $-\mathbf{a}$ & $0 i$ & id & once & rati & (ng & sedi & lent) \\
\hline
\end{tabular}




\begin{tabular}{|c|c|c|c|c|c|c|c|c|c|c|c|c|c|c|c|c|}
\hline & & & & & & & & $\begin{array}{r}\mathrm{nC2} \\
6\end{array}$ & $\begin{array}{r}\mathrm{nC2} \\
7\end{array}$ & $\begin{array}{r}\mathrm{nC2} \\
8\end{array}$ & $\begin{array}{r}\mathrm{nC2} \\
9\end{array}$ & $\begin{array}{r}\mathrm{nC3} \\
0\end{array}$ & $\begin{array}{r}\mathrm{nC3} \\
1\end{array}$ & $\begin{array}{r}\mathrm{nC3} \\
2\end{array}$ & $\begin{array}{r}\mathrm{nC3} \\
3\end{array}$ & $\begin{array}{r}\mathrm{nC3} \\
4\end{array}$ \\
\hline $\begin{array}{r}\text { KU369_F3AMe } \\
\text { F3 }\end{array}$ & $\begin{array}{r}\text { AD14.H5.111 } \\
B\end{array}$ & $\begin{array}{r}\text { Hamr } \\
\text { a } 5.1\end{array}$ & $\begin{array}{l}\mathrm{HM} \\
\mathrm{R} 5\end{array}$ & $\begin{array}{r}\text { green clayey } \\
\text { silt }\end{array}$ & 118.8 & 2.2 & $\begin{array}{r}27 . \\
6\end{array}$ & $\begin{array}{r}227 . \\
8\end{array}$ & $\begin{array}{r}112 . \\
1\end{array}$ & $\begin{array}{r}190 . \\
1\end{array}$ & 45.4 & 60.9 & 17.3 & 24.9 & 4.1 & 6.1 \\
\hline $\begin{array}{r}\text { KU370_F3AMe } \\
\text { F3 }\end{array}$ & $\begin{array}{r}\text { AD14.H5.109 } \\
\text { B }\end{array}$ & $\begin{array}{r}\text { Hamr } \\
\text { a } 5.2\end{array}$ & $\begin{array}{l}\mathrm{HM} \\
\mathrm{R} 5\end{array}$ & $\begin{array}{r}\text { brown } \\
\text { clayey silt }\end{array}$ & 131.3 & 2.6 & $\begin{array}{r}27 . \\
9\end{array}$ & 17.4 & 8.2 & 19.5 & 5.4 & 9.0 & 1.8 & 3.1 & 0.2 & 0.3 \\
\hline $\begin{array}{r}\text { KU375_F3AMe } \\
\text { F3 }\end{array}$ & $\begin{array}{r}5 \mathrm{H} 42 \text { Ilaria } \\
\# 3\end{array}$ & $\begin{array}{r}\text { Hamr } \\
\text { a } 5.3\end{array}$ & $\begin{array}{l}\mathrm{HM} \\
\mathrm{R} 5\end{array}$ & $\begin{array}{r}\text { green clayey } \\
\text { silt }\end{array}$ & 103.2 & 2.6 & $\begin{array}{r}27 . \\
6\end{array}$ & $\begin{array}{r}223 . \\
3\end{array}$ & 95.5 & $\begin{array}{r}203 . \\
9\end{array}$ & 39.0 & 66.0 & 15.1 & 21.7 & 3.6 & 5.1 \\
\hline $\begin{array}{r}\text { KU371_F3AMe } \\
\text { F3 }\end{array}$ & $\begin{array}{r}\text { AD14.KH.107 } \\
\text { B }\end{array}$ & $\begin{array}{r}\text { Kihal } \\
107\end{array}$ & $\begin{array}{r}\mathrm{KIH} \\
2\end{array}$ & $\begin{array}{r}\text { green clayey } \\
\text { silt }\end{array}$ & 124.3 & 2.4 & $\begin{array}{r}28 . \\
0\end{array}$ & 5.8 & 3.6 & 8.2 & 1.8 & 2.8 & 0.7 & 1.1 & 0.1 & 0.2 \\
\hline $\begin{array}{r}\text { KU372_F3AMe } \\
\text { F3 }\end{array}$ & $\begin{array}{r}\text { AD14.KH.108 } \\
\text { B }\end{array}$ & $\begin{array}{r}\text { Kihal } \\
108\end{array}$ & $\begin{array}{r}\mathrm{KIH} \\
2\end{array}$ & $\begin{array}{r}\text { green clayey } \\
\text { silt }\end{array}$ & 118.5 & 2.5 & $\begin{array}{r}27 . \\
5\end{array}$ & 6.9 & 3.6 & 7.8 & 1.3 & 1.6 & 0.4 & 0.4 & 0.1 & 0.1 \\
\hline $\begin{array}{r}\text { KU373_F3AMe } \\
\text { F3 }\end{array}$ & $\begin{array}{r}\text { AD14.M1.101 } \\
\text { B }\end{array}$ & $\begin{array}{r}\text { Mleisa } \\
1\end{array}$ & $\begin{array}{r}\text { MLS } \\
1\end{array}$ & $\begin{array}{r}\text { trackwaylay } \\
\text { er silt }\end{array}$ & 126.2 & 2.5 & $\begin{array}{r}27 . \\
0\end{array}$ & 5.7 & 2.0 & 3.1 & 0.5 & 0.6 & 0.2 & 0.1 & 0.0 & 0.0 \\
\hline $\begin{array}{r}\text { KU374_F3AMe } \\
\text { F3 }\end{array}$ & $\begin{array}{r}\text { AD14.RU.11 } \\
2 B\end{array}$ & $\begin{array}{r}\text { Ruwai } \\
\mathrm{s}\end{array}$ & $\begin{array}{l}\text { RU } \\
\text { W } \\
\text { SE }\end{array}$ & $\begin{array}{r}\text { brown silty } \\
\text { clay }\end{array}$ & 111.2 & 2.6 & $\begin{array}{r}27 . \\
2\end{array}$ & 2.2 & 0.8 & 1.4 & 0.3 & 0.4 & 0.1 & 0.1 & 0.0 & 0.0 \\
\hline
\end{tabular}

Table 18.3. Carbon isotope data (\%o, VPDB) for odd-chain n-alkanes (C27 to C35) and evenchain fatty acids (C26 to $\mathrm{C} 34$ ). Percent $\mathrm{C} 4$ vegetation is calculated from the $n$-C31alkane where uncertainty, given as $1 \sigma$ accounts for $\mathrm{C}_{3}$ and $\mathrm{C}_{4}$ endmember variability and analytical uncertainty.

\begin{tabular}{|c|c|c|c|c|c|c|c|c|c|c|c|c|}
\hline \multirow[b]{2}{*}{ Lab ID } & \multirow[b]{2}{*}{ Sample ID1 } & \multirow[b]{2}{*}{$\begin{array}{c}\text { Sample } \\
\text { ID2 }\end{array}$} & \multirow[b]{2}{*}{ Site } & \multicolumn{5}{|c|}{$n$-alkane $\delta^{13} \mathbf{C}$} & \multirow[b]{2}{*}{$\% \mathrm{C4}$} & \multirow[b]{2}{*}{ $\pm \% \mathrm{C} 4$} & \multirow{2}{*}{$\begin{array}{c}\text { (WGS } \\
\text { 84) } \\
\text { lat } \\
\text { (north) }\end{array}$} & \multirow[b]{2}{*}{$\begin{array}{l}\text { long } \\
\text { (east) }\end{array}$} \\
\hline & & & & $\mathrm{C} 27$ & C29 & C31 & $\mathbf{C 3 3}$ & C35 & & & & \\
\hline KU369_F1 & AD14.H5.111B & $\begin{array}{r}\text { Hamra } \\
5.1\end{array}$ & HMR 5 & 27.4 & $26 . \overline{5}$ & $25 . \overline{-}$ & -25.2 & -23.5 & 52 & 13 & 24.10309 & 52.52832 \\
\hline KU370_F1 & AD14.H5.109B & $\begin{array}{r}\text { Hamra } \\
5.2\end{array}$ & HMR 5 & 26.7 & 27.0 & 28.0 & -26.9 & -25.5 & 36 & 15 & 24.103 & 52.528 \\
\hline KU375_F1 & 5H42 IIaria \#3 & $\begin{array}{r}\text { Hamra } \\
5.3\end{array}$ & HMR 5 & $28.0^{-}$ & $27 . \overline{3}$ & $27 . \overline{-}$ & -26.4 & -24.7 & 41 & 14 & 24.103 & 52.528 \\
\hline KU371_F1 & AD14.KH.107B & $\begin{array}{r}\text { Kihal } \\
107\end{array}$ & KIH 2 & 25.1 & 26.0 & 25.7 & -25.3 & -23.7 & 52 & 13 & 24.11847 & 53.02075 \\
\hline KU372_F1 & AD14.KH.108B & $\begin{array}{r}\text { Kihal } \\
108\end{array}$ & KIH 2 & 26.0 & 26.3 & 26.9 & -26.3 & -25.4 & 43 & 13 & 24.11900 & 53.02004 \\
\hline KU373_F1 & AD14.M1.101B & $\begin{array}{r}\text { Mleisa } \\
1\end{array}$ & MLS 1 & $22.0^{-}$ & $23.0^{-}$ & $22 . \overline{6}$ & -22.8 & -23.1 & 73 & 12 & 23.94812 & 53.06154 \\
\hline KU374_F1 & AD14.RU.112B & Ruwais & $\begin{array}{l}\text { RUW } \\
\text { SE }\end{array}$ & 27.2 & 28.6 & 29.2 & -28.1 & -26.4 & 27 & 16 & 24.07529 & 52.78897 \\
\hline & & & $\min$ & 28.0 & 28.6 & 29.2 & -28.1 & -26.4 & 27 & & & \\
\hline & & & $\max$ & $22.0^{-}$ & $23.0^{-}$ & $22 . \overline{6}$ & -22.8 & -23.1 & 73 & & & \\
\hline & & & mean & & - & - & -25.8 & -24.6 & 46 & & & \\
\hline
\end{tabular}




\begin{tabular}{|c|c|c|c|c|c|c|c|c|c|c|c|c|}
\hline & & & & 26.1 & 26.4 & 26.5 & & & & & & \\
\hline & & & stdev & 2.0 & 1.7 & 2.1 & 1.7 & 1.2 & 15 & & & \\
\hline & & & median & 26.7 & 26.5 & 26.9 & -26.3 & -24.7 & 43 & & & \\
\hline & & & & \multicolumn{5}{|c|}{$n$-alkanoic acid $\delta^{13} \mathrm{C}$} & & & & \\
\hline Lab ID & Sample ID1 & $\begin{array}{c}\text { Sample } \\
\text { ID2 }\end{array}$ & Site & $\mathrm{C26}$ & $\mathrm{C} 28$ & $\mathbf{C 3 0}$ & C32 & C34 & & & $\begin{array}{c}\text { lat } \\
\text { (north) }\end{array}$ & $\begin{array}{l}\text { long } \\
\text { (east) }\end{array}$ \\
\hline KU369_F3AMeF2 & AD14.H5.111B & $\begin{array}{r}\text { Hamra } \\
5.1\end{array}$ & HMR 5 & $29 . \overline{-}$ & 30.1 & 28.5 & -25.4 & -28.5 & -- & -- & 24.10309 & 52.52832 \\
\hline KU370_F3AMeF2 & AD14.H5.109B & $\begin{array}{r}\text { Hamra } \\
5.2 \\
\end{array}$ & HMR 5 & 28.5 & 29.8 & $28 . \overline{-}^{-}$ & -25.8 & -25.3 & -- & -- & 24.103 & 52.528 \\
\hline KU375_F3AMeF2 & 5H42 IIaria \#3 & $\begin{array}{r}\text { Hamra } \\
5.3\end{array}$ & HMR 5 & 28.5 & 30.6 & 28.9 & -27.7 & -28.9 & -- & -- & 24.103 & 52.528 \\
\hline KU371_F3AMeF2 & AD14.KH.107B & $\begin{array}{r}\text { Kihal } \\
107\end{array}$ & KIH 2 & 25.7 & 27.0 & $26 . \overline{-}$ & -24.7 & -24.8 & -- & -- & 24.11847 & 53.02075 \\
\hline KU372_F3AMeF2 & AD14.KH.108B & $\begin{array}{r}\text { Kihal } \\
108\end{array}$ & KIH 2 & $27 . \overline{-}$ & $28.8^{-}$ & $27 . \overline{1}$ & -24.3 & -24.1 & -- & -- & 24.11900 & 53.02004 \\
\hline KU373_F3AMeF2 & AD14.M1.101B & $\begin{array}{r}\text { Mleisa } \\
1\end{array}$ & MLS 1 & 21.9 & $23 . \overline{2}^{-}$ & 22.9 & -21.5 & -23.6 & -- & -- & 23.94812 & 53.06154 \\
\hline KU374_F3AMeF2 & AD14.RU.112B & Ruwais & $\begin{array}{l}\text { RUW } \\
\text { SE }\end{array}$ & $28.1^{-}$ & 29.1 & $28 . \overline{9}^{-}$ & -28.3 & -26.2 & -- & -- & 24.07529 & 52.78897 \\
\hline & & & $\min$ & $29 . \overline{-}$ & $30 . \overline{6}$ & 28.9 & -28.3 & -28.9 & & & & \\
\hline & & & $\max$ & $21 . \overline{-}$ & $23.2^{-}$ & $22 . \overline{9}$ & -21.5 & -23.6 & & & & \\
\hline & & & mean & 27.0 & $\begin{array}{r}- \\
28.4\end{array}$ & $27 . \overline{3}$ & -25.4 & -25.9 & & & & \\
\hline & & & stdev & 2.5 & 2.6 & 2.2 & 2.3 & 2.1 & & & & \\
\hline & & & median & 28.1 & 29.1 & $28 . \overline{-}$ & -25.4 & -25.3 & & & & \\
\hline
\end{tabular}

Table 18.4. Comparison of tooth enamel carbon and oxygen isotope data (\%o, VPDB) from treated and untreated samples. Treatment methods are described in the text.

\begin{tabular}{|c|c|c|c|c|c|c|}
\hline Sample ID & & $\delta^{13} \mathbf{C}$ & & & $\delta^{18} \mathbf{O}$ & \\
\hline & $\overline{\text { UNT }}$ & TRT & TRT-UNT & UNT & TRT & TRT-UNT \\
\hline AUH_1554-3 & -0.1 & -0.0 & & -3.6 & -2.6 & \\
\hline AUH_1554-6 & 0.2 & -0.0 & & -3.9 & -3.1 & \\
\hline AUH_1554-24 & -1.4 & -1.3 & & -2.0 & -1.0 & \\
\hline AUH_1554-27 & -2.3 & -2.0 & & -2.1 & -1.3 & \\
\hline AUH_1554-30 & -1.9 & -2.2 & & -2.9 & -1.9 & \\
\hline AUH_1554-48 & -0.8 & -0.6 & & -5.6 & -5.9 & \\
\hline
\end{tabular}




\begin{tabular}{|l|l|l|l|l|l|l|}
\hline AUH_1554-51 & -0.3 & -0.5 & & -5.7 & -6.0 & \\
\hline AUH_1554-54 & -0.6 & -0.6 & & -4.1 & -4.5 & \\
\hline AUH-1295-6 & -6.4 & -5.8 & & -3.7 & -4.0 & \\
\hline AUH-1295-9 & -6.6 & -6.4 & & -3.6 & -5.5 & \\
\hline AUH-1295-12 & -4.4 & -5.0 & & -2.2 & -4.6 & \\
\hline & & avg & & & & \\
\hline & & stdev & $\mathbf{0 . 3}$ & & & \\
\hline & & $\min$ & & & & \\
\hline & & $\max$ & & & & \\
\hline
\end{tabular}

Table 18.5. Tooth enamel carbon and oxygen isotope data for Baynunah large mammals (\%o,VPDB). Percent $\mathrm{C}_{4}$ diet is given along with uncertainty (1s) that accounts for $\mathrm{C}_{3}$ and $\mathrm{C}_{4}$ endmember variability and analytical uncertainty. Data in this table includes carbon and oxygen values from Kingston, 1999. The original oxygen isotope values from Kingston (1999) are also provided. [TYPESETTER - THIS TABLE IN LANDSCAPE ORIENTATION]

\begin{tabular}{|c|c|c|c|c|c|c|c|c|c|c|c|}
\hline $\begin{array}{l}\text { Speci- } \\
\text { men ID }\end{array}$ & $\begin{array}{l}\text { Other } \\
\text { ID }\end{array}$ & Order & Family & Taxon & $\begin{array}{c}\text { Ele- } \\
\text { ment }\end{array}$ & Site & $\% \mathrm{C} 4$ & $\pm \% \mathrm{C} 4$ & d13C & d18O & d180 Source \\
\hline $\begin{array}{l}\text { AUH } \\
266\end{array}$ & & $\begin{array}{l}\text { Artio- } \\
\text { dactyla }\end{array}$ & Bovidae & $\begin{array}{l}\text { Pachyportax } \\
\text { latidens }\end{array}$ & xlt. m2 & HMR 6 & 51 & 12 & -4.0 & -4.5 & $\begin{array}{ll}-- & \text { this } \\
& \text { study }\end{array}$ \\
\hline $\begin{array}{l}\text { AUH } \\
278\end{array}$ & & $\begin{array}{l}\text { Artio- } \\
\text { dactyla }\end{array}$ & Bovidae & $\begin{array}{l}\text { Pachyportax } \\
\text { latidens }\end{array}$ & $\begin{array}{l}\text { xlt. molar } \\
\text { frag. }\end{array}$ & rHMR 5 & 79 & 12 & 0.1 & -3.6 & $\begin{array}{c}-4.6 \text { Kingsto } \\
\mathrm{n}, 1999\end{array}$ \\
\hline AUH 2 & AD 628 & $\begin{array}{l}\text { Artio- } \\
\text { dactyla }\end{array}$ & Bovidae & $\begin{array}{l}\text { Tragoportax } \\
\text { cyrenaicus }\end{array}$ & $\begin{array}{l}\text { ffrag- } \\
\text { ment }\end{array}$ & SHU 1 & 36 & 14 & -6.1 & -1.0 & $\begin{array}{c}-2.0 \text { Kingsto } \\
\mathrm{n}, 1999\end{array}$ \\
\hline $\begin{array}{l}\text { AUH } \\
239\end{array}$ & & $\begin{array}{l}\text { Artio- } \\
\text { dactyla }\end{array}$ & Bovidae & $\begin{array}{l}\text { Tragoportax } \\
\text { cyrenaicus }\end{array}$ & $\begin{array}{l}\text { rmolar } \\
\text { frag. }\end{array}$ & THM 1 & 7 & 19 & -10.4 & -1.6 & $\begin{array}{r}-2.6 \text { Kingsto } \\
\mathrm{n}, 1999\end{array}$ \\
\hline AD635 & & $\begin{array}{l}\text { Artio- } \\
\text { dactyla }\end{array}$ & Bovidae & $\begin{array}{l}\text { Gen et sp } \\
\text { indet. }\end{array}$ & $\begin{array}{l}\text { molar } \\
\text { frag. }\end{array}$ & THM 1 & 33 & 15 & -6.6 & -5.0 & $\begin{array}{c}-6.0 \text { Kingsto } \\
\mathrm{n}, 1999\end{array}$ \\
\hline $\begin{array}{l}\text { AUH } \\
1124\end{array}$ & & $\begin{array}{l}\text { Artio- } \\
\text { dactyla }\end{array}$ & $\begin{array}{l}\text { Giraffi- } \\
\text { dae }\end{array}$ & $\begin{array}{l}\text { Gen et sp } \\
\text { indet. }\end{array}$ & $\begin{array}{l}\text { molar } \\
\text { frag. }\end{array}$ & $\begin{array}{l}\text { RDB 1- } \\
1\end{array}$ & 73 & 12 & -0.8 & 6.6 & $\begin{array}{ll}-- & \text { this } \\
& \text { study }\end{array}$ \\
\hline $\begin{array}{l}\text { AUH } \\
204 \text { avg }\end{array}$ & & $\begin{array}{l}\text { Artio- } \\
\text { dactyla }\end{array}$ & $\begin{array}{l}\text { Giraffi- } \\
\text { dae }\end{array}$ & $\begin{array}{l}\text { ?Bramath- } \\
\text { erium sp. }\end{array}$ & $\begin{array}{l}\text { rt. } M \\
\text { frag. }\end{array}$ & RDB 2 & 79 & 12 & 0.2 & 7.0 & $\begin{array}{ll}-- & \text { this } \\
& \text { study }\end{array}$ \\
\hline $\begin{array}{l}\text { AUH } \\
206 \text { avg }\end{array}$ & 1165 & $\begin{array}{l}\text { Artio- } \\
\text { dactyla }\end{array}$ & $\begin{array}{l}\text { Giraffi- } \\
\text { dae }\end{array}$ & $\begin{array}{l}\text { ?Bramath- } \\
\text { erium sp. }\end{array}$ & $\begin{array}{l}\text { unworn } \\
M \text { frag. }\end{array}$ & RDB 2 & 68 & 12 & -1.5 & 3.4 & $\begin{array}{l}0.2 \text { this } \\
\text { study; } \\
\text { Kingsto } \\
\text { n, } 1999\end{array}$ \\
\hline $\begin{array}{l}\text { AUH } \\
211\end{array}$ & $\begin{array}{l}\mathrm{AD} \\
627 \mathrm{a}\end{array}$ & $\begin{array}{l}\text { Artio- } \\
\text { dactyla }\end{array}$ & $\begin{array}{l}\text { Giraffi- } \\
\text { dae }\end{array}$ & $\begin{array}{l}\text { cf. Samoth- } \\
\text { erium or } \\
\text { Palaeotragus } \\
\text { aff. ger- } \\
\text { maini }\end{array}$ & $\begin{array}{l}\text { lt. M } \\
\text { frag } \\
\text { s }\end{array}$ & RDB 2 & 15 & 18 & -9.2 & 5.3 & $\begin{array}{r}\text { 4.3Kingsto } \\
\text { n, } 1999\end{array}$ \\
\hline $\begin{array}{l}\text { AUH } \\
372\end{array}$ & $\mathrm{AD} 766$ & $\begin{array}{l}\text { Artio- } \\
\text { dactyla }\end{array}$ & $\begin{array}{l}\text { Giraffi- } \\
\text { dae }\end{array}$ & $\begin{array}{l}\text { ?Bramath- } \\
\text { erium sp. }\end{array}$ & lt. M & RDB 2 & 40 & 14 & -5.6 & -3.9 & $\begin{array}{r}-4.9 \text { Kingsto } \\
\text { n, } 1999\end{array}$ \\
\hline $\begin{array}{l}\text { AUH } \\
217\end{array}$ & AD 767 & $\begin{array}{l}\text { Artio- } \\
\text { dactyla }\end{array}$ & $\begin{array}{l}\text { Giraffi- } \\
\text { dae }\end{array}$ & $\begin{array}{l}\text { ?Bramath- } \\
\text { erium sp. }\end{array}$ & rt. dP4 & RDB 2 & 60 & 12 & -2.7 & 2.9 & $\begin{array}{r}\text { 1.9Kingsto } \\
\mathrm{n}, 1999\end{array}$ \\
\hline AUH & & $\begin{array}{l}\text { Artio- } \\
\text { dactyla }\end{array}$ & $\begin{array}{l}\text { Hip- } \\
\text { popotam }\end{array}$ & $\begin{array}{l}\text { Ar- } \\
\text { hchaeopota- }\end{array}$ & canine & SHU 1 & 78 & 12 & 0.0 & -6.3 & $\begin{array}{l}\text { this } \\
\text { study }\end{array}$ \\
\hline
\end{tabular}


idae mus cf.

qeshta

\begin{tabular}{|c|c|c|c|c|c|c|c|c|c|c|c|}
\hline AUH 31 & $\begin{array}{l}\text { Artio- } \\
\text { dactyla }\end{array}$ & $\begin{array}{l}\text { Hip- } \\
\text { popotan } \\
\text { idae }\end{array}$ & $\begin{array}{l}\text { Gen et sp } \\
\text { nindet. }\end{array}$ & molar & SHU 1 & 77 & 12 & -0.2 & -5.5 & -- & $\begin{array}{l}\text { this } \\
\text { study }\end{array}$ \\
\hline AUH 60 & $\begin{array}{l}\text { Artio- } \\
\text { dactyla }\end{array}$ & $\begin{array}{l}\text { Hip- } \\
\text { popotan } \\
\text { idae }\end{array}$ & $\begin{array}{l}\text { Gen et } \mathrm{sp} \\
\text { mindet. }\end{array}$ & $\begin{array}{l}\text { premo- } \\
\text { lar }\end{array}$ & SHU 1 & 73 & 12 & -0.8 & -8.1 & -- & $\begin{array}{l}\text { this } \\
\text { study }\end{array}$ \\
\hline AUH 92 & $\begin{array}{l}\text { Artio- } \\
\text { dactyla }\end{array}$ & $\begin{array}{l}\text { Hip- } \\
\text { popotan } \\
\text { idae }\end{array}$ & $\begin{array}{l}\text { Gen et sp } \\
\text { nindet. }\end{array}$ & $\begin{array}{l}\text { premo- } \\
\text { lar }\end{array}$ & SHU 1 & 68 & 12 & -1.5 & -4.9 & -- & $\begin{array}{l}\text { this } \\
\text { study }\end{array}$ \\
\hline $\begin{array}{l}\text { AUH } \\
110\end{array}$ & $\begin{array}{l}\text { Artio- } \\
\text { dactyla }\end{array}$ & $\begin{array}{l}\text { Hip- } \\
\text { popotan } \\
\text { idae }\end{array}$ & $\begin{array}{l}\text { Ar- } \\
\text { nchaeopota- } \\
\text { mus cf. } \\
\text { qeshta }\end{array}$ & 1t. $\mathrm{m} 2$ & SHU 1 & 77 & 12 & -0.2 & -6.1 & -- & $\begin{array}{l}\text { this } \\
\text { study }\end{array}$ \\
\hline $\begin{array}{l}\text { AUH } \\
359\end{array}$ & $\begin{array}{l}\text { Artio- } \\
\text { dactyla }\end{array}$ & $\begin{array}{l}\text { Hip- } \\
\text { popotan } \\
\text { idae }\end{array}$ & $\begin{array}{l}\text { Ar- } \\
\text { nchaeopota- } \\
\text { mus qeshta }\end{array}$ & $\begin{array}{l}\text { canine } \\
\text { frag. }\end{array}$ & HAR 1 & 80 & 12 & 0.3 & -5.2 & -- & $\begin{array}{l}\text { this } \\
\text { study }\end{array}$ \\
\hline $\begin{array}{l}\text { AUH } \\
421\end{array}$ & $\begin{array}{l}\text { Artio- } \\
\text { dactyla }\end{array}$ & $\begin{array}{l}\text { Hip- } \\
\text { popotan } \\
\text { idae }\end{array}$ & $\begin{array}{l}\text { Ar- } \\
\text { nchaeopota- } \\
\text { mus qeshta }\end{array}$ & $\mathrm{P} 4$ & JDH 4 & 70 & 12 & -1.2 & -7.5 & -- & $\begin{array}{l}\text { this } \\
\text { study }\end{array}$ \\
\hline $\mathrm{AD} 630$ & $\begin{array}{l}\text { Artio- } \\
\text { dactyla }\end{array}$ & $\begin{array}{l}\text { Hip- } \\
\text { popotan } \\
\text { idae }\end{array}$ & $\begin{array}{l}\text { Gen et sp } \\
\text { nindet. }\end{array}$ & $\begin{array}{l}\text { molar } \\
\text { frag. }\end{array}$ & $\mathrm{JDH}$ & 76 & 12 & -0.3 & -9.5 & & $\begin{array}{c}.5 \text { Kingsto } \\
\mathrm{n}, 1999\end{array}$ \\
\hline AD 631 & $\begin{array}{l}\text { Artio- } \\
\text { dactyla }\end{array}$ & $\begin{array}{l}\text { Hip- } \\
\text { popotan } \\
\text { idae }\end{array}$ & $\begin{array}{l}\text { Gen et } \mathrm{sp} \\
\text { mindet. }\end{array}$ & $\begin{array}{l}\text { molar } \\
\text { frag. }\end{array}$ & SHU 1 & 67 & 12 & -1.7 & -7.4 & & $\begin{array}{r}\text { 3.4Kingsto } \\
\text { n, } 1999\end{array}$ \\
\hline $\begin{array}{l}\text { AUH } \\
1728\end{array}$ & $\begin{array}{l}\text { Artio- } \\
\text { dactyla }\end{array}$ & $\begin{array}{l}\text { Hip- } \\
\text { popotan } \\
\text { idae }\end{array}$ & $\begin{array}{l}\text { Gen et sp } \\
\text { nindet. }\end{array}$ & $\begin{array}{l}\text { upper } \\
\text { premo- } \\
\text { lar }\end{array}$ & RUW C & 67 & 12 & -1.7 & -8.6 & -- & $\begin{array}{l}\text { this } \\
\text { study }\end{array}$ \\
\hline $\begin{array}{l}\text { AUH } \\
619 a\end{array}$ & $\begin{array}{l}\text { BMNH- Artio- } \\
\text { M49464 dactyla }\end{array}$ & $\begin{array}{l}\text { Hip- } \\
\text { popotan } \\
\text { idae }\end{array}$ & $\begin{array}{l}\text { Ar- } \\
\text { nchaeopota- } \\
\text { mus qeshta }\end{array}$ & $\begin{array}{l}\text { frag- } \\
\text { ment }\end{array}$ & JBR 2 & 40 & 14 & -5.5 & -7.5 & & $\begin{array}{r}\text { 3.5Kingsto } \\
\mathrm{n}, 1999\end{array}$ \\
\hline $\begin{array}{l}\text { AUH } \\
329\end{array}$ & $\begin{array}{l}\text { Artio- } \\
\text { dactyla }\end{array}$ & Suidae & $\begin{array}{l}\text { Nyanza- } \\
\text { choerus } \\
\text { syticus }\end{array}$ & lt $\mathrm{m} 3$ & HMR 1 & 2 & 20 & -11.1 & -2.3 & -- & $\begin{array}{l}\text { this } \\
\text { study }\end{array}$ \\
\hline $\begin{array}{l}\text { AUH } \\
784\end{array}$ & $\begin{array}{l}\text { Artio- } \\
\text { dactyla }\end{array}$ & Suidae & $\begin{array}{l}\text { Nyanza- } \\
\text { choerus } \\
\text { syticus }\end{array}$ & $\begin{array}{l}\text { molar } \\
\text { crown } \\
\text { frag. }\end{array}$ & RDB 2 & 6 & 20 & -10.6 & -5.0 & -- & $\begin{array}{l}\text { this } \\
\text { study }\end{array}$ \\
\hline AUH 55 & $\begin{array}{l}\text { Artio- } \\
\text { dactyla }\end{array}$ & Suidae & $\begin{array}{l}\text { Propotomo- } \\
\text { choerus } \\
\text { hysudricus }\end{array}$ & - lt M3 & SHU 1 & 12 & 18 & -9.7 & -4.7 & -- & $\begin{array}{l}\text { this } \\
\text { study }\end{array}$ \\
\hline $\begin{array}{l}\text { AUH } \\
1295\end{array}$ & $\begin{array}{l}\text { Perisso- } \\
\text { dactyla }\end{array}$ & - Equidae & $\begin{array}{l}\text { Gen et sp } \\
\text { indet. }\end{array}$ & $\begin{array}{l}\text { rt P4 or } \\
\text { M1 }\end{array}$ & HMR 5 & 70 & 12 & -1.1 & -4.2 & -- & $\begin{array}{l}\text { this } \\
\text { study }\end{array}$ \\
\hline $\begin{array}{l}\text { AUH } \\
1465\end{array}$ & $\begin{array}{l}\text { Perisso- } \\
\text { dactyla }\end{array}$ & - Equidae & $\begin{array}{l}\text { Gen et sp } \\
\text { indet. }\end{array}$ & $\begin{array}{l}\text { lower } \\
\text { tooth }\end{array}$ & SHU 2 & 50 & 13 & -4.1 & -2.9 & -- & $\begin{array}{l}\text { this } \\
\text { study }\end{array}$ \\
\hline $\begin{array}{l}\text { AUH } \\
1535\end{array}$ & $\begin{array}{l}\text { Perisso- } \\
\text { dactyla }\end{array}$ & - Equidae & $\begin{array}{l}\text { "Hipparion' } \\
\text { abudhabi- } \\
\text { ense }\end{array}$ & $\begin{array}{l}\text { "lt m1 or } \\
\mathrm{m} 2\end{array}$ & GAA 2 & 66 & 12 & -1.7 & -6.3 & -- & $\begin{array}{l}\text { this } \\
\text { study }\end{array}$ \\
\hline $\begin{array}{l}\text { AUH } \\
1554\end{array}$ & $\begin{array}{l}\text { Perisso- } \\
\text { dactyla }\end{array}$ & Equidae & $\begin{array}{l}\text { Gen et sp } \\
\text { indet. }\end{array}$ & $\begin{array}{l}\text { rt. } \mathrm{m} 1 \\
\text { or } \mathrm{m} 2\end{array}$ & GAA 1 & 72 & 12 & -0.8 & -4.7 & -- & $\begin{array}{l}\text { this } \\
\text { study }\end{array}$ \\
\hline $\begin{array}{l}\text { AUH } \\
1566\end{array}$ & $\begin{array}{l}\text { Perisso- } \\
\text { dactyla }\end{array}$ & - Equidae & $\begin{array}{l}\text { e Gen et } \mathrm{sp} \\
\text { indet. }\end{array}$ & $\begin{array}{l}\text { rt. M1 } \\
\text { or M2 }\end{array}$ & GAA 3 & 49 & 13 & -4.3 & -6.0 & -- & $\begin{array}{l}\text { this } \\
\text { study }\end{array}$ \\
\hline $\begin{array}{l}\text { AUH } \\
1712\end{array}$ & $\begin{array}{l}\text { Perisso- } \\
\text { dactyla }\end{array}$ & - Equidae & $\begin{array}{l}\text { "Hipparion' } \\
\text { abudhabi- }\end{array}$ & $\begin{array}{l}\text { "p4 or } \\
\text { m1 }\end{array}$ & JBR & 47 & 13 & -4.5 & -3.2 & -- & $\begin{array}{l}\text { this } \\
\text { study }\end{array}$ \\
\hline
\end{tabular}




\begin{tabular}{|c|c|c|c|c|c|c|c|c|c|c|}
\hline $\begin{array}{l}\text { AUH } \\
609\end{array}$ & $\mathrm{AD} 621$ & $\begin{array}{l}\text { Perisso- Equidae } \\
\text { dactyla }\end{array}$ & $\begin{array}{l}\text { "Hipparion' } \\
\text { sp. }\end{array}$ & $\begin{array}{l}\text { frag- } \\
\text { ment }\end{array}$ & JDH 3 & 65 & 12 & -1.9 & -5.1 & $\begin{array}{r}-6.1 \text { Kingsto } \\
\text { n, } 1999\end{array}$ \\
\hline AUH 4 & $\begin{array}{l}6 \mathrm{AD} \\
622 \mathrm{a}\end{array}$ & $\begin{array}{l}\text { Perisso- Equidae } \\
\text { dactyla }\end{array}$ & $\begin{array}{l}\text { "Hipparion' } \\
\text { sp. }\end{array}$ & $\begin{array}{l}\text { " frag- } \\
\text { ment }\end{array}$ & HMR 5 & 53 & 12 & -3.6 & -5.7 & $\begin{array}{r}-6.6 \text { Kingsto } \\
\mathrm{n}, 1999\end{array}$ \\
\hline AUH 2 & $3 \mathrm{AD} 623$ & $\begin{array}{l}\text { Perisso- Equidae } \\
\text { dactyla }\end{array}$ & $\begin{array}{l}\text { "Hipparion } \\
\text { abudhabi- } \\
\text { ense }\end{array}$ & $\begin{array}{l}\text { "lt molar } \\
\text { frag. }\end{array}$ & SHU 1 & 37 & 14 & -6.1 & -4.9 & $\begin{array}{r}-5.9 \text { Kingsto } \\
\mathrm{n}, 1999\end{array}$ \\
\hline AD 633 & & $\begin{array}{l}\text { Perisso- Equidae } \\
\text { dactyla }\end{array}$ & $\begin{array}{l}\text { "Hipparion' } \\
\text { sp. }\end{array}$ & $\begin{array}{l}\text { " molar } \\
\text { frag. }\end{array}$ & $\mathrm{KIH}$ & 82 & 12 & 0.5 & -4.1 & $\begin{array}{r}-5.1 \text { Kingsto } \\
\mathrm{n}, 1999\end{array}$ \\
\hline AD 634 & & $\begin{array}{l}\text { Perisso- Equidae } \\
\text { dactyla }\end{array}$ & $\begin{array}{l}\text { "Hipparion' } \\
\text { sp. }\end{array}$ & $\begin{array}{l}\text { " molar } \\
\text { frag. }\end{array}$ & HMR 5 & 40 & 14 & -5.6 & -3.0 & $\begin{array}{r}-4.0 \text { Kingsto } \\
\text { n, } 1999\end{array}$ \\
\hline $\begin{array}{l}\text { AUH } \\
208\end{array}$ & AD 750 & $\begin{array}{l}\text { Perisso- Equidae } \\
\text { dactyla }\end{array}$ & $\begin{array}{l}\text { "Hipparion' } \\
\text { sp. }\end{array}$ & $\begin{array}{l}\text { "lower } \\
\text { molar } \\
\text { frag. }\end{array}$ & RDB 2 & 24 & 16 & -7.8 & -1.7 & $\begin{array}{r}-2.7 \text { Kingsto } \\
\mathrm{n}, 1999\end{array}$ \\
\hline $\begin{array}{l}\text { AUH } \\
231 \mathrm{a}\end{array}$ & $\mathrm{AD} 751$ & $\begin{array}{l}\text { Perisso- Equidae } \\
\text { dactyla }\end{array}$ & $\begin{array}{l}\text { "Hipparion } \\
\text { abudhabi- } \\
\text { ense }\end{array}$ & "P3 or P4 & 4HMR 5 & 72 & 12 & -1.0 & -7.3 & $\begin{array}{r}-8.3 \text { Kingsto } \\
\text { n, } 1999\end{array}$ \\
\hline $\begin{array}{l}\text { AUH } \\
260\end{array}$ & $\mathrm{AD} 752$ & $\begin{array}{l}\text { Perisso- Equidae } \\
\text { dactyla }\end{array}$ & $\begin{array}{l}\text { "Hipparion } \\
\text { abudhabi- } \\
\text { ense }\end{array}$ & $\begin{array}{l}\text { "upper? } \\
\text { molar }\end{array}$ & KIH 1 & 62 & 12 & -2.4 & -5.7 & $\begin{array}{r}-6.7 \text { Kingsto } \\
\text { n, } 1999\end{array}$ \\
\hline $\begin{array}{l}\text { AUH } \\
212\end{array}$ & AD 753 & $\begin{array}{l}\text { Perisso- Equidae } \\
\text { dactyla }\end{array}$ & $\begin{array}{l}\text { "Hipparion' } \\
\text { sp. }\end{array}$ & $\begin{array}{l}=\mathrm{m} 1 \text { or } \\
\mathrm{m} 2\end{array}$ & RDB 2 & 75 & 12 & -0.4 & 0.5 & $\begin{array}{r}-0.5 \text { Kingsto } \\
\mathrm{n}, 1999\end{array}$ \\
\hline $\begin{array}{l}\text { AUH } \\
178\end{array}$ & AD 754 & $\begin{array}{l}\text { Perisso- Equidae } \\
\text { dactyla }\end{array}$ & $\begin{array}{l}\text { "Hipparion' } \\
\text { sp. }\end{array}$ & $\begin{array}{l}\text { " rt. P3 or } \\
\text { P4 }\end{array}$ & JDH 5 & 55 & 12 & -3.3 & -2.8 & $\begin{array}{r}-3.8 \text { Kingsto } \\
\mathrm{n}, 1999\end{array}$ \\
\hline $\begin{array}{l}\text { AUH } \\
205\end{array}$ & AD 757 & $\begin{array}{l}\text { Perisso- Equidae } \\
\text { dactyla }\end{array}$ & $\begin{array}{l}\text { "Hipparion' } \\
\text { sp. }\end{array}$ & $\begin{array}{l}\text { " rt. P3 or } \\
\text { P4 }\end{array}$ & RDB 2 & 28 & 15 & -7.4 & 0.3 & $\begin{array}{r}-0.6 \text { Kingsto } \\
\mathrm{n}, 1999\end{array}$ \\
\hline $\begin{array}{l}\text { AUH } \\
115\end{array}$ & AD 758 & $\begin{array}{l}\text { Perisso- Equidae } \\
\text { dactyla }\end{array}$ & $\begin{array}{l}\text { "Hipparion } \\
\text { abudhabi- } \\
\text { ense }\end{array}$ & $\begin{array}{l}\text { M1 or } \\
\text { M2 }\end{array}$ & SHU 1 & 76 & 12 & -0.3 & -5.8 & $\begin{array}{r}-6.8 \text { Kingsto } \\
\text { n, } 1999\end{array}$ \\
\hline AD 759 & M50664 & $\begin{array}{l}\text { Perisso- Equidae } \\
\text { dactyla }\end{array}$ & $\begin{array}{l}\text { "Hipparion' } \\
\text { sp. }\end{array}$ & " P2 & JBR 2 & 78 & 12 & 0.0 & -5.8 & $\begin{array}{r}-6.8 \text { Kingsto } \\
\mathrm{n}, 1999\end{array}$ \\
\hline $\mathrm{AD} 760$ & M50663 & $\begin{array}{l}\text { Perisso- Equidae } \\
\text { dactyla }\end{array}$ & $\begin{array}{l}\text { "Hipparion } \\
\text { abudhabi- } \\
\text { ense }\end{array}$ & $\begin{array}{l}\text { "rt lower } \\
\text { molar }\end{array}$ & JBR 2 & 84 & 12 & 0.9 & -2.1 & $\begin{array}{r}-3.1 \text { Kingsto } \\
\text { n, } 1999\end{array}$ \\
\hline $\begin{array}{l}\text { AUH } \\
174\end{array}$ & $\mathrm{AD} 761$ & $\begin{array}{l}\text { Perisso- Equidae } \\
\text { dactyla }\end{array}$ & $\begin{array}{l}\text { "Hipparion } \\
\text { abudhabi- } \\
\text { ense }\end{array}$ & $\begin{array}{l}\text { "rt lower } \\
\text { premo- } \\
\text { lar }\end{array}$ & HMR 1 & 73 & 12 & -0.7 & -5.4 & $\begin{array}{r}-6.4 \text { Kingsto } \\
\text { n, } 1999\end{array}$ \\
\hline AUH 72 & $2 \mathrm{AD} 763$ & $\begin{array}{l}\text { Perisso- Equidae } \\
\text { dactyla }\end{array}$ & $\begin{array}{l}\text { "Hipparion } \\
\text { abudhabi- } \\
\text { ense }\end{array}$ & $\begin{array}{l}\text { "lower } \\
\text { molar }\end{array}$ & SHU 1 & 54 & 12 & -3.5 & -6.0 & $\begin{array}{r}-7.0 \text { Kingsto } \\
\mathrm{n}, 1999\end{array}$ \\
\hline $\begin{array}{l}\text { AUH } \\
265\end{array}$ & AD 764 & $\begin{array}{l}\text { Perisso- Equidae } \\
\text { dactyla }\end{array}$ & $\begin{array}{l}\text { "Hipparion' } \\
\text { sp. }\end{array}$ & $\begin{array}{l}\text { " rt lower } \\
\text { premo- } \\
\text { lar }\end{array}$ & JDH 4 & 69 & 12 & -1.4 & -3.7 & $\begin{array}{r}-4.7 \text { Kingsto } \\
\mathrm{n}, 1999\end{array}$ \\
\hline $\begin{array}{l}\text { AUH } \\
677\end{array}$ & AD 765 & $\begin{array}{l}\text { Perisso- Equidae } \\
\text { dactyla }\end{array}$ & $\begin{array}{l}\text { Gen et } \mathrm{sp} \\
\text { indet. }\end{array}$ & $\begin{array}{l}\text { rt lower } \\
\text { molar }\end{array}$ & SHU 4 & 35 & 14 & -6.3 & -6.3 & $\begin{array}{r}-7.3 \text { Kingsto } \\
\mathrm{n}, 1999\end{array}$ \\
\hline $\begin{array}{l}\text { AUH } \\
162\end{array}$ & & $\begin{array}{l}\text { Perisso- Rhinoce } \\
\text { dactyla rotidae }\end{array}$ & $\begin{array}{l}\text { Gen et } \mathrm{sp} \\
\text { indet. }\end{array}$ & $\begin{array}{l}\text { frag- } \\
\text { ment }\end{array}$ & SHU 1 & 9 & 19 & -10.2 & -5.5 & $\begin{array}{ll}-- & \text { this } \\
& \text { study }\end{array}$ \\
\hline AUH 4 & & $\begin{array}{l}\text { Perisso- Rhinoce } \\
\text { dactyla rotidae }\end{array}$ & $\begin{array}{l}\text { Gen et sp } \\
\text { indet. }\end{array}$ & $\begin{array}{l}\text { frag- } \\
\text { ment }\end{array}$ & SHU 1 & 7 & 19 & -10.4 & -5.3 & $\begin{array}{ll}-- & \text { this } \\
& \text { study }\end{array}$ \\
\hline $\begin{array}{l}\text { AUH } \\
159\end{array}$ & & $\begin{array}{l}\text { Pro- Deinoth } \\
\text { boscide eriidae } \\
\text { a }\end{array}$ & $\begin{array}{l}\text { aff. } \\
\text { Deinotheriu } \\
\text { m bozasi }\end{array}$ & $\begin{array}{l}\text { molar } \\
u \text { frag. }\end{array}$ & SHU 1 & 0 & 22 & -12.4 & -1.7 & $\begin{array}{ll}-- & \text { this } \\
& \text { study }\end{array}$ \\
\hline AUH 2 & & $\begin{array}{l}\text { Pro- Deinoth } \\
\text { boscide eriidae } \\
\text { a }\end{array}$ & $\begin{array}{l}\text { aff. } \\
\text { Deinotheriu } \\
\text { m bozasi }\end{array}$ & $\begin{array}{l}\text { molar } \\
u \text { frag. }\end{array}$ & SHU 1 & 0 & 23 & -13.2 & -4.6 & $\begin{array}{ll}-- & \text { this } \\
& \text { study }\end{array}$ \\
\hline IUH 10 & & Pro- & Stegatetra- & molar & HMR 2 & 63 & 12 & -2.2 & -4.5 & this \\
\hline
\end{tabular}




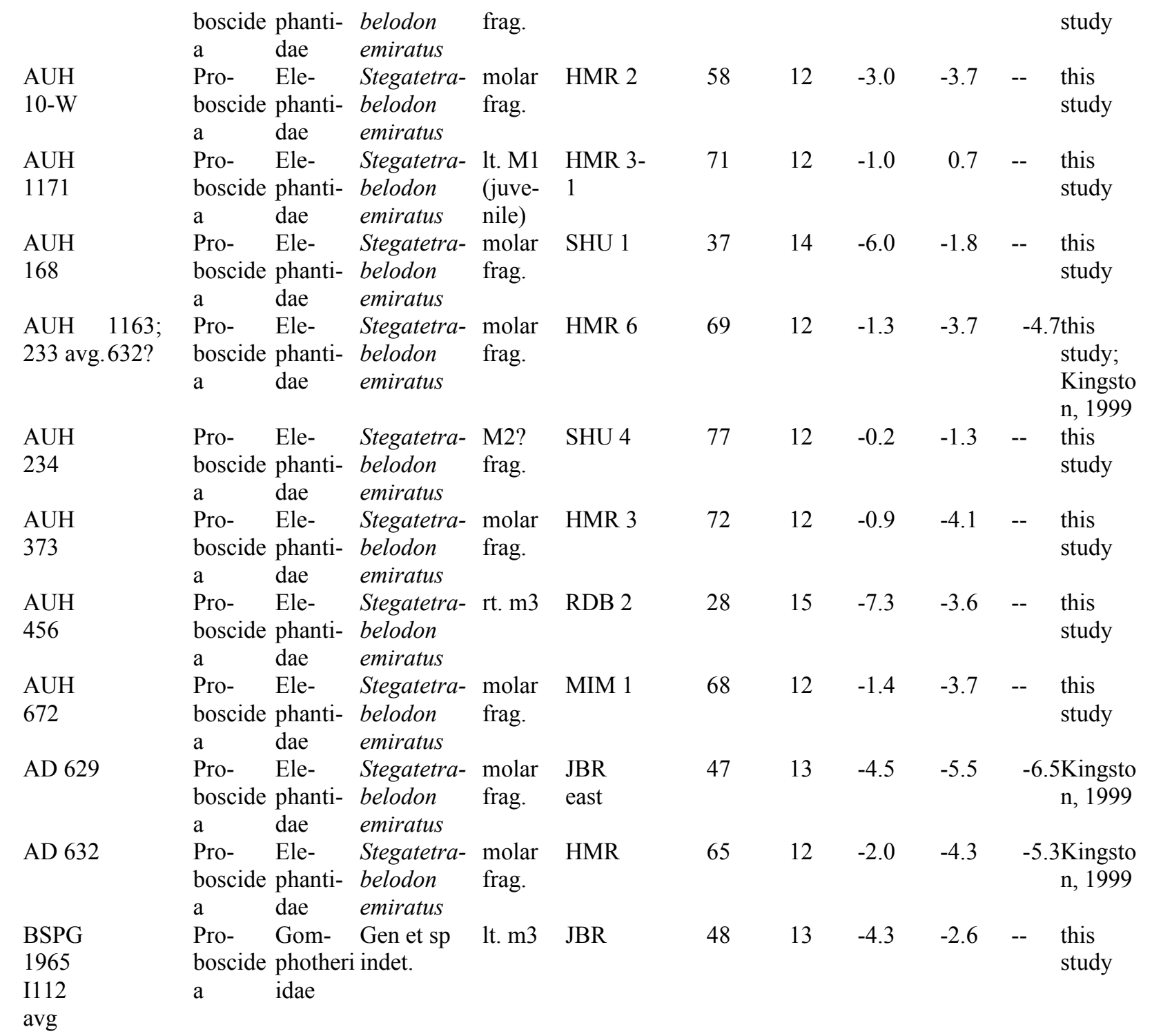

Table 18.6. Intratooth stable isotope (\%, VPDB) and \%C4 $( \pm 1 \sigma)$ data for Equidae molar profiles. Smoothed data (3 pt., weighted 0.25/0.50/0.25) and inverse model results (estimated input signal) are given with $2 \sigma$ uncertainty. Sample locations are given as distance from the cervix. Summary statistics are provided for each intratooth profile. Estimated input signal was calculated using Matlab code modified from "mSolve_1.m" published by Passey et al. (2005).

\begin{tabular}{|c|c|c|c|c|c|c|c|c|c|}
\hline \multirow[b]{2}{*}{ Sample ID } & \multicolumn{2}{|c|}{$\begin{array}{l}\text { measured } \\
\text { (smoothed) }\end{array}$} & \multicolumn{4}{|c|}{ estimated input signal (model results) } & \multirow[b]{2}{*}{$\% \mathrm{C} 4$} & \multirow[b]{2}{*}{$\begin{array}{l} \pm 1 \sigma \\
\% \mathrm{C} 4\end{array}$} & \multirow{2}{*}{$\begin{array}{c}\text { distance } \\
(\mathrm{mm})\end{array}$} \\
\hline & $\delta^{13} \mathbf{C}$ & $\delta^{18} \mathbf{O}$ & $\delta^{13} \mathbf{C}$ & $\begin{array}{l} \pm 2 \sigma \\
\delta^{13} \mathrm{C}\end{array}$ & $\delta^{18} \mathbf{O}$ & $\begin{array}{l} \pm 2 \sigma \\
\delta^{18} O\end{array}$ & & & \\
\hline
\end{tabular}




\begin{tabular}{|c|c|c|c|c|c|c|c|c|c|}
\hline AUH-1554-3 & -0.0 & -2.6 & -1.2 & 0.6 & -4.1 & 1.2 & 70 & 12 & 3 \\
\hline AUH-1554-6 & -0.0 & -3.1 & -0.2 & 0.6 & -4.7 & 1.2 & 76 & 12 & 6 \\
\hline AUH-1554-9 & 0.4 & -2.2 & 1.4 & 0.8 & -3.8 & 0.8 & 87 & 12 & 9 \\
\hline AUH-1554-12 & 0.5 & -2.1 & 2.5 & 1.0 & -4.2 & 0.7 & 95 & 13 & 12 \\
\hline AUH-1554-15 & 0.4 & -1.8 & 2.7 & 1.0 & -3.5 & 0.8 & 97 & 13 & 15 \\
\hline AUH-1554-18 & -0.4 & -1.4 & 1.0 & 1.0 & -2.8 & 0.8 & 85 & 12 & 18 \\
\hline AUH-1554-21 & -1.3 & -1.5 & 0.2 & 0.6 & -1.2 & 1.3 & 79 & 12 & 21 \\
\hline AUH-1554-24 & -1.3 & -1.0 & -0.3 & 0.9 & 0.6 & 1.3 & 76 & 12 & 24 \\
\hline AUH-1554-27 & -2.0 & -1.3 & -1.7 & 0.8 & 0.5 & 1.4 & 66 & 12 & 27 \\
\hline AUH-1554-30 & -2.2 & -1.9 & -2.1 & 0.7 & -0.1 & 1.4 & 64 & 12 & 30 \\
\hline AUH-1554-33 & -2.0 & -2.9 & -1.6 & 0.6 & -1.1 & 1.2 & 67 & 12 & 33 \\
\hline AUH-1554-36 & -1.7 & -3.7 & -2.0 & 0.8 & -1.2 & 0.9 & 64 & 12 & 36 \\
\hline AUH-1554-39 & -1.8 & -4.0 & -2.8 & 0.6 & -1.4 & 1.1 & 59 & 12 & 39 \\
\hline AUH-1554-42 & -1.4 & -4.7 & -2.2 & 0.8 & -2.9 & 0.9 & 63 & 12 & 42 \\
\hline AUH-1554-45 & -0.8 & -5.3 & -1.7 & 0.5 & -4.6 & 1.2 & 66 & 12 & 45 \\
\hline AUH-1554-48 & -0.6 & -5.9 & -1.6 & 0.5 & -6.0 & 1.4 & 67 & 12 & 48 \\
\hline AUH-1554-51 & -0.5 & -6.0 & -1.8 & 0.8 & -5.3 & 1.9 & 66 & 12 & 51 \\
\hline AUH-1554-54 & -0.6 & -4.5 & -1.7 & 0.7 & -4.4 & 1.2 & 67 & 12 & 54 \\
\hline $\begin{array}{l}\text { AUH-1554- } \\
\text { CEM }\end{array}$ & -3.4 & -4.1 & -- & -- & -- & -- & -- & -- & -- \\
\hline $\min$ & -2.2 & -6.0 & -2.8 & -- & -6.0 & -- & 59 & & \\
\hline $\max$ & 0.5 & -1.0 & 2.7 & -- & 0.6 & -- & 97 & & \\
\hline range & 2.7 & 5.0 & 5.5 & -- & 6.6 & -- & 38 & & \\
\hline mean & -0.8 & -3.1 & -0.7 & -- & -2.8 & -- & 73 & & \\
\hline AUH-1295-3 & -2.8 & 0.2 & -4.7 & 0.8 & 4.4 & 2.8 & 46 & 13 & 3 \\
\hline AUH-1295-6 & -2.8 & -2.1 & -4.4 & 0.9 & -1.1 & 1.8 & 48 & 13 & 6 \\
\hline AUH-1295-9 & -2.1 & -2.9 & -3.6 & 0.8 & -1.5 & 1.3 & 53 & 12 & 9 \\
\hline AUH-1295-12 & -1.6 & -3.4 & -2.9 & 0.8 & -4.0 & 1.9 & 58 & 12 & 12 \\
\hline AUH-1295-15 & -0.9 & -4.4 & -2.1 & 0.6 & -6.2 & 1.3 & 64 & 12 & 15 \\
\hline AUH-1295-18 & -0.6 & -3.9 & -1.4 & 0.6 & -4.6 & 1.4 & 68 & 12 & 18 \\
\hline AUH-1295-21 & -0.3 & -3.1 & -0.6 & 0.7 & -3.4 & 1.1 & 74 & 12 & 21 \\
\hline AUH-1295-24 & -0.0 & -2.5 & 0.2 & 0.9 & -3.6 & 0.8 & 79 & 12 & 24 \\
\hline AUH-1295-27 & -0.1 & -2.5 & 0.3 & 1.0 & -3.5 & 1.7 & 80 & 12 & 27 \\
\hline AUH-1295-30 & -0.3 & -1.8 & -1.0 & 1.5 & -1.5 & 2.8 & 71 & 12 & 30 \\
\hline AUH-1295-33 & -1.5 & -0.9 & -1.3 & 0.8 & -1.7 & 2.0 & 69 & 12 & 33 \\
\hline $\begin{array}{l}\text { AUH-1295- } \\
\text { CEM }\end{array}$ & -3.5 & -3.8 & -- & -- & -- & -- & -- & -- & -- \\
\hline $\min$ & -2.8 & -4.4 & -4.7 & -- & -6.2 & -- & 46 & & \\
\hline $\max$ & -0.0 & 0.2 & 0.3 & -- & 4.4 & -- & 80 & & \\
\hline range & 2.8 & 4.6 & 4.9 & -- & 10.6 & -- & 34 & & \\
\hline mean & -1.2 & -2.5 & -2.0 & -- & -2.4 & -- & 65 & & \\
\hline
\end{tabular}




\begin{tabular}{|c|c|c|c|c|c|c|c|c|c|}
\hline AUH-1566-3 & -6.8 & -0.8 & -5.9 & 1.0 & 2.1 & 2.2 & 38 & 14 & 3 \\
\hline AUH-1566-6 & -6.8 & -0.8 & -7.2 & 1.1 & 2.8 & 2.2 & 29 & 15 & 6 \\
\hline AUH-1566-9 & -7.1 & -2.1 & -8.2 & 0.9 & 1.7 & 1.9 & 22 & 16 & 9 \\
\hline AUH-1566-12 & -6.5 & -3.0 & -7.5 & 1.0 & 0.4 & 1.8 & 27 & 16 & 12 \\
\hline AUH-1566-15 & -5.5 & -4.5 & -7.5 & 0.8 & -2.4 & 1.9 & 27 & 16 & 15 \\
\hline AUH-1566-18 & -5.4 & -5.9 & -7.8 & 0.9 & -3.3 & 0.9 & 25 & 16 & 18 \\
\hline AUH-1566-21 & -4.6 & -5.6 & -6.9 & 0.9 & -4.1 & 1.7 & 31 & 15 & 21 \\
\hline AUH-1566-24 & -3.9 & -6.8 & -6.1 & 0.9 & -6.8 & 1.3 & 37 & 14 & 24 \\
\hline AUH-1566-27 & -3.2 & -6.8 & -5.4 & 0.6 & -6.4 & 1.2 & 41 & 14 & 27 \\
\hline AUH-1566-30 & -2.8 & -6.1 & -4.0 & 0.8 & -6.0 & 1.2 & 51 & 12 & 30 \\
\hline AUH-1566-33 & -2.0 & -5.6 & -2.8 & 0.7 & -6.8 & 1.0 & 59 & 12 & 33 \\
\hline AUH-1566-36 & -2.2 & -5.4 & -2.2 & 0.7 & -6.7 & 1.2 & 63 & 12 & 36 \\
\hline AUH-1566-39 & -2.1 & -4.5 & -1.9 & 0.6 & -6.2 & 0.9 & 65 & 12 & 39 \\
\hline AUH-1566-42 & -2.5 & -4.6 & -2.3 & 1.3 & -7.1 & 1.6 & 62 & 12 & 42 \\
\hline AUH-1566-45 & -2.8 & -4.5 & -2.2 & 1.2 & -6.5 & 1.3 & 63 & 12 & 45 \\
\hline $\begin{array}{l}\text { AUH-1566- } \\
\text { CEM }\end{array}$ & -5.6 & -4.2 & -- & -- & -- & -- & -- & -- & -- \\
\hline $\min$ & -7.1 & -6.8 & -8.2 & -- & -7.1 & -- & 22 & & \\
\hline $\max$ & -2.0 & -0.8 & -1.9 & -- & 2.8 & -- & 65 & & \\
\hline range & 5.0 & 6.1 & 6.3 & -- & 9.8 & -- & 43 & & \\
\hline mean & -4.3 & -4.5 & -5.2 & -- & -3.7 & -- & 43 & & \\
\hline AUH-1535-6 & -3.6 & -2.8 & -4.4 & 1.1 & -1.3 & 1.0 & 48 & 13 & 6 \\
\hline AUH-1535-9 & -3.3 & -2.9 & -4.8 & 1.2 & -1.0 & 1.4 & 46 & 13 & 9 \\
\hline AUH-1535-12 & -2.9 & -3.4 & -4.5 & 1.0 & -1.0 & 1.4 & 47 & 13 & 12 \\
\hline AUH-1535-15 & -2.3 & -4.0 & -4.4 & 0.8 & -2.5 & 1.3 & 48 & 13 & 15 \\
\hline AUH-1535-18 & -2.0 & -5.3 & -4.1 & 1.0 & -4.1 & 0.8 & 50 & 13 & 18 \\
\hline AUH-1535-21 & -1.3 & -5.8 & -3.3 & 0.8 & -5.0 & 0.8 & 55 & 12 & 21 \\
\hline AUH-1535-24 & -0.7 & -6.2 & -2.0 & 1.2 & -5.5 & 0.7 & 64 & 12 & 24 \\
\hline AUH-1535-27 & 0.1 & -6.2 & -0.1 & 1.6 & -5.3 & 1.0 & 78 & 12 & 27 \\
\hline AUH-1535-30 & 0.7 & -6.0 & 0.1 & 1.5 & -5.1 & 1.0 & 78 & 12 & 30 \\
\hline $\begin{array}{l}\text { AUH-1535- } \\
\text { CEM }\end{array}$ & -3.4 & -4.4 & -- & -- & -- & -- & -- & -- & -- \\
\hline $\min$ & -3.6 & -6.2 & -4.8 & -- & -5.5 & -- & 46 & & \\
\hline $\max$ & 0.7 & -2.8 & 0.1 & -- & -1.0 & -- & 78 & & \\
\hline range & 4.3 & 3.4 & 4.8 & -- & 4.5 & -- & 33 & & \\
\hline mean & -1.7 & -4.7 & -3.0 & -- & -3.4 & -- & 57 & & \\
\hline AUH-1465-3 & -5.1 & -0.4 & -7.8 & 1.5 & -0.6 & 1.0 & 25 & 16 & 3 \\
\hline AUH-1465-6 & -4.0 & -1.2 & -5.9 & 0.9 & -2.1 & 1.0 & 38 & 14 & 6 \\
\hline AUH-1465-9 & -3.6 & -1.3 & -4.2 & 1.2 & -2.6 & 1.4 & 49 & 13 & 9 \\
\hline
\end{tabular}




\begin{tabular}{|c|c|c|c|c|c|c|c|c|c|}
\hline AUH-1465-12 & -2.6 & -2.0 & -2.6 & 0.8 & -5.0 & 1.5 & 60 & 12 & 12 \\
\hline AUH-1465-15 & -3.0 & -2.5 & -3.3 & 0.7 & -3.7 & 1.8 & 56 & 12 & 15 \\
\hline AUH-1465-18 & -3.1 & -0.6 & -2.7 & 0.7 & 0.1 & 1.4 & 59 & 12 & 18 \\
\hline AUH-1465-21 & -3.1 & 0.2 & -1.8 & 0.9 & 1.0 & 1.2 & 66 & 12 & 21 \\
\hline AUH-1465-24 & -3.1 & 0.0 & -1.9 & 0.9 & 2.5 & 1.6 & 65 & 12 & 24 \\
\hline AUH-1465-27 & -3.8 & 0.4 & -3.0 & 0.8 & 3.0 & 1.8 & 58 & 12 & 27 \\
\hline AUH-1465-30 & -4.3 & -0.9 & -3.2 & 0.8 & -0.2 & 1.8 & 56 & 12 & 30 \\
\hline AUH-1465-33 & -4.8 & -2.4 & -3.7 & 0.8 & -3.3 & 1.7 & 53 & 12 & 33 \\
\hline AUH-1465-36 & -5.0 & -3.1 & -3.2 & 0.8 & -5.6 & 2.9 & 56 & 12 & 36 \\
\hline AUH-1465-39 & -4.8 & -3.9 & -5.0 & 1.5 & -3.2 & 3.2 & 44 & 13 & 39 \\
\hline AUH-1465-42 & -5.8 & -0.8 & -5.6 & 1.4 & 1.8 & 1.6 & 40 & 14 & 42 \\
\hline AUH-1465-45 & -4.7 & -1.3 & -3.8 & 0.8 & -0.1 & 1.1 & 52 & 12 & 45 \\
\hline $\min$ & -5.8 & -3.9 & -7.8 & -- & -5.6 & -- & 25 & & \\
\hline $\max$ & -2.6 & 0.4 & -1.8 & -- & 3.0 & -- & 66 & & \\
\hline range & 3.1 & 4.2 & 6.0 & -- & 8.6 & -- & 41 & & \\
\hline mean & -4.1 & -1.3 & -3.8 & -- & -1.2 & -- & 52 & & \\
\hline AUH-1712-3 & -4.7 & -3.4 & -3.5 & 0.7 & -3.5 & 1.7 & 54 & 12 & 3 \\
\hline AUH-1712-6 & -4.6 & -2.2 & -3.2 & 0.7 & 1.0 & 2.0 & 56 & 12 & 6 \\
\hline AUH-1712-9 & -4.8 & -1.0 & -4.2 & 0.9 & 1.7 & 1.6 & 49 & 13 & 9 \\
\hline AUH-1712-12 & -5.6 & -2.1 & -6.4 & 0.9 & -1.8 & 1.5 & 34 & 14 & 12 \\
\hline AUH-1712-15 & -6.1 & -3.4 & -7.0 & 1.0 & -2.5 & 0.8 & 30 & 15 & 15 \\
\hline AUH-1712-18 & -5.6 & -2.7 & -6.3 & 0.7 & -1.2 & 0.6 & 35 & 14 & 18 \\
\hline AUH-1712-21 & -5.0 & -2.7 & -5.7 & 0.6 & -2.8 & 1.3 & 39 & 14 & 21 \\
\hline AUH-1712-24 & -4.6 & -3.3 & -4.8 & 0.7 & -5.7 & 1.6 & 45 & 13 & 24 \\
\hline AUH-1712-27 & -4.0 & -3.9 & -4.1 & 0.6 & -6.6 & 1.7 & 50 & 13 & 27 \\
\hline AUH-1712-30 & -3.9 & -2.8 & -4.4 & 0.5 & -4.6 & 1.5 & 48 & 13 & 30 \\
\hline AUH-1712-33 & -4.2 & -1.7 & -5.2 & 0.6 & -3.3 & 1.5 & 43 & 13 & 33 \\
\hline AUH-1712-36 & -4.3 & -0.7 & -5.2 & 0.5 & -0.8 & 2.4 & 43 & 13 & 36 \\
\hline AUH-1712-39 & -4.0 & 1.1 & -4.6 & 0.6 & 0.2 & 1.6 & 46 & 13 & 39 \\
\hline AUH-1712-42 & -4.0 & -0.2 & -4.4 & 0.6 & -2.5 & 0.9 & 48 & 13 & 42 \\
\hline AUH-1712-45 & -4.1 & -0.6 & -3.6 & 0.9 & -1.6 & 1.3 & 53 & 12 & 45 \\
\hline AUH-1712-48 & -3.6 & 0.2 & -2.8 & 0.7 & -0.6 & 1.1 & 59 & 12 & 48 \\
\hline $\begin{array}{l}\text { AUH-1712- } \\
\text { CEM }\end{array}$ & -5.3 & -4.7 & -- & -- & -- & -- & -- & -- & -- \\
\hline $\min$ & -6.1 & -3.9 & -7.0 & -- & -6.6 & -- & 30 & & \\
\hline $\max$ & -3.6 & 1.1 & -2.8 & -- & 1.7 & -- & 59 & & \\
\hline range & 2.5 & 5.0 & 4.1 & -- & 8.3 & -- & 28 & & \\
\hline mean & -4.6 & -1.8 & -4.7 & -- & -2.2 & -- & 46 & & \\
\hline
\end{tabular}


Table 18.7. Modern $\delta 18 \mathrm{O}$ values for precipitation include measured values from the United Arab Emirates (UAE) and the GNIP station from Bahrain $(n=102 ; 2 \sigma)$ and modeled values for western Abu Dhabi based on the Online Isotopes in Precipitation Calculator (OIPC; 95\% CI).

\begin{tabular}{|l|c|r|}
\hline \multicolumn{1}{|c|}{ Precipitation Location } & \multicolumn{1}{c|}{$\delta^{18} \mathrm{O}$} & \multicolumn{1}{c|}{$\delta \mathrm{D}$} \\
\hline Bahrain Airport (GNIP Station) & $+0.5 \pm 5.6$ & $+12.4 \pm 35$ \\
\hline UAE (Rizk and Alhsharhan, 2003) & +0.8 & +12.4 \\
\hline OIPC (Bowen 2019) & $+0.1 \pm 0.4$ & $+12.4 \pm 17.3$ \\
\hline average & $+\mathbf{0 . 5}$ & $+\mathbf{1 2 . 4}$ \\
\hline
\end{tabular}

Table 18.8. Summary statistics of percent $\mathrm{C}_{4}$ vegetation and diet at different Baynunah Formation fossil sites. Median uncertainty in percent $\mathrm{C}_{4}$ calculations is $\pm 12 \%$.

\begin{tabular}{|c|c|c|c|c|}
\hline & & Percent C4 & & \\
\hline Site & diet & $n$-alkane & ped carb & \\
\hline \multirow[t]{4}{*}{ Hamra } & 2 & 36 & 16 & $\min$. \\
\hline & 79 & 52 & 63 & $\max$. \\
\hline & 65 & 41 & 37 & median \\
\hline & 13 & 3 & & $\mathrm{n}$ \\
\hline & & & & \\
\hline \multirow[t]{4}{*}{ Kihal } & 62 & 43 & 45 & min. \\
\hline & 82 & 52 & 62 & max. \\
\hline & 72 & 47 & 53 & median \\
\hline & 2 & 2 & & $\mathrm{n}$ \\
\hline & & & & \\
\hline \multirow[t]{4}{*}{$\begin{array}{r}\text { Jebel } \\
\text { Barakah }\end{array}$} & 40 & -- & 32 & min. \\
\hline & 84 & -- & 55 & $\max$. \\
\hline & 48 & -- & 45 & median \\
\hline & 6 & -- & & $\mathrm{n}$ \\
\hline & & & & \\
\hline \multirow{4}{*}{ Shuwaihat } & 0 & -- & -- & min. \\
\hline & 78 & -- & -- & max. \\
\hline & 50 & -- & 48 & median \\
\hline & 19 & -- & & $\mathrm{n}$ \\
\hline & & & & \\
\hline \multirow[t]{3}{*}{ Ruwais } & 67 & 27 & -- & \\
\hline & 1 & 1 & & $\mathrm{n}$ \\
\hline & & & & \\
\hline
\end{tabular}




\begin{tabular}{|r|r|r|l|l|}
\hline All data & 0 & 27 & 16 & min. \\
\hline & 84 & 73 & 63 & max. \\
\hline & 63 & 43 & 40 & median \\
\hline & 24 & 15 & 15 & $1 \sigma$ \\
\hline & 84 & 46 & 47 & range \\
\hline & 65 & 7 & 15 & n \\
\hline
\end{tabular}

Table 18.9. Fraction woody cover (fwc) data calculated from pedogenic carbonate $\delta^{13} \mathrm{C}$ values from Baynunah, Lothagam, and the Pakistani Siwaliks. Data from the latter two sites are restricted to 8 to $6 \mathrm{Ma}$ and all paleomagnetic based ages for the Siwaliks were updated to the timescale of Gradstein and Ogg (2012). Data are from Kingston (1999), Cerling et al. (2003a), Quade et al. (1989), and Behrensmeyer et al. (2007).

\begin{tabular}{|r|c|r|r|r|}
\hline & & \multicolumn{3}{|c|}{ Percent of data set by site } \\
\hline \multicolumn{1}{|c|}{$\boldsymbol{f w c}$} & Ecosystem type & Baynunah & Lothagam & Siwaliks \\
\hline$>0.4$ & $\begin{array}{c}\text { grassy woodland, bushland } \\
\text { or shrubland to forest }\end{array}$ & $26 \%$ & $24 \%$ & $73 \%$ \\
\hline 0.4 to 0.1 & woody grassland & $69 \%$ & $70 \%$ & $24 \%$ \\
\hline$>0.1$ & grassland & $5 \%$ & $6 \%$ & $3 \%$ \\
\hline
\end{tabular}


Fig 18.1

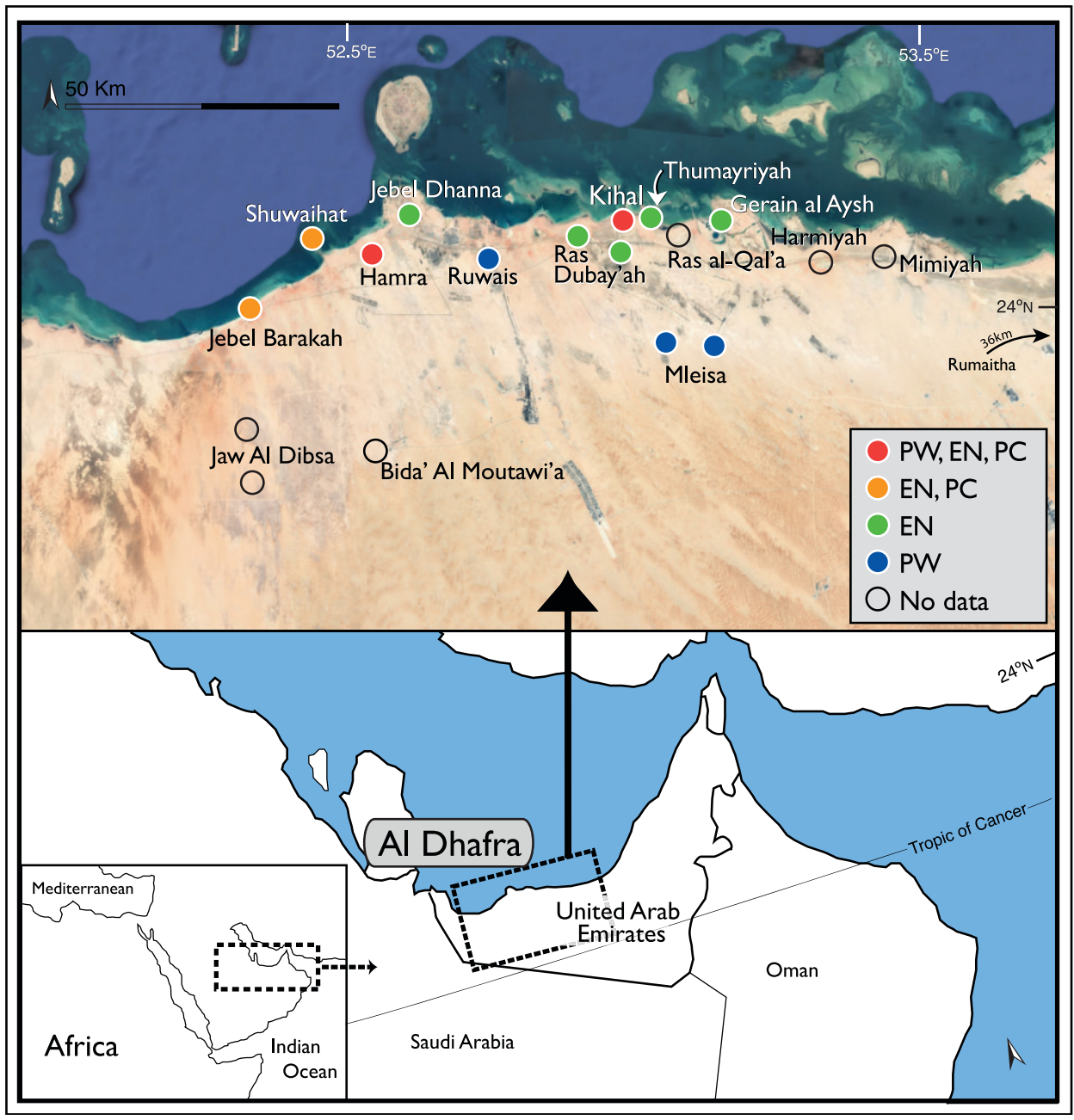


Fig 18.2

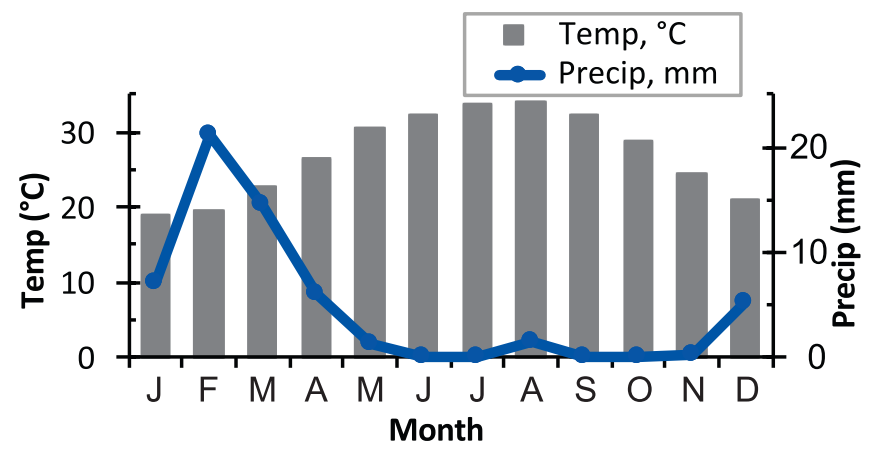


Fig 18.3
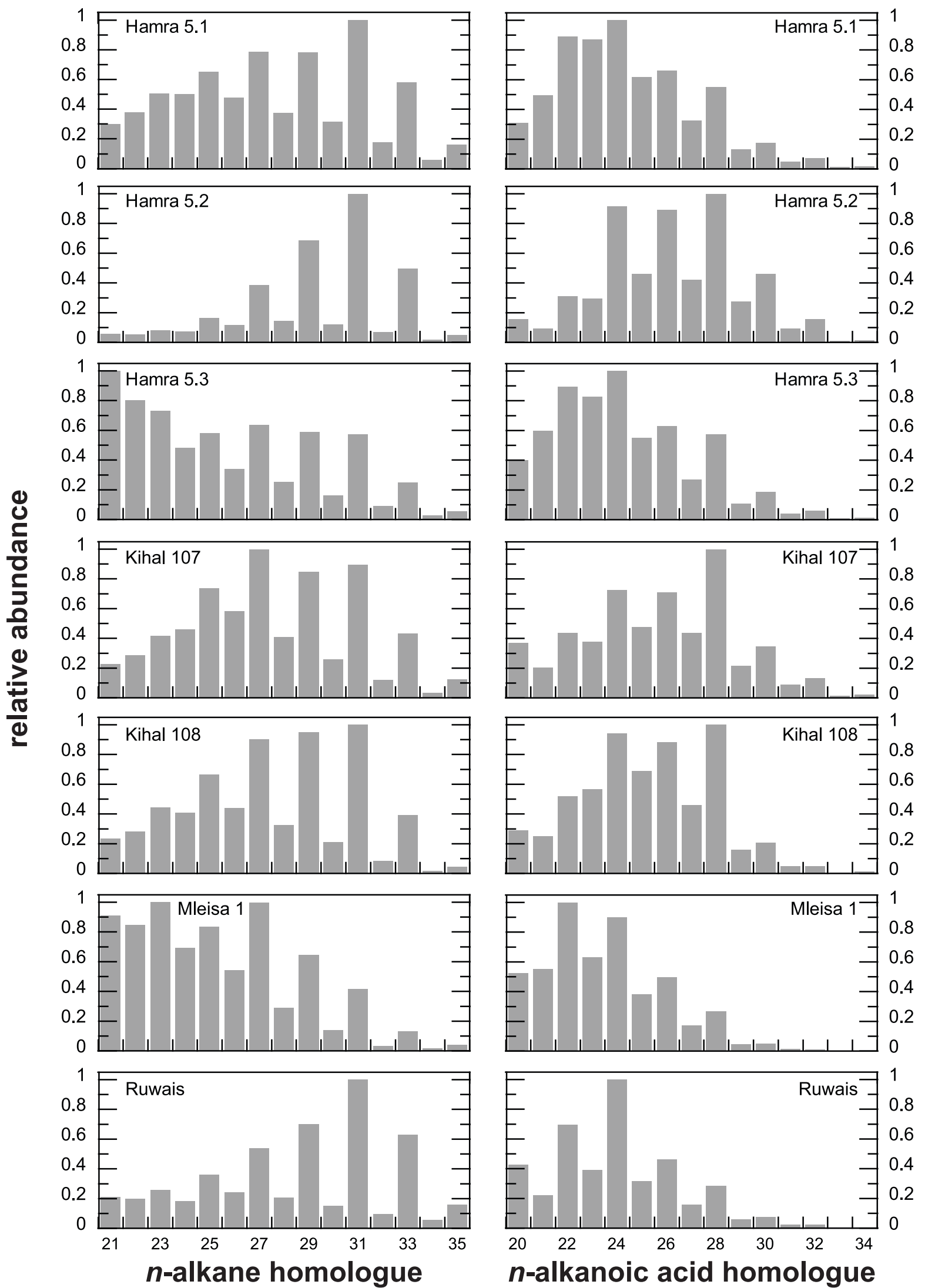

$n$-alkanoic acid homologue 
Fig 18.4

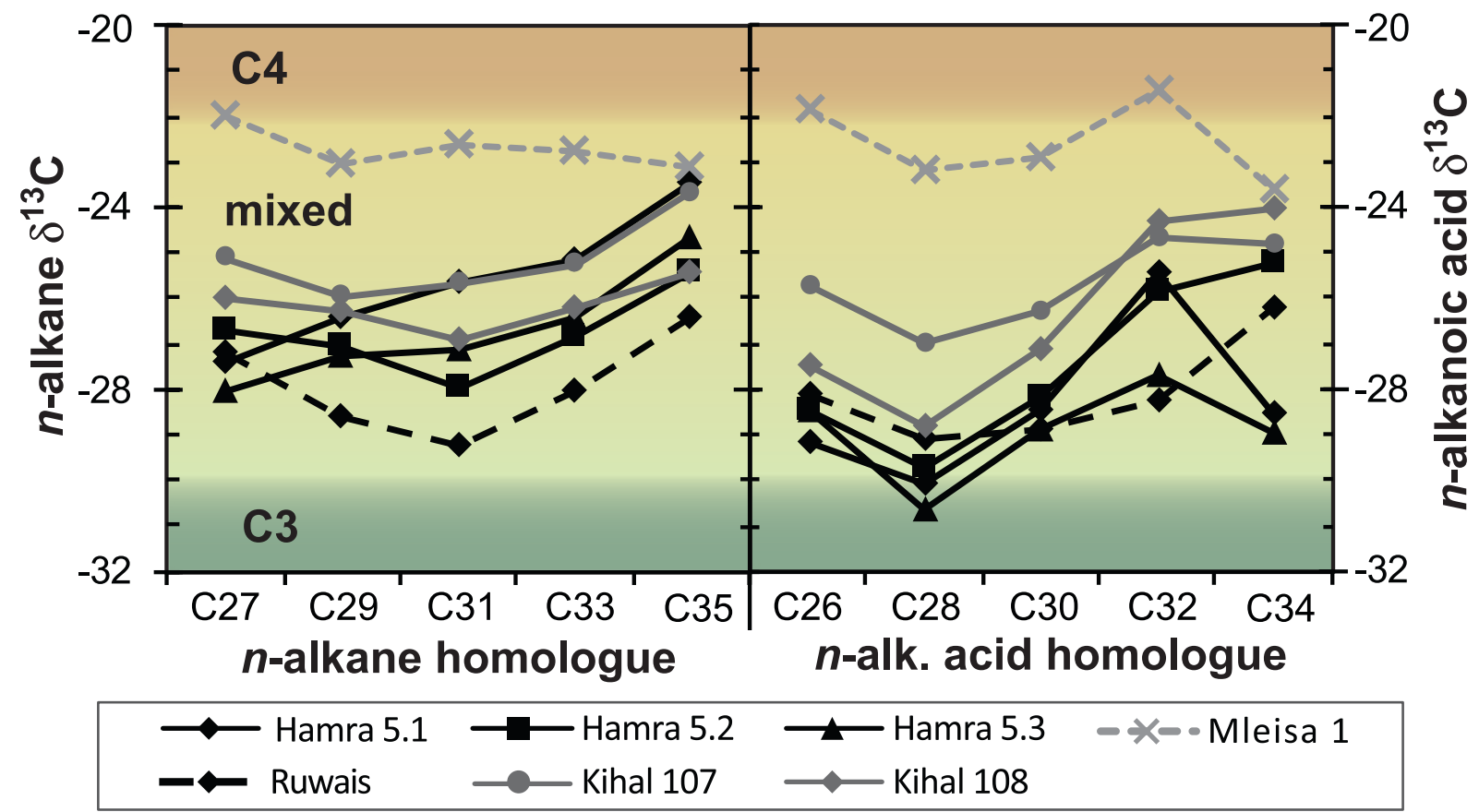


Fig 18.5
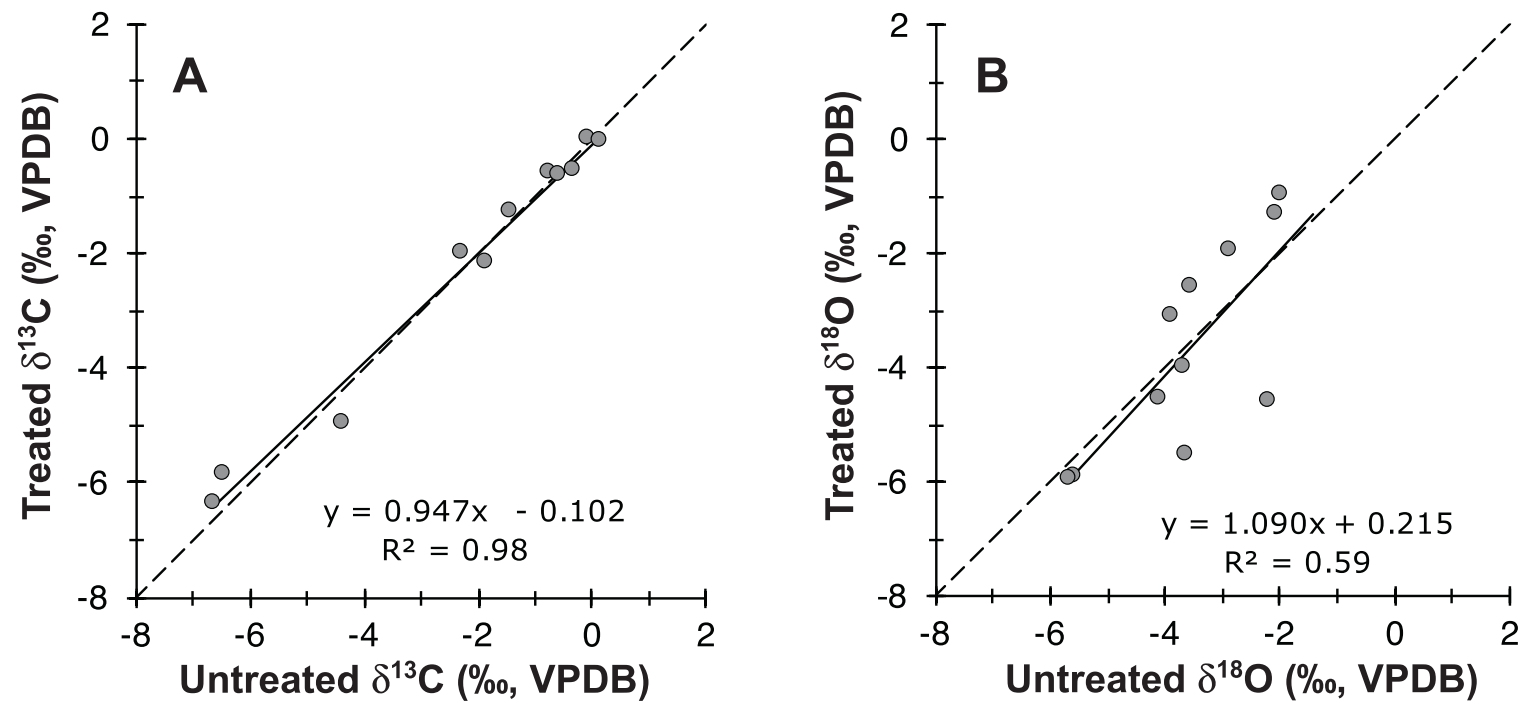
Fig 18.6

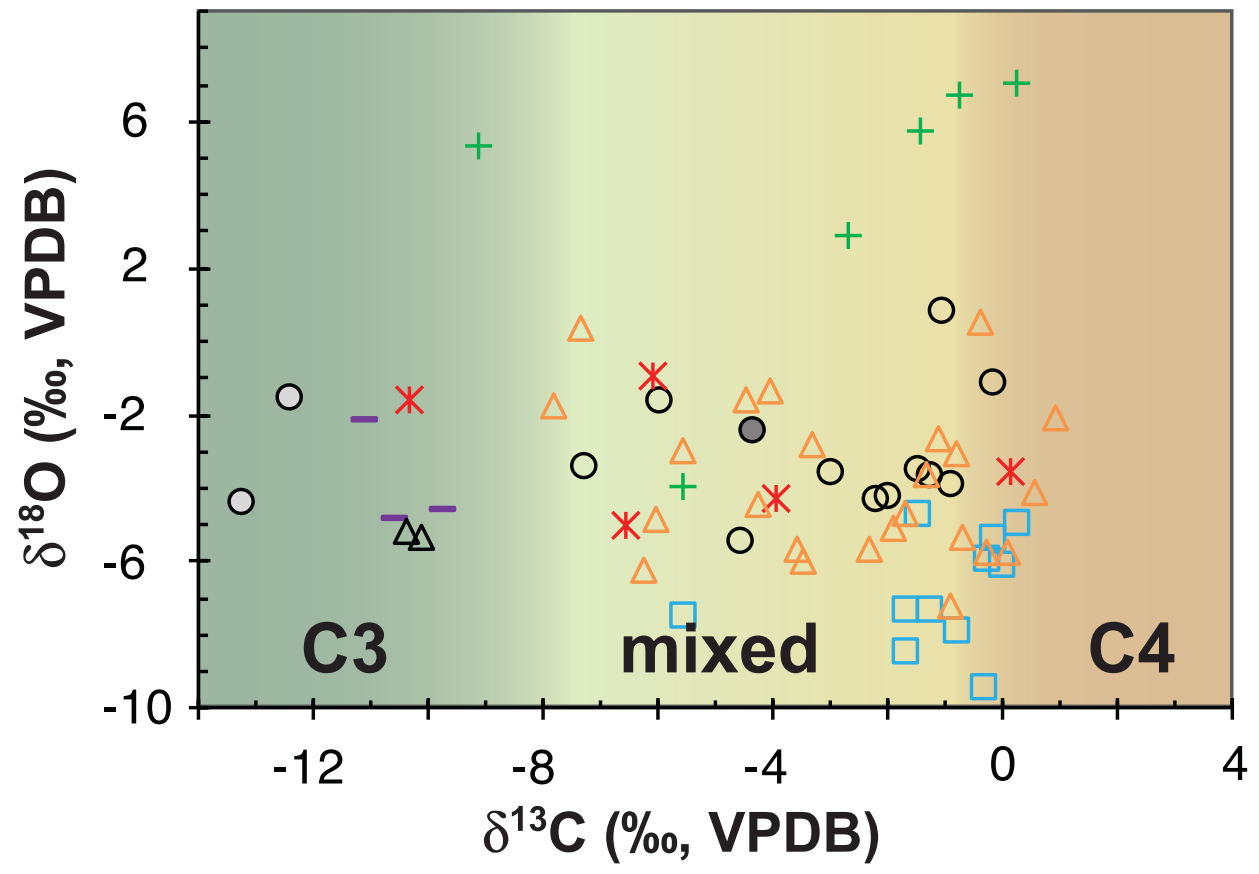

\begin{tabular}{|lll|}
\hline Artiodactyla & \multicolumn{1}{c}{ Proboscidea } & Perissodactyla \\
* Bovidae & O Deinotheriidae & $\triangle$ Equidae \\
+ Giraffidae & OElephantidae & $\triangle$ Rhinocerotidae \\
$\begin{array}{l}\text { Hippopotamidae } \\
\text { - OGomphotheriidae }\end{array}$ & \\
\hline
\end{tabular}


Fig 18.7

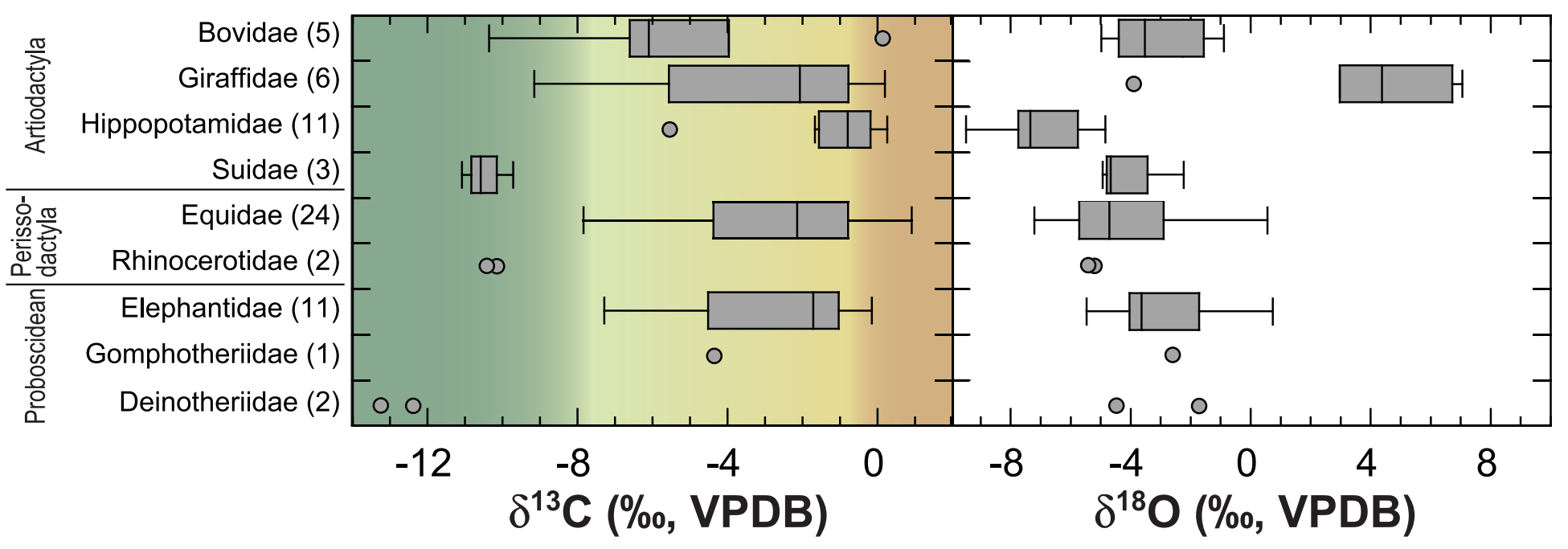


Fig 18.8

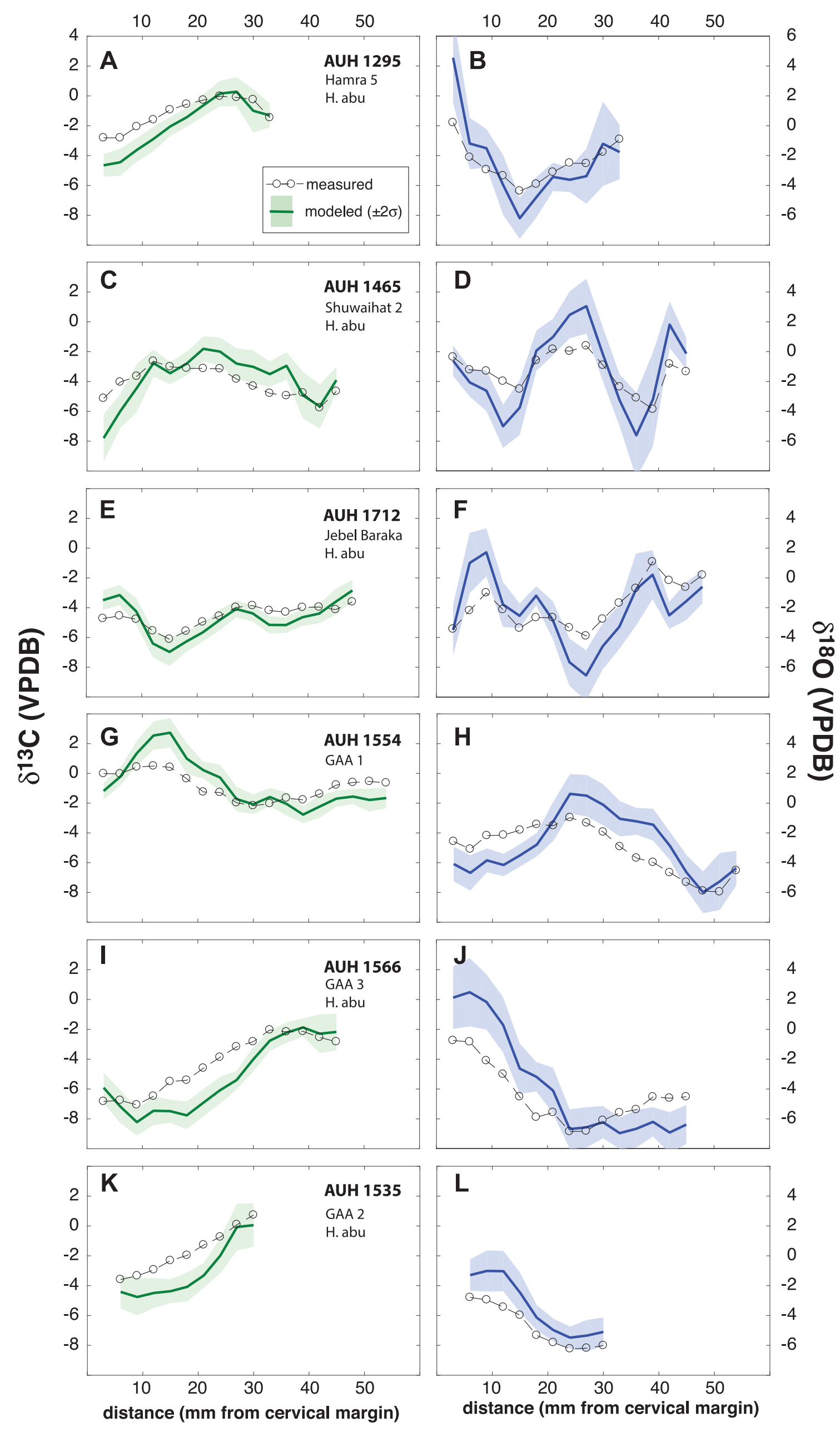


Fig 18.9

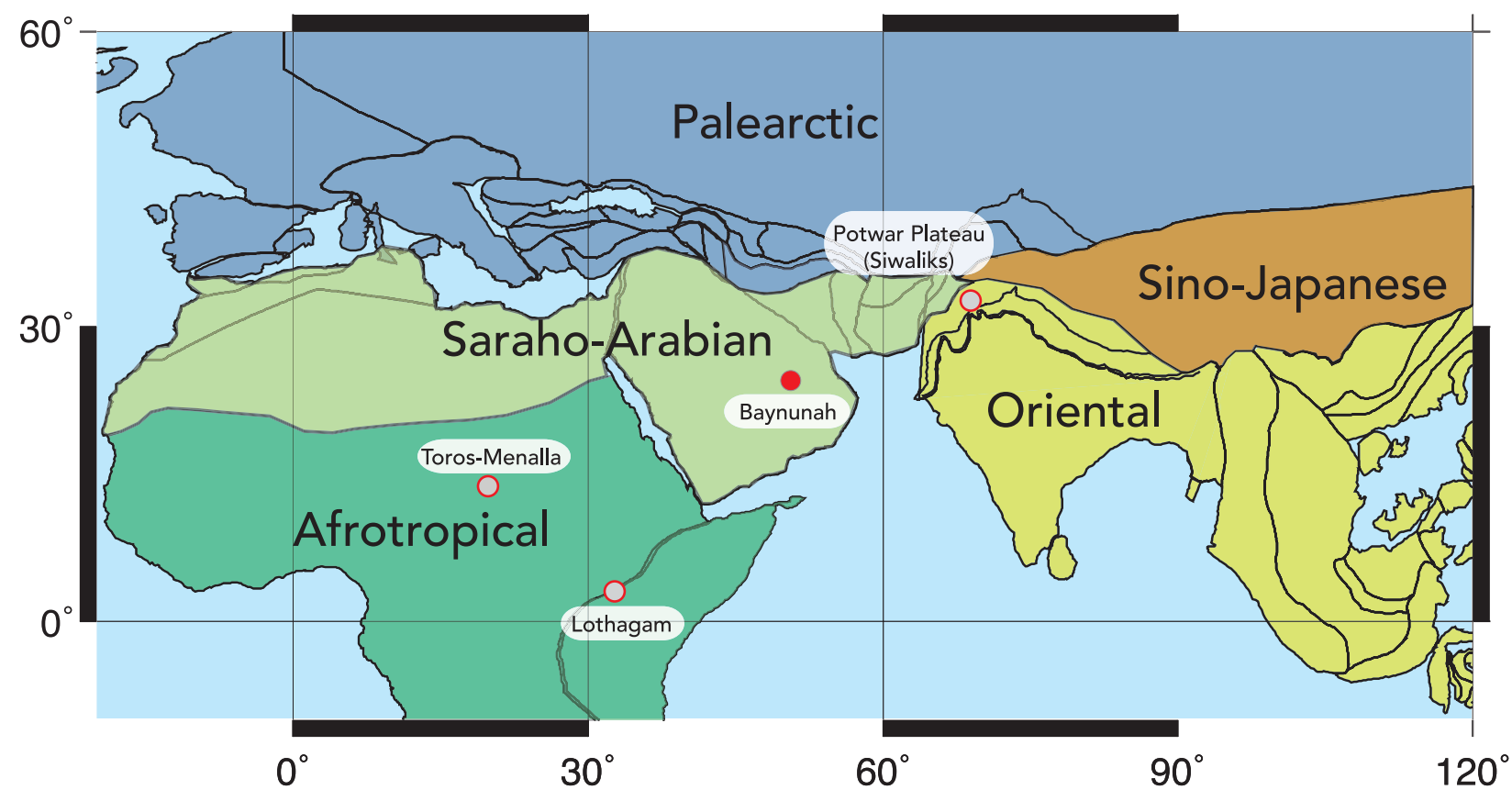


Fig 18.10

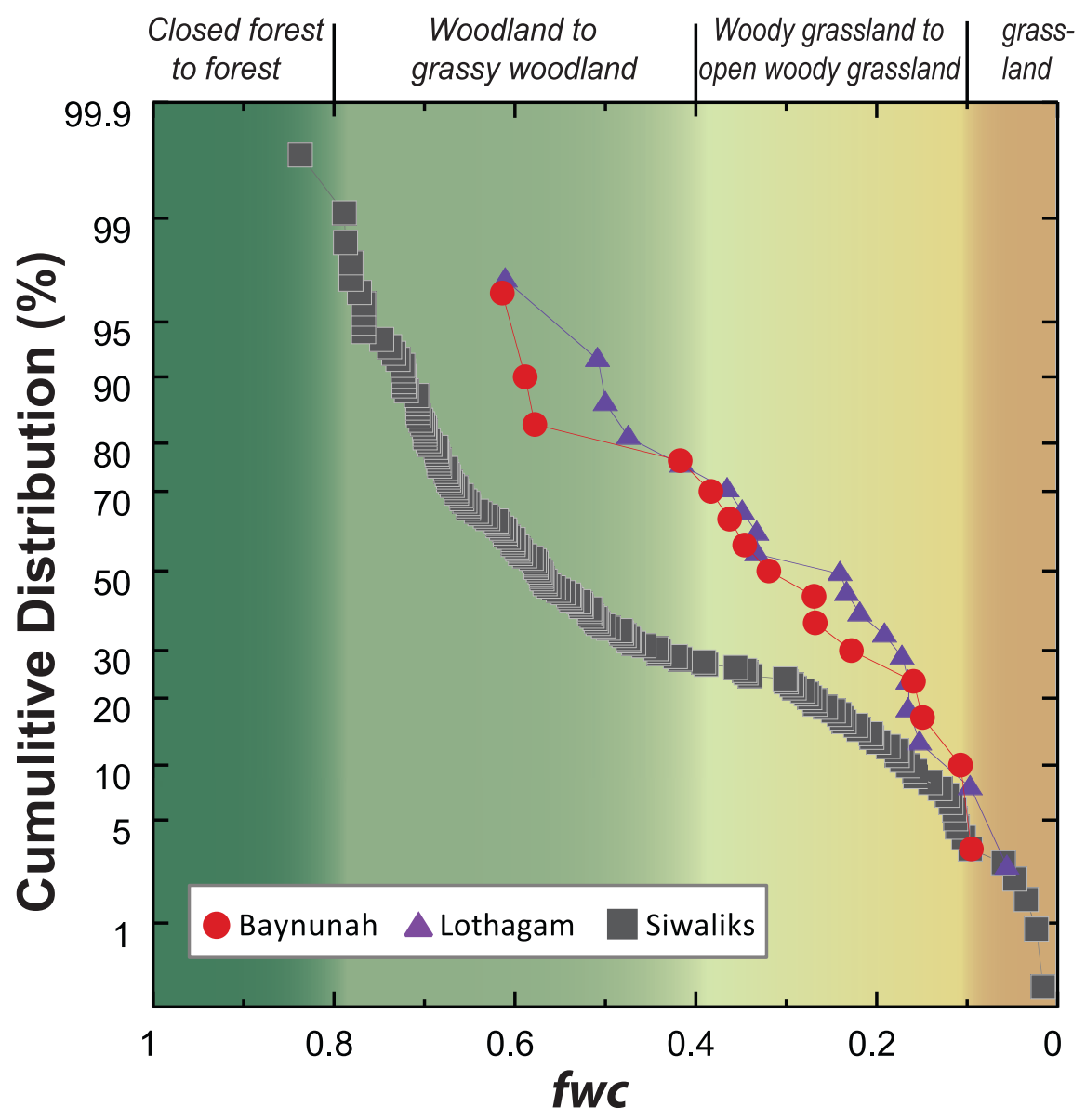




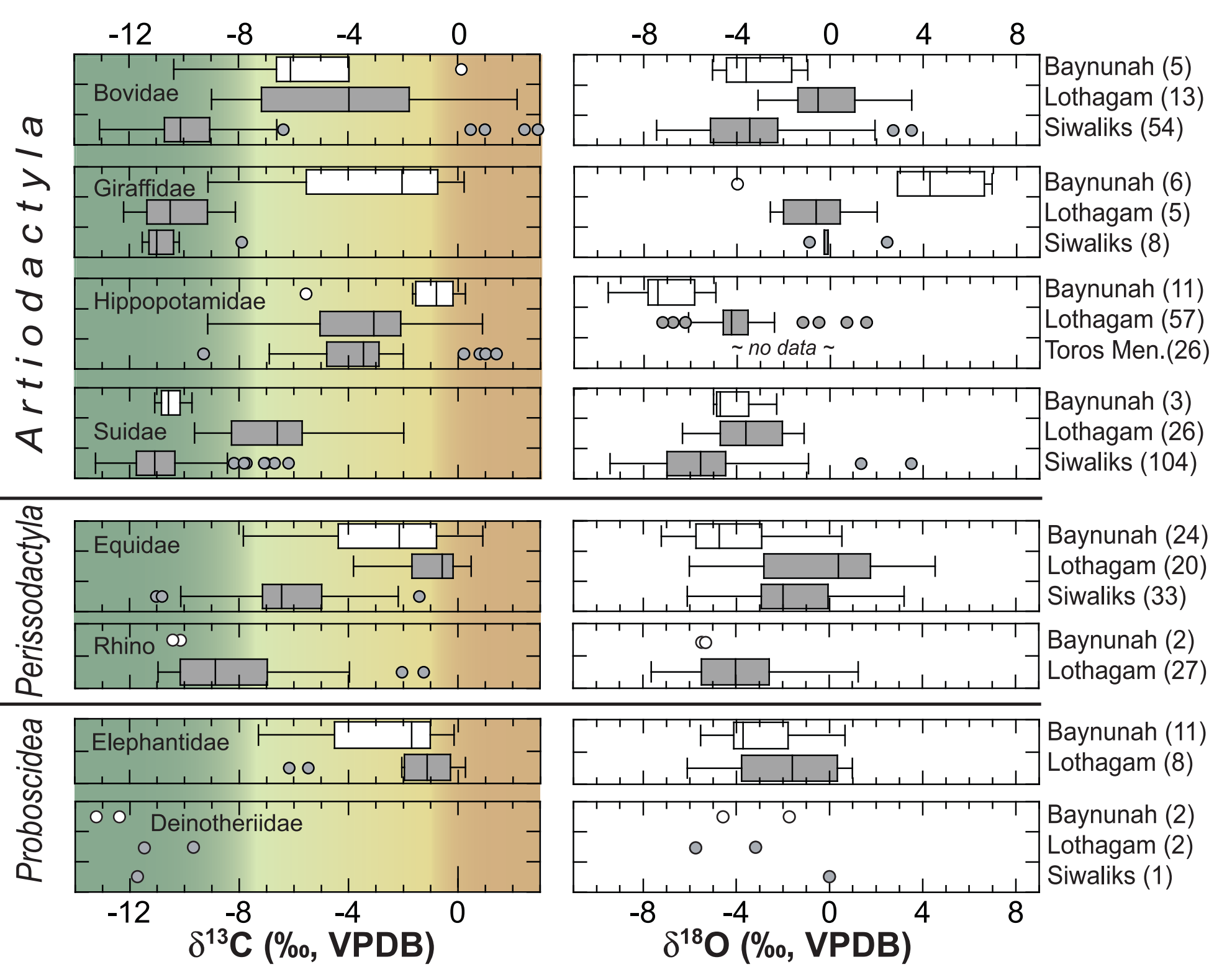

